\title{
Advancing Gender Equality and Social Inclusion
}

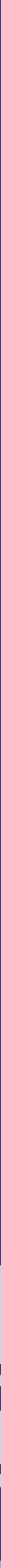




\section{About the FTA Highlights series}

This publication is part of a series that highlights the main findings, results and achievements of the CGIAR Research Program on Forests, Trees and Agroforestry (FTA), from 2011 to 2021 (see full list of chapters on the last page).

FTA, the world's largest research for development partnership on forests, trees and agroforestry, started in 2011. FTA gathers partners that work across a range of projects and initiatives, organized around a set of operational priorities. Such research was funded by multiple sources: CGIAR funders through program-level funding, and funders of bilateral projects attached to the programme, undertaken by one or several of its partners. Overall this represented an effort of about 850 million USD over a decade.

The ambition of this series is, on each topic, to show the actual contributions of FTA to research and development challenges and solutions over a decade. It features the work undertaken as part of the FTA program, by the strategic partners of FTA (CIFOR-ICRAF, The Alliance of Bioversity and CIAT, CATIE, CIRAD, Tropenbos and INBAR) and/or with other international and national partners. Such work is presented indifferently in the text as work "from FTA" and/ or from the particular partner/organization that led it. Most of the references cited are from the FTA program.

This series was elaborated under the leadership of the FTA Director, overall guidance of an Editorial Committee constituted by the Management Team of FTA, support from the FTA Senior Technical Advisor, and oversight of the FTA Independent Steering Committee whose independent members acted as peer-reviewers of all the volumes in the series.

FTA HIGHLIGHTS OF A DECADE 2011-2021

Advancing Gender Equality and Social Inclusion

(C) 2021 The GGIAR Research Program on Forests, Trees and Agroforestry (FTA)

Content in this publication is licensed under a Creative Commons Attribution 4.0

International (CC BY 4.0), http://creativecommons.org/licenses/by/4.0/

DOI: $10.17528 /$ cifor/008225

Elias M, Paez Valencia AM, Ihalainen M, Monterroso I. Advancing Gender Equality and Social Inclusion. FTA Highlights of a Decade 2011-2021 series. Highlight No.15. Bogor, Indonesia: The CGIAR Research Program on Forests, Trees and Agroforestry (FTA).

CGIAR Research Program on Forests, Trees and Agroforestry

GIFOR Headquarters

Jalan CIFOR

Situ Gede, Sindang Barang

Bogor Barat 16115 Indonesia

$\mathrm{T}+62-251-8622-622$

E cgiarforestsandtrees@cgiar.org

foreststreesagroforestry.org

We would like to thank all funding partners who supported this research through their contributions to the CGIAR Fund. For a full list of the 'CGIAR Fund' funding partners please see: http://www.cgiar.org/ ourfunders.

Any views expressed in this publication are those of the authors. They do not necessarily represent the views of The CGIAR Research Program on Forests, Trees and Agroforestry (FTA), the editors, the authors' institutions, the financial sponsors or the reviewers.

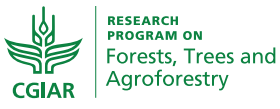




\section{Advancing Gender Equality and Social Inclusion}

Authors: Marlène Elias, Ana Maria Paez Valencia,

Markus Ihalainen, Iliana Monterroso

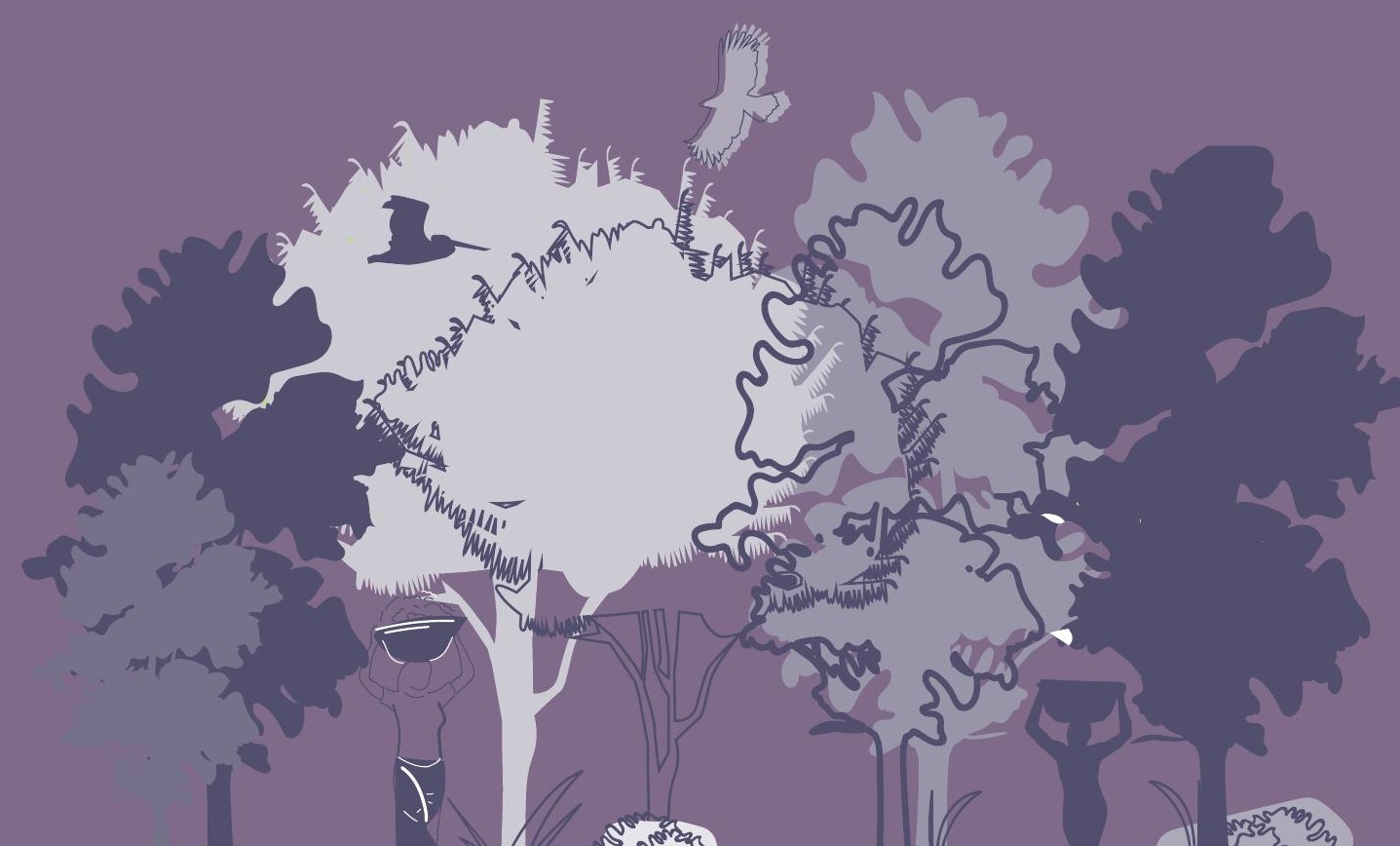




\section{Editorial and publication team}

\section{Editorial Committee of the Highlights Series}

Vincent Gitz (Chairperson of the Editorial Committee), Michael Allen Brady, René Boot, Marlène Elias, Ramni H. Jamnadass, Christopher Kettle, Yanxia Li, Christopher Martius, Alexandre Meybeck, Peter A. Minang, Fergus Sinclair, Plinio Sist and Eduardo Somarriba.

\section{Independent Steering Committee of FTA}

Anne-Marie Izac (Chairperson of the ISC), René Boot, Susan Braatz, Linda Collette, Vincent Gitz, Florencia Montagnini, Richard Stanislaus Muyungi, Robert Nasi and Stephan Weise.

\section{FTA Director}

Vincent Gitz

\section{FTA Highlights Support Team}

Technical and scientific editing: Alexandre Meybeck, FTA senior technical advisor Coordination of publication process, editing and lay-out: Fabio Ricci, FTA communications' coordinator Coordination of the peer-review process: Monika Kiczkajlo, FTA program manager Language editing and referencing: Patricia Halladay, consultant Lay-out and design: Dharmi Bradley, consultant

\section{Acknowledgements}

Thanks are due to Haley Zaremba for her support with copyediting and referencing.

We gratefully acknowledge Anne-Marie Izac, Alexandre Meybeck, Vincent Gitz for their constructive review and feedback on an earlier version of the manuscript. 


\section{Table of contents}

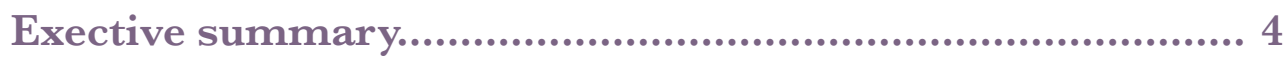

1. Introduction............................................................................. 5

2. Integrating gender in FTA................................................. 7

3. How the research is carried out..........................................13

4. Outreach and outcomes.......................................................... 32

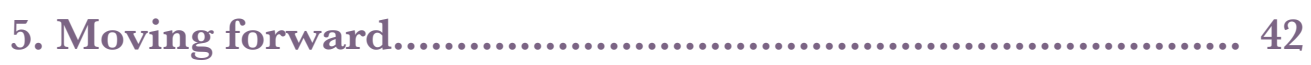

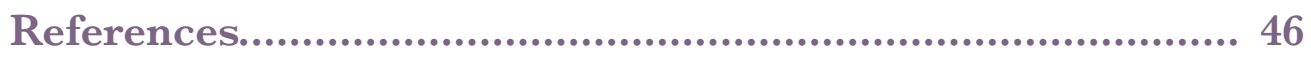

\section{List of acronyms}

CBD Convention on Biological Diversity

CIAT International Centre for Tropical Agriculture

CIFOR Center for International Forestry Research

CRP GGIAR Research Program

FAO Food and Agriculture Organization

FTA CGIAR Research Program on Forests, Trees and Agroforestry

GEF Global Environment Facility

ICRAF World Agroforestry Centre

IFAD International Fund for Agricultural Development

ISPG Independent Science and Partnership Council

IUFRO International Union of Forestry Research Organizations

PEN Poverty-Environment Network

PES Payments for ecosystem services

REDD+ Reducing Emissions from Deforestation and Forest Degradation

RSPO Roundtable on Sustainable Palm Oil

SDGs Sustainable Development Goals

UNFCGG United Nations Framework Convention on Climate Change

WFP World Food Programme 


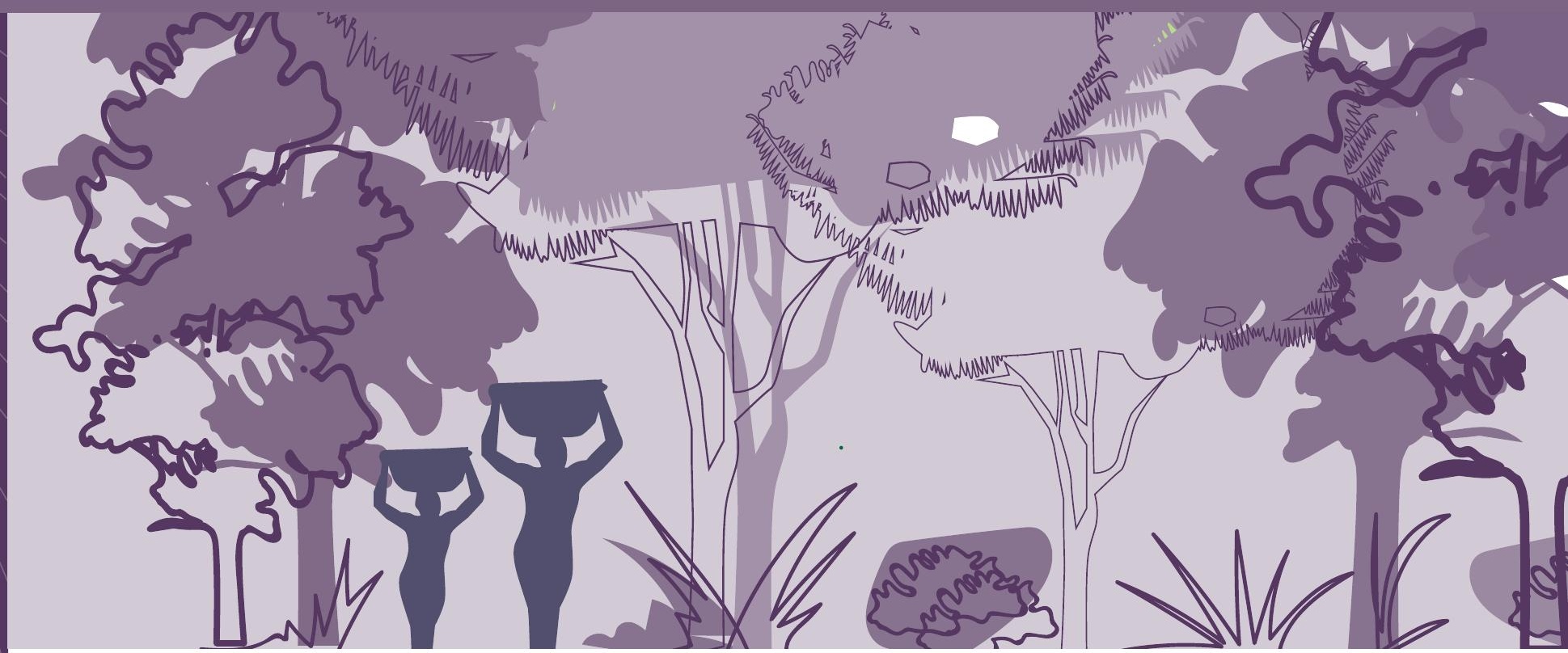

\section{Executive summary}

This publication reflects on FTA's decade-long journey to advance gender equality in forest, tree and agroforestry landscapes to glean lessons and continue building on the achievements of the Program. The discussion follows the two interconnected and mutually-reinforcing strands detailed in the FTA Gender Strategy (2013) and Revised Research Agenda and Action Plan (2020) to achieve this goal. The first strand focuses on the research itself and the partnerships and processes that allow it to translate into outcomes and impacts of various types. The second strand, which this publication tackles at the beginning, focuses on efforts to strengthen gender integration within FTA: generating the necessary capacities, mindsets, and enabling environment to integrate gender across the FTA research portfolio, processes and structures, and to generate quality gender-focused research. The publication moves from local-level changes to high-level discourses and agendas to examine the strategies that enabled change across these scales, critically reflecting on the challenges encountered along the way. Finally, priorities are considered and an agenda for future gender research is proposed, one that can contribute to the creation of equitable, inclusive and sustainable forest, tree and agroforestry landscapes. 


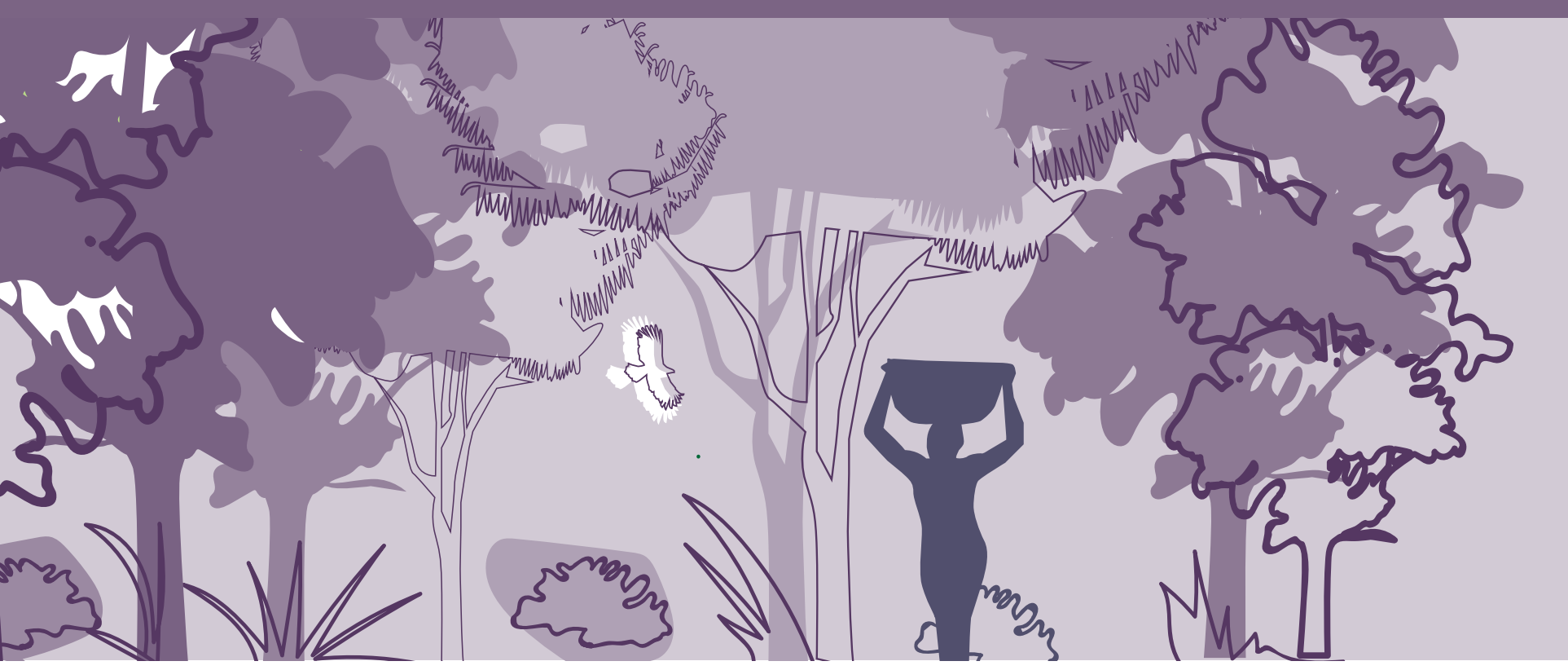

\section{Introduction}

The GGIAR Research Program (GRP) on Forests, Trees and Agroforestry (FTA) focuses on enhancing livelihoods through forest, tree, and agroforestry systems, and on enhancing and protecting natural resources. With an estimated 1.6 billion people living in or near forests (Newton et al. 2020), many of whom depend on forests and trees - including trees on farms - for their livelihoods, forest, tree and agroforestry systems have much to contribute to addressing inequalities between women and men, and empowering disadvantaged women in ways that contribute to sustainable landscapes. For the FTA program, with a key focus on policies, institutions and governance, gender inequalities present structural barriers to the change that is needed to support sustainable and equitable development solutions in landscapes and along value chains. Hence, concerns for gender equality have been carefully integrated into FTA. In addition to conducting research specifically on gender and on women's and men's empowerment, FTA has mainstreamed gender throughout its research portfolio, aiming to make transformative change at multiple scales, from local to global levels.

FTA's Gender Strategy (CIFOR 2013d) was one of the first CRP gender strategies to be approved by the Independent Science and Partnership Council and the Consortium Office. It outlines the critical roles that both women and men play in managing forests, agroforestry and tree resources across the developing world, and the importance for research to add more weight to knowledge generation and transmission that can help redress gender inequities in resources and benefits. It recognizes the need to achieve greater gender equity as a goal in its own right, and as a means for more effective natural resource management. 
FTA's research agenda has evolved since its inception, and so too has its portfolio of gender and social inclusion research. A revised research agenda and action plan (CGIAR FTA 2020) draws on a tradition of quality gender work within FTA centres and complemented FTA's original Gender Strategy (CIFOR 2013d). It reflects the evolution of the program into areas where gender is key, such as increased emphasis on international policy processes, and on sustainable value chains and finance. It also reflects thematic and methodological developments in gender research and practice, and increased the focus on the links between gender and generation (including youth issues) as well as efforts to make FTA's research increasingly transformative. These two documents have been a roadmap for FTA's gender research over the years.

This publication reflects on FTA's nearly decade-long journey to advance gender equality in forest, tree and agroforestry landscapes to glean lessons and build on the achievements of the program. The discussion follows FTA's Theory of Change related to gender and inclusion, comprising two interconnected and mutually reinforcing strands to achieve this goal (Figure 1).

This publication reviews local-level changes and high-level processes and agendas, examining the strategies that enabled change and critically reflecting on the challenges encountered along the way. It also sets out an agenda for future gender research that can build on the momentum FTA has achieved to further contribute to the creation of equitable, inclusive, and sustainable forest, tree and agroforestry landscapes.

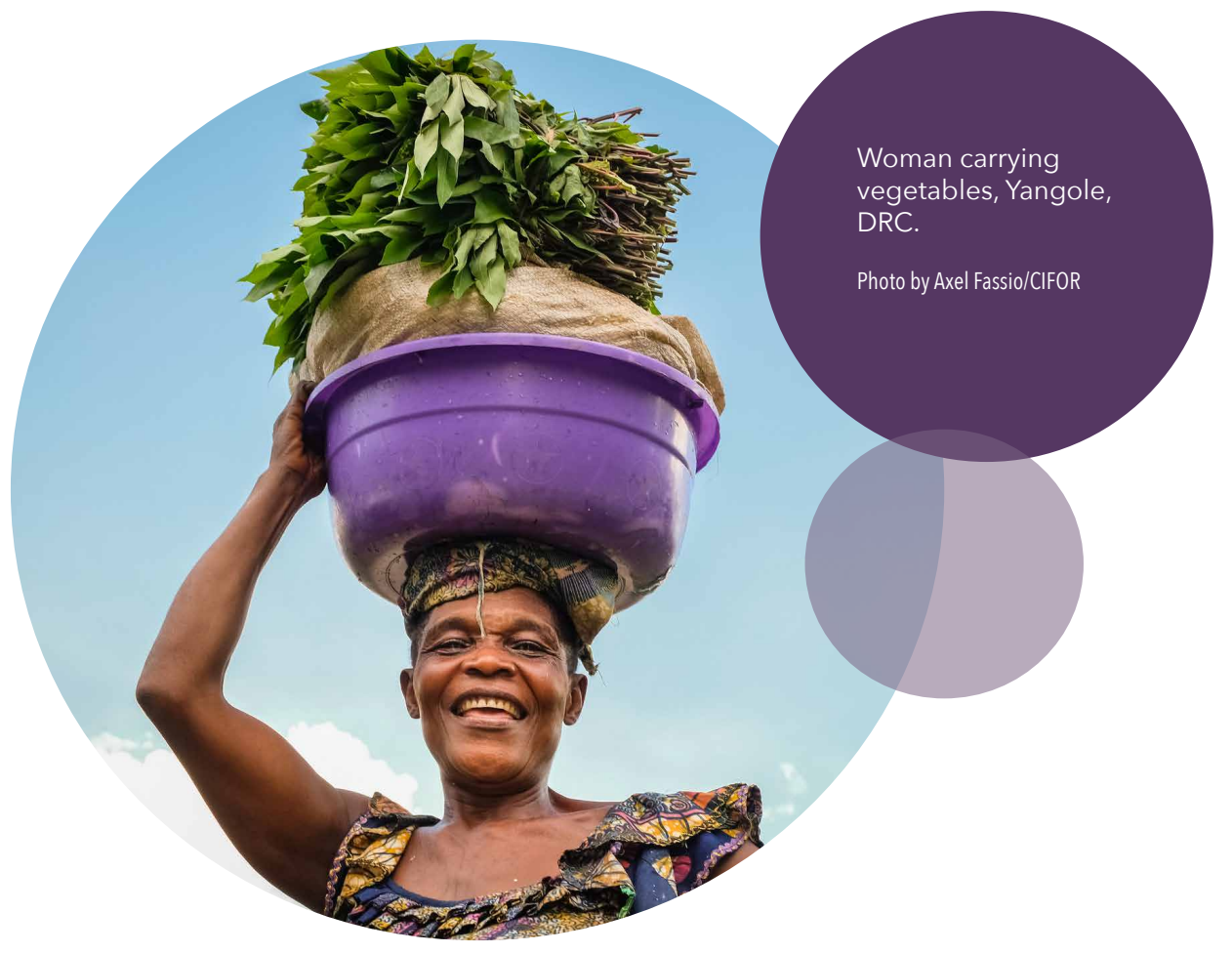




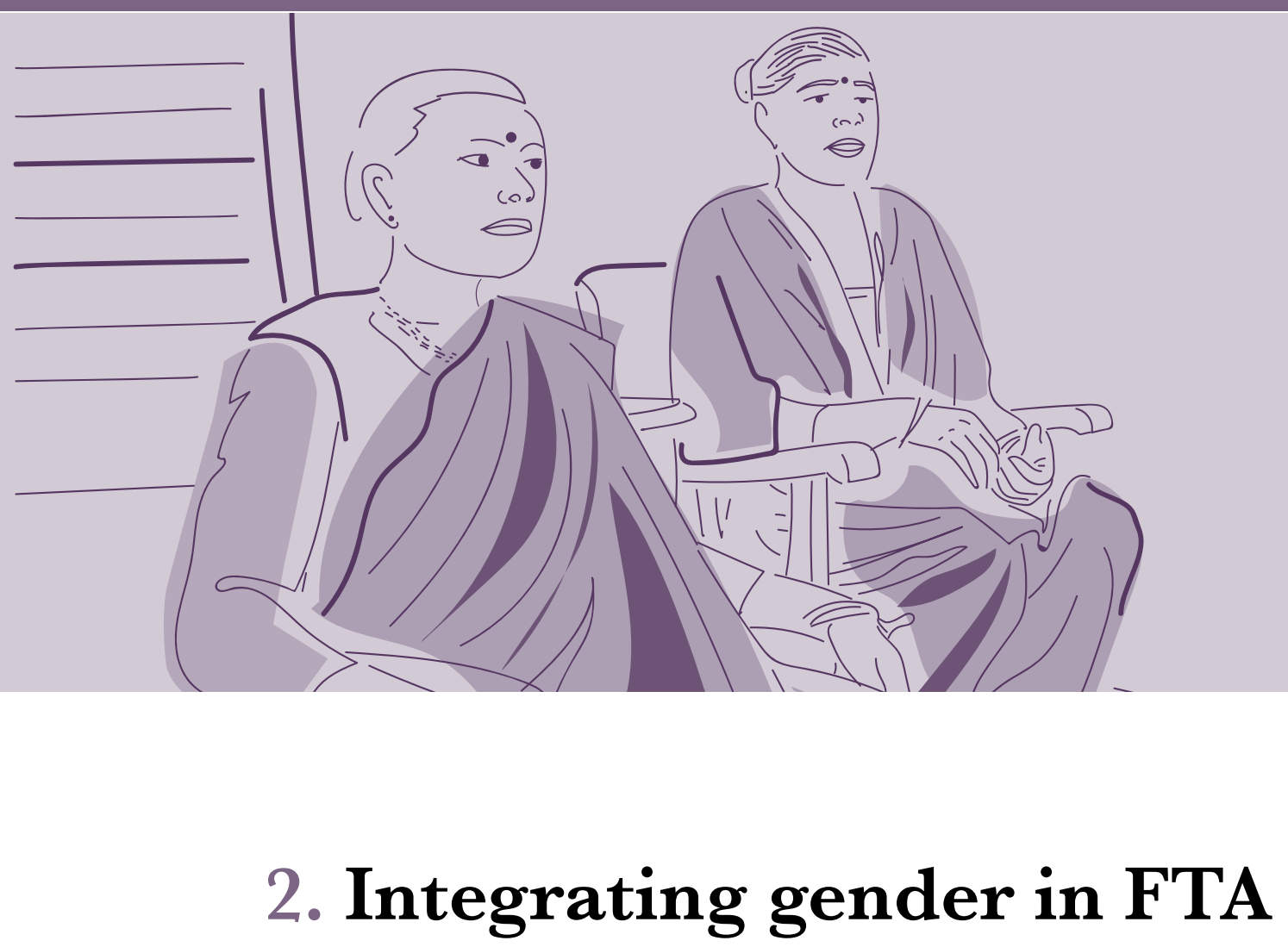

\subsection{Foundational moments}

FTA's commitment to addressing gender equality has been recognized in numerous assessments and evaluations since its inception. In its commentary on the first phase proposal of FTA, the Independent Science and Partnership Council (ISPG 2011,3) notes that FTA thoroughly and thoughtfully addresses gender "both in terms of the gender-specific aspects of the research questions addressed, and also as a major cross-cutting theme," going "beyond the research stage to recognize the need to ensure that outputs get translated into gender-positive outcomes and on to impacts on the ground" (ibid.). FTA's gender research builds on CGIAR work that preceded the CRP, yet pursuit of this research as a coherent and coordinated body of work across contributing centres grew with the CRP itself. In 2012, as the CRPs were launched, FTA developed a strategy for gender integration and research that included an accountability framework, a substantial budget for gender research and integration, and an envisioned pathway for achieving impacts on gender relations, with clear goals, outcomes and indicators (CIFOR 2013a, b). The strategy emphasized knowledge-sharing on gender in relation to FTA's thematic/programmatic research areas (Flagship Programs) and genderresponsive monitoring and evaluation for adaptive learning. Moreover, it called for a gender team to oversee its implementation.

${ }^{1}$ The CRP had two phases: Phase I from 2012 to 2016 and Phase II from 2017 to 2021. 


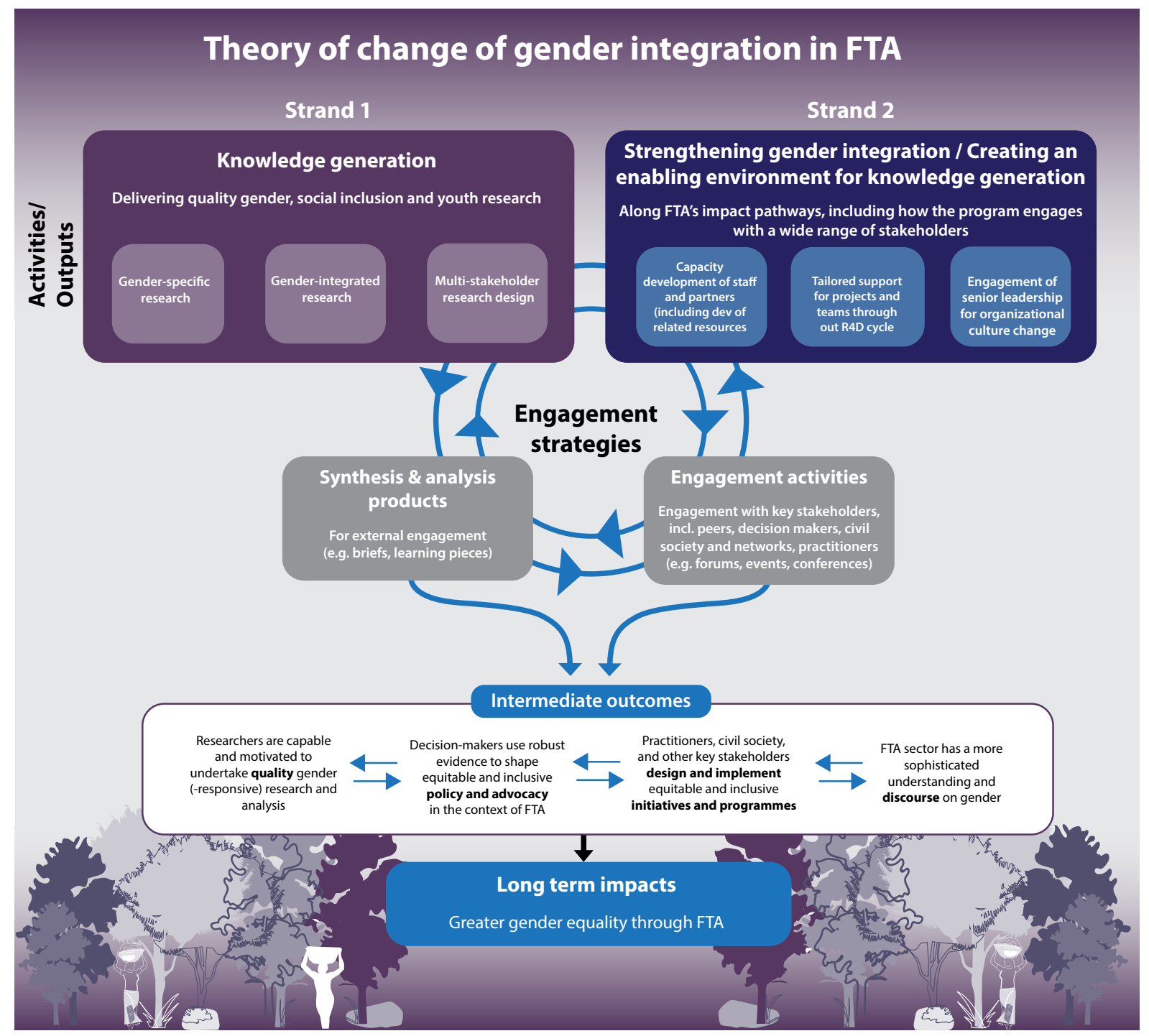

Figure 1. Theory of change of gender integration in FTA. Source: CGIAR FTA 2020

The FTA Gender Strategy (CIFOR 2013d), and later, the Revised Agenda and Action Plan (CGIAR FTA 2020) followed a multi-pronged approach, characterized by two main, mutually supportive strands of work (Figure 1). One strand centres on knowledge generation and delivering quality gender and social inclusion research. The other strand, which is discussed first in this publication, focuses on strengthening gender integration in FTA's institutional structures: generating the necessary capacities and mindsets and the enabling environment to integrate gender across FTA's research and processes and structures, and to generate quality gender-focused research. This other strand emphasizes engagement with a wide range of stakeholders in order to remain relevant and demand-driven and to enhance impacts. The two strands interact; the enabling environment 
(Strand on the right), which nurtures researcher capacities and motivations to undertake gender-responsive research, underpins knowledge generation and impacts (Strand on the left), and FTA research feeds into the resources and approaches in FTA's gender integration processes.

Members of FTA's gender team were gender specialists from four of FTA's managing partners: Bioversity International, International Centre for Tropical Agriculture (CIAT), Genter for International Forestry Research (CIFOR), and World Agroforestry Centre (ICRAF). Gender team members worked and liaised with other FTA scientists and partners, and provided them with sustained, tailored support, working collaboratively to produce gender research, outreach and communications outputs, and to engage stakeholders on gender and natural resource management. Between 2013 and 2021, the gender team had between four and seven members, with dedicated time to support gender integration. Annual work plans were discussed and formulated within the team, with inputs from FTA's thematic flagship leaders and gender researchers. Rotational leadership, vested in the Gender Research Coordinator, ensured that responsibilities, opportunities and budgets were shared among gender team members. One member served as a focal point for each Flagship Program, to contribute to the preparation of gendersensitive program workplans. The Independent Evaluation Arrangement's (IEA) Evaluation of Gender in CGIAR (CGIAR-IEA 2017, 71) notes this as a good practice. Indeed, the inter-centre coordination team, high-level FTA support, and funding for gender integration and research for each FTA centre proved to be critical components of what would become a successful gender integration strategy for the CRP (CGIAR-IEA 2017; Charles Darwin University 2019).

\subsection{Changing mindsets}

FTA's gender research and actions sought to effect changes in capacities to integrate gender considerations within FTA itself, and in the forestry and agroforestry sectors more generally, and to translate these changes into enhanced gender equality on the ground. This was achieved in five primary ways:

1. creating tools and resources for integrating gender into project design;

2. strengthening capacities for gender analysis and gender-responsive research through workshops and training;

3. establishing a Gender Research Fellowship Programme;

4. strategic positioning of gender research within the Flagship Programs; and holding interdisciplinary dialogues within FTA. 
Since the CRP's inception, the gender team and other gender scientists have developed more than 20 general tools and resource materials (as well as thematically-focused ones, discussed below) to support gender integration, for the use of FTA scientists and other stakeholders (researchers, practitioners, policymakers) in forestry and agroforestry. These tools ranged from guides and analytical frameworks describing the various ways in which gender relates to forestry research (Manfre and Rubin 2012; CIFOR 2013c; Colfer 2013), to strategies, methods and tools for conducting gender-responsive research and communications (CIFOR 2013b; Elias 2013a,b; Catacutan et al. 2014; Elias and Hermanowicz 2016; Colfer et al. 2018). ${ }^{2}$ Resource materials ${ }^{3}$ took multiple forms and were written in accessible language for non-specialists. Some were translated into several languages. On the whole, they have been highly used and cited not only within FTA, but throughout CGIAR and beyond, by a range of researchers and practitioners working on natural resources management.

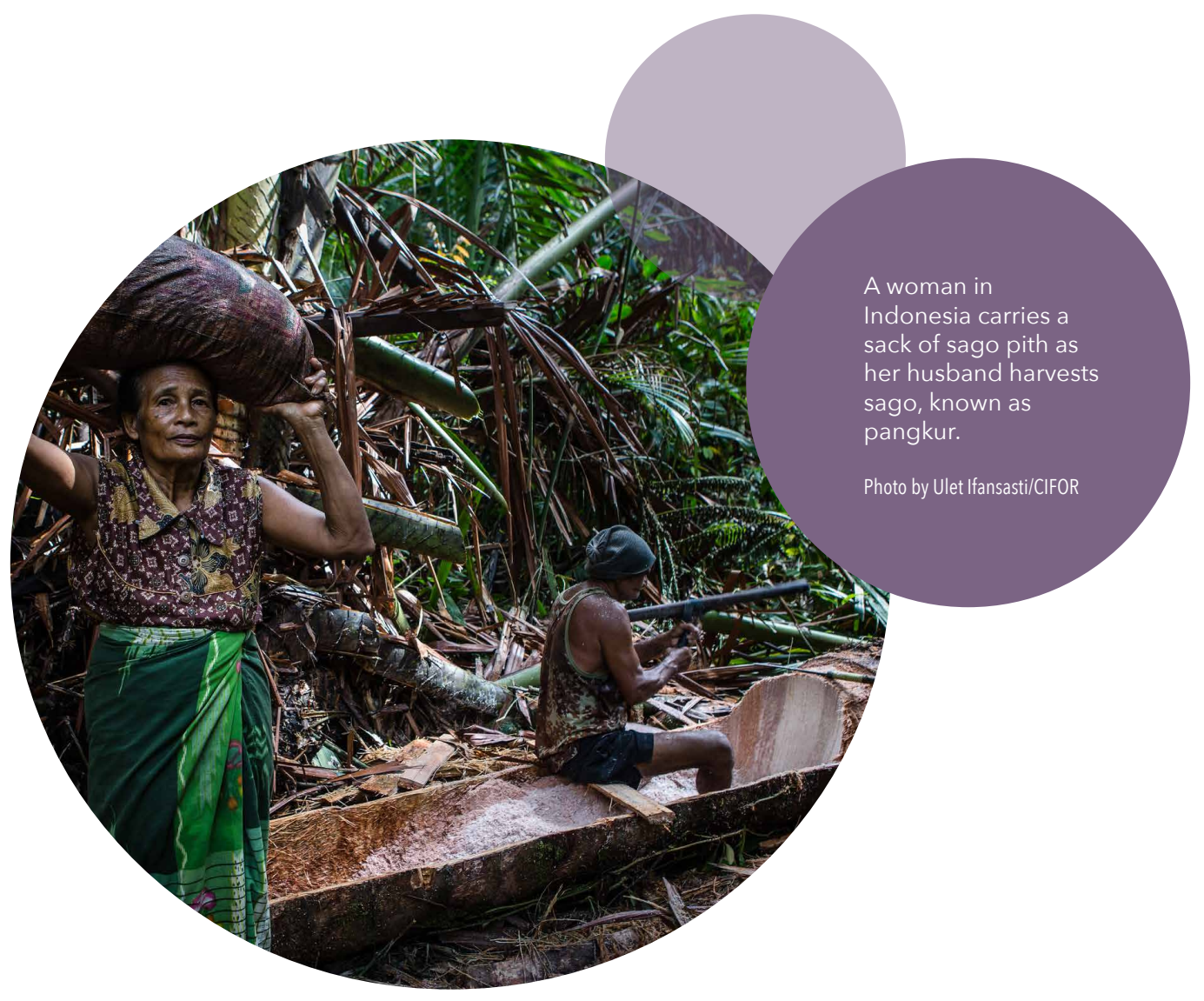

\footnotetext{
${ }^{2}$ For example, one tool - the Gender Equality in Research Scale (GEIRS; see CGIAR FTA 2019 and Paez et al. 2019) was designed to support project design and monitoring and learning for gender integration, and was rolled out across the FTA portfolio in 2015. This enabled research teams to identify strategies for achieving higher levels of gender integration, and the gender team to better direct its support within FTA by examining the distribution of projects along a continuum of gender integration.

${ }^{3}$ https://www2.cifor.org/gender/tools-manuals/.
} 
The gender team also conducted capacity-strengthening workshops and training for thousands of FTA scientists, partner organizations and other stakeholders in the forestry and agroforestry sectors. Like the tools produced, these were more basic and general at the beginning of FTA and increased in thematic sophistication throughout FTA's lifespan. Training was delivered according to skill level, and used a range of methods, from agent-based modeling and role-play games to surveys and more participatory approaches, drawing on the latest FTA research (Villamor et al. 2012; Basilio and Fernandez 2014; Elias et al. 2014; Villamor 2014). This training addressed various themes, ${ }^{4}$ such as forest landscape monitoring (e.g. Sentinel Landscapes - Rubin et al. 2013), forestry value chains, and tenure relations in Latin America.

In addition, FTA ran two phases ${ }^{5}$ of a Gender Research Fellowship Programme. Fellows were mentored by FTA gender specialists and integrated in project teams to spread learning out across the FTA portfolio. Fellows participated in learning workshops, wrote papers, ${ }^{6}$ including a special issue (Elias et al. 2017b), and participated in international conferences ${ }^{7}$ to strengthen their capacities. The Fellowship Programme created a community of practice on gender within FTA and enhanced the overall genderresponsiveness of the FTA portfolio (Thull et al. 2015).

Importantly, FTA strategically positioned its gender research within the Flagship Programs, so that key gender considerations could influence the direction of their research agendas. For each program, gender research questions were jointly developed by gender team members and the program leaders (Figure 2), ${ }^{8}$ and gender research activities were carried out in the programs' priority geographical areas, where partnerships could be leveraged to inform policy and practice. The GGIAR-IEA (2017) Evaluation of Gender in CGIAR acknowledges the value of this strong collaboration between the gender team and Flagship Program leads in setting priorities. Examples of this integration and alignment include technical workstreams dedicated to inclusive landscape governance and to inclusive value chains, finance and investments at the FTA Science Conference (2020), ${ }^{9}$ which included several contributions on gender.

\footnotetext{
${ }^{4}$ https://www.worldagroforestry.org/sites/default/files/Gender\%20cross-cutting\% $\% 20$ theme $\% 20$ newsletter $\% 20$ N. 1.pdf ${ }^{5}$ https://www.bioversityinternational.org/news/detail/round-two-of-the-gender-research-fellowship-programme-takes-offin-nairobi/

${ }^{6}$ https://blogarchiv.tropentag.de/node/638

${ }^{7}$ https://www.bioversityinternational.org/news/detail/case-studies-from-around-the-globe-show-that-gender-responsiveparticipatory-research-is-the-way-to/

${ }^{8}$ The five Flagship Programs to which these questions relate, in Phase 2 of FTA, are: 1. Tree genetic resources to bridge production gaps and promote resilience; 2. Enhancing how trees and forests contribute to smallholder livelihoods; 3. Sustainable global value chains and investments for supporting forest conservation and equitable development; 4 . Landscape dynamics, productivity and resilience; and 5. Climate change mitigation and adaptation opportunities in forests, trees and agroforestry.

${ }_{9}^{9}$ https://www.foreststreesagroforestry.org/fta-2020-science-conference-forests-trees-and-agroforestry-science-for-transformational-change/
} 


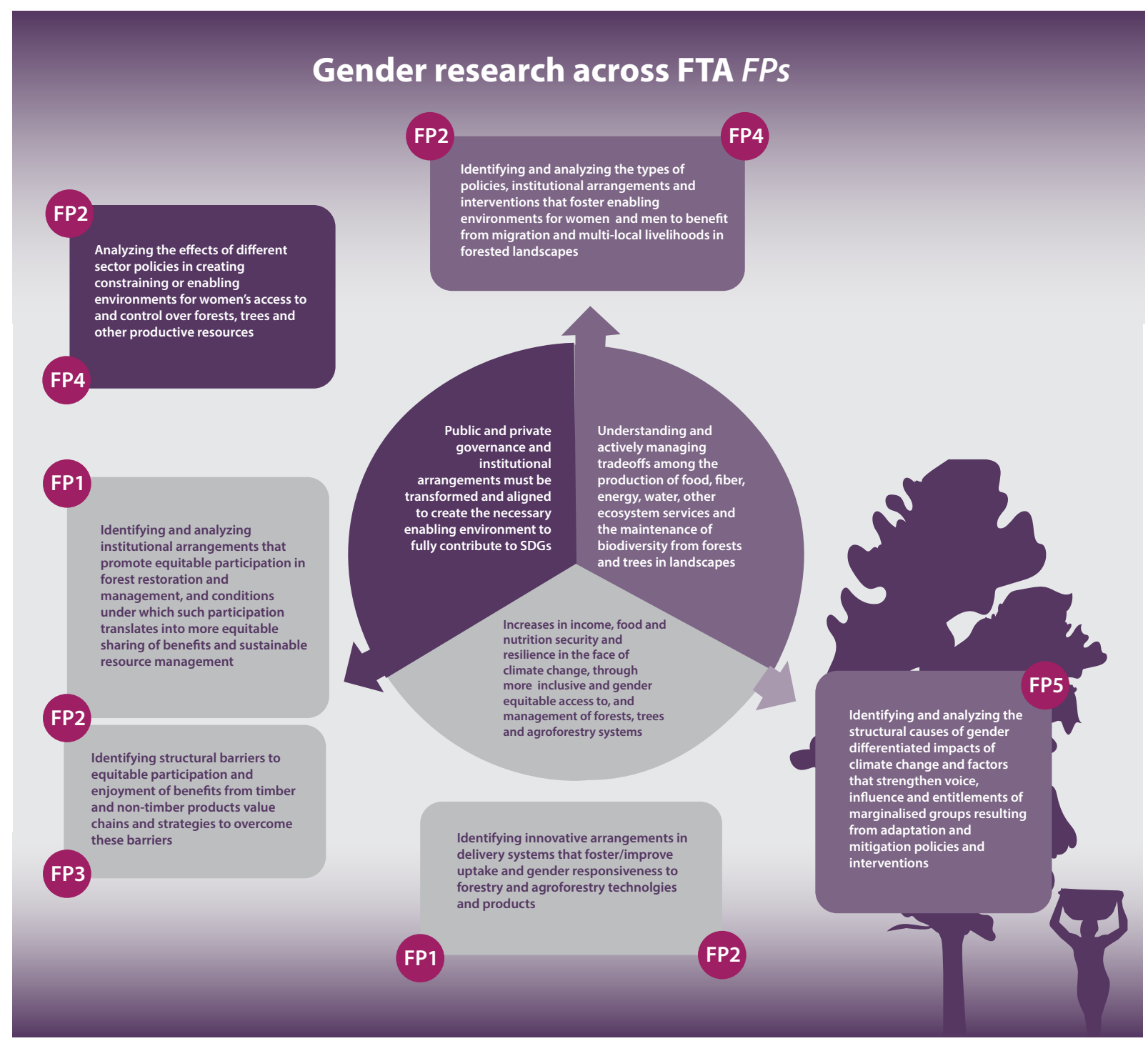

Figure 2. Gender research across FTA FPs. Source: CGIAR FTA 2020

The gender team also worked closely with colleagues across FTA's Flagship Programs to engage in interdisciplinary dialogues and to ground gender research in specific forest, tree and agroforestry issues, providing tailored support for gender integration. Gender scientists were embedded in FTA proposals and led gender research-focused proposals, and gender served as a platform for convening FTA scientists (e.g. around a gender-responsive research agenda on forest and tree-based value chains). Lessons learned from FTA's effective interdisciplinary, experiential learning process have been shared with other development and environmental organizations who seek to meaningfully integrate gender in their institutions and agendas (Elmhirst et al. 2020). 


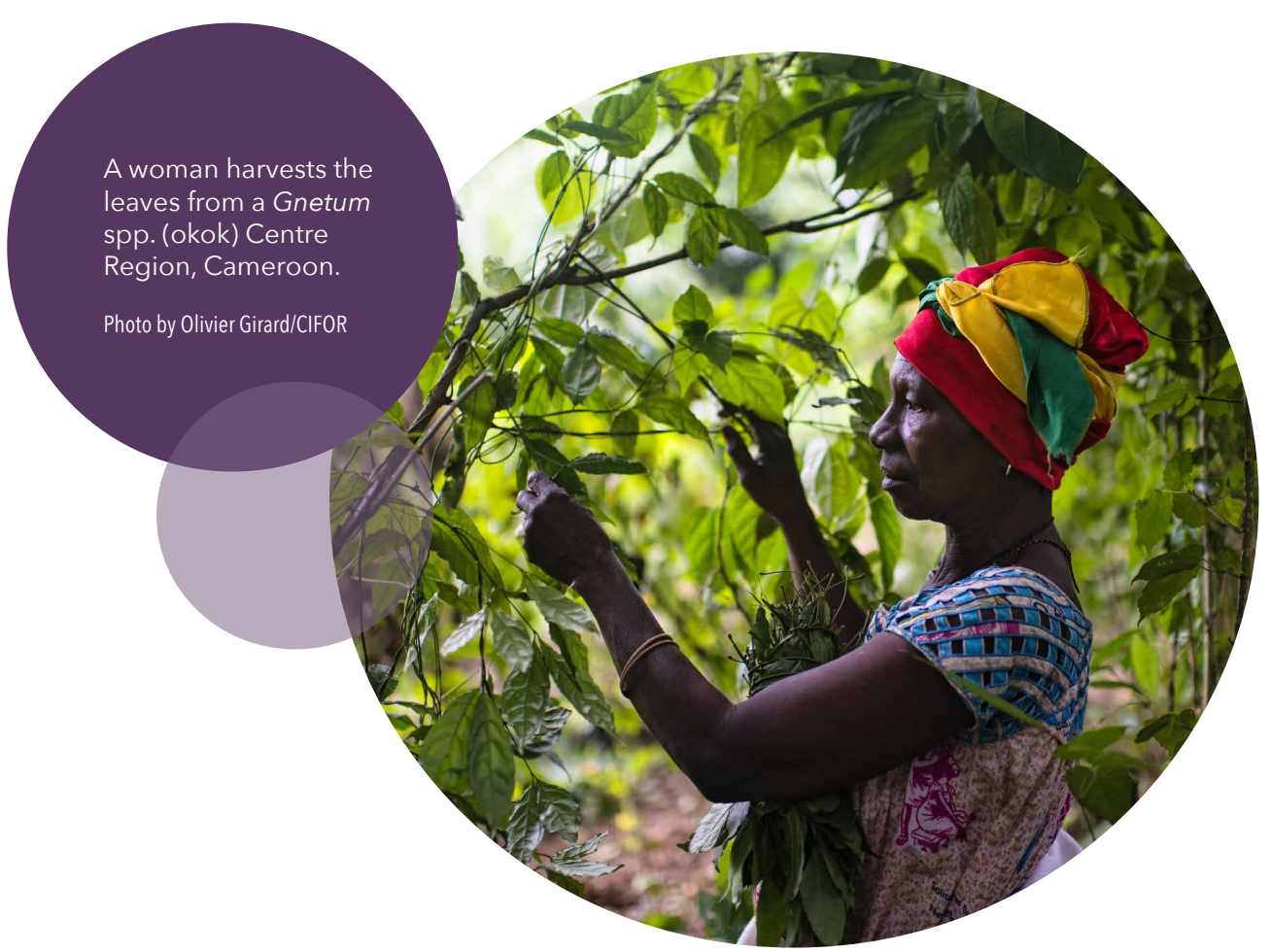

\subsection{Methodological and conceptual contributions}

In an important conceptual advance in forestry, agroforestry and natural resource management, FTA has challenged researchers, practitioners, and policymakers to move beyond the men-versus-women dichotomy and adopt an intersectionality approach in their analyses. Intersectionality refers to the ways in which multiple aspects of social differentiation, such as gender, age, ethnicity and caste, and socio-economic status, interact with each other to create social marginalization (Crenshaw 1989). As systems of oppression or discrimination intersect their effects are compounded. This means that engaging with women as a homogeneous category underestimates the marginalization of groups and individuals who are disadvantaged due to multiple aspects of social differentiation. Intersectionality generates a more complex and nuanced notion of gender, and calls for understanding the particularities that different social inequalities bring to resource management processes.

FTA works on forest product value chains (e.g. Elias and Arora-Jonsson 2017; Gallagher et al. 2020), climate change (Djoudi et al. 2016), community-based forest management (Chomba et al. 2015; Asher 2016; Duguma et al. 2018; 
Elias et al. 2020a), as well as reviews of global perspectives on gender equality in the sustainable development goals (Asher and Sijapati Basnett 2016; Arora-Jonsson et al. 2019), among others, demonstrate the need to adopt such a perspective in order to identify and reach and deliver outcomes to the most vulnerable people. These works have informed FTA's development of a manual (Colfer et al. 2018) and a chapter in a handbook (Colfer et al. in press) on intersectionality to support scientists and practitioners in pursuing a deeper and more meaningful analysis of how power inequalities in multiple social relations interact to create and perpetuate marginalization. FTA's work on intersectionality has reached large audiences within CGIAR and beyond, including through scientific conferences, webinars ${ }^{10}$ and capacity-building workshops. ${ }^{11}$

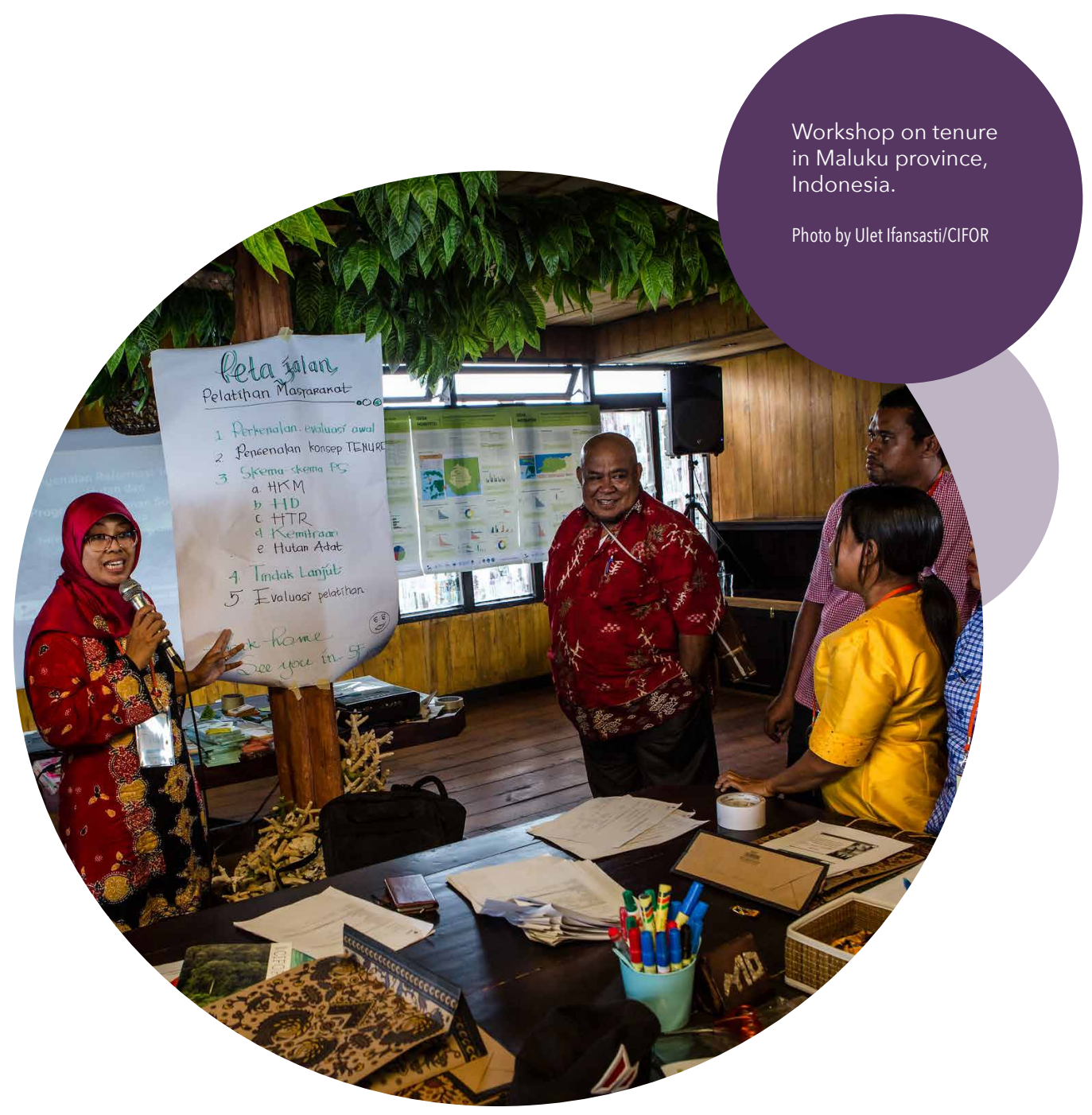

${ }^{10} \mathrm{https} / /$ /dev.ckm.ilri.org/cgiar-gender/webinar-2018-intersectionality/

${ }^{11}$ https://www.slideshare.net/CIFOR/intersectionality-80634434?qid=639372bb-031f-45ef-9404-e64ae9defb$\mathrm{cf} \& \mathrm{v}=\& \mathrm{~b}=\&$ from_search $=2$ 
An intersectionality approach has allowed the program to broaden the scope of its focus on inequalities beyond gender, to encompass other dimensions of social exclusion that are relevant to its research. For example, it provided an entry point for engaging with issues related to rural youth, as featured in FTA's revised agenda for research and action (CGIAR FTA 2020). FTA's approach to youth ${ }^{12}$ is rooted in an analysis of the social relations and structures that shape rural people's capacities to lead the lives they wish to in (and often beyond) tree-based landscapes. This perspective is described in a working paper (Clendenning 2019) and a brief (Clendenning et al. 2019) that provide a conceptual framework for FTA's research on youth, and in an FTA webinar on youth ${ }^{13}$ that discusses the challenges and prospects facing rural young women and men across regional contexts. FTA inroads with rural youth are reflected in influential studies, including a cross-country comparative analysis of rural young men's and women's aspirations (Elias et al. 2018c), which was cited in background papers for the International Fund for Agricultural Development's (IFAD's) 2019 Rural Development Report (White 2019) and in the report itself (IFAD 2019). FTA has conducted research on and with youth in various countries to shed light on the contextspecific ways in which age, generation and stage in the life cycle intersect with gender to shape agriculture and natural resource management (Li 2015; Elmhirst et al. 2017; Crossland et al. 2021a; Mausch et al. 2021). Dialogues with young women and men in Peru ${ }^{14}$ identified both barriers and ways to support youth to pursue careers cultivating high-quality varieties of cacao, in order to help address the critical issue of inter-generational succession in this value chain. In Mesoamerica, FTA research shed light on the potential risk for forest user associations whose members are aging, and the need for a succession plan as part of community planning processes (Stoian et al. 2018b). These works contributed to shifting the analysis from youth as an undifferentiated category of victims or saviours, towards the gendered and inter-generational relations and structures that influence the aspirations, capacities and constraints of rural young people in forests and agroforest landscapes.

Other FTA conceptual and methodological achievements include a growing focus on how gender norms underpin inequality and block women's capacities to innovate in forestry and agroforestry. FTA sat on the Executive Committee and led case studies in the global comparative study GENNOVATE, which paid attention to such norms at a time when they were still poorly explored in natural resource management. ${ }^{15}$ FTA work emphasized

\footnotetext{
${ }^{12} \mathrm{http}$ / / foreststreesagroforestry.org/research-portfolio/gender-equality-and-social-inclusion/

${ }^{13}$ https://www.foreststreesagroforestry.org/diverse-and-invisible-understanding-rural-young-people/

${ }^{14} \mathrm{https}$ // / alliancebioversityciat.org/stories/sharing-vision-youth-women-and-future-fine-flavor-cacao

${ }^{15}$ https://gennovate.org/
} 


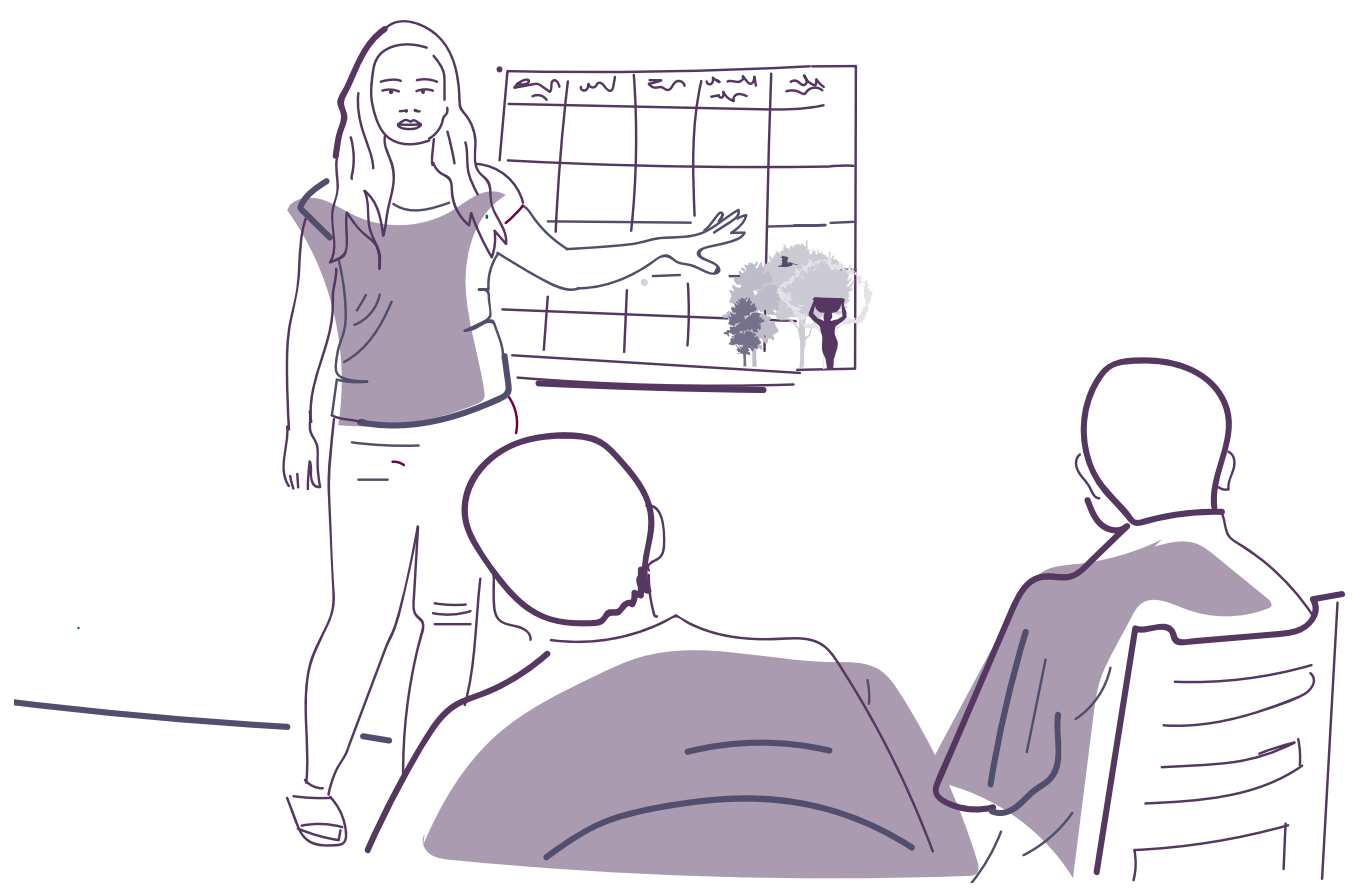

how gender norms shape the management of forests and trees, and how normative constraints contribute to some of the groups that depend on these resources staying in poverty (Elias et al. 2018b). Significant achievements in this area include a special issue ${ }^{16}$ co-led by FTA, on the study's findings, and contributions to several papers in the issue (Badstue et al. 2018a,b, 2020; Elias et al. 2018c; Petesch et al. 2018), as well as contributions to several tools for scientists, practitioners and decision-makers (Petesch et al. 2017; Elias et al. 2018a). GENNOVATE caused many ripples within GGIAR and beyond, including by influencing the direction of the joint programmatic work (FAO, IFAD and WFP 2020) of the Rome-based agencies - UN Food and Agriculture Organization (FAO), IFAD and World Food Programme (WFP) - on Gender Transformative Approaches (FAO et al. 2020).

Drawing on this empirical evidence that substantiates the relevance of gender norms to forestry and agroforestry, FTA has engaged in research to test approaches that can redress discriminatory norms and enable greater equality (aka Gender Transformative Approaches). In the context of a large restoration project in Ghana, a study ${ }^{17}$ showed that gender transformative approaches can support behavioural change towards a more equitable sharing of household chores, and that gender transformative approaches could be accepted by participants as an opportunity to improve household well-being.

\footnotetext{
${ }^{16}$ http://agrigender.net/all_issues.php

${ }^{17}$ https://www.worldagroforestry.org/blog/2018/12/21/challenging-gender-norms-around-trees-and-land-restoration-inwest-africa-can-research-be-transformative
} 
These approaches were also piloted as a means to address systemic issues that hinder gender equality in Fairtrade supply chains, to inform Fairtrade's Gender Strategy ${ }^{18}$ (Gallagher et al. 2020). Moreover, a current six-country FTA study is gathering evidence on how gender transformative approaches can enhance women's land rights ${ }^{19}$ across regional contexts and land-use systems. Early research findings and engagement in this field have shaped FTA's emphasis, in the CRP's Phase 2, on transformative approaches that challenge the power dynamics and structures that underlie gender inequality, rather than merely addressing its symptoms, such as unequal income and access to resources (CGIAR FTA 2020).

FTA's methodological work also includes a body of work on participatory research approaches for enhancing gender equality in natural resource management and forest and agroforestry landscapes. Several FTA studies developed, adapted and tested such approaches, and published guides, tools and peer-reviewed papers to demonstrate their usefulness in specific contexts (Elias and Morgan 2016; Mathez-Stiefel et al. 2016). For instance, work on adaptive collaborative management and a related field guide illustrate the value of this collective problem-solving and management approach, which facilitates gender-equitable negotiations and encourages broader participation by women in decision making (Evans et al. 2014, 2020). In one project, the creation of contact zones in India, where women and men from different age groups and castes come together to discuss forest management through participatory research, showed that such approaches can dismantle social divisions and promote unity in collective natural resource management (Hegde et al. 2017). Cross-country research in the context of the Gender Research Fellowship Programme facilitated the design and testing of participatory research approaches for studying social inclusion across multiple countries, and illustrated the strengths and challenges of various methodologies (Elias et al. 2017b; Faridah et al. 2017; Karambiri et al. 2017; Nchanji et al. 2017). FTA further showed the value of participatory approaches for working with government and development practitioners on gender-responsive tenure reforms, using 'participatory prospective scenarios' (Rodríguez Cortés and Ospina Rojas 2016; Bourgeois et al. 2017; Larson et al. 2019a; Monterroso et al. 2019; Jhaveri 2020), and for linking local, national and global needs, aspirations and capacities for forest restoration through participatory monitoring (Evans et al. 2018). These studies, among others, provided evidence of these actors' readiness to adopt and scale a set of participatory approaches in specific contexts; they also contributed significant concepts to FTA's work on governance and inclusive multistakeholder forums and platforms, discussed below.

\footnotetext{
${ }^{18} \mathrm{https}$ // /www.fairtrade.net/library/womens-access-equity-and-empowerment-study

${ }^{19}$ https://www.ifad.org/en/gender_transformative_approaches; https:// forestsnews.cifor.org/73913/new-global-initiativetransforming-gender-norms-in-land-and-resource-rights?fnl=en
} 


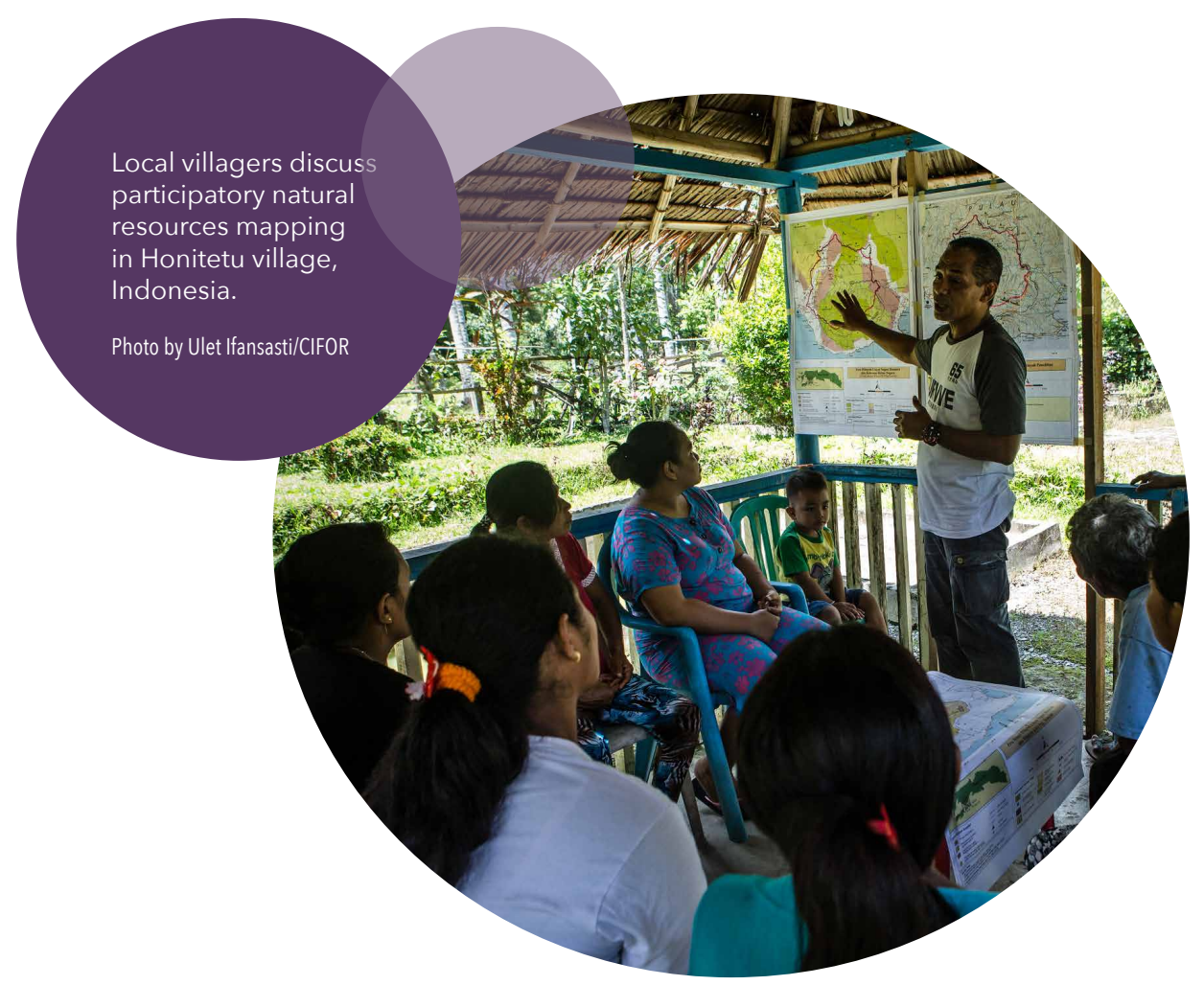

\subsection{Thematic contributions linked to FTA's operational priorities}

Gendered knowledge, roles and priorities in natural resource and biodiversity management

FTA conducted foundational gender research on gendered knowledge, roles, preferences and priorities of diverse social groups with respect to forestry and agroforestry, natural resources and biodiversity, including species and traits for conservation, domestication, utilization and management (Carney and Elias 2013; Dewi et al. 2013; Elias and Fernandez 2014; Kiptot et al. 2014; Degrande and Arinloye 2015; Elias 2015, 2016, 2017; Gutiérrez Velásquez 2016; Karambiri et al. 2017). This work increased the awareness of gendered differentiation, complementarity and inequalities in these areas and in relation to land use decisions, and substantiated the legitimacy of women's and men's voices in natural resource management matters (van Noordwijk et al. 2013; Villamor et al. 2013, 2014, 2017). Research in the Andean forest underscored the importance of incorporating local, gendered knowledge systems to achieve effective climate change adaptation (MathezStiefel 2016; Mathez-Stiefel et al. 2016). A special issue ${ }^{20}$ on gender and agroforestry looked at often ignored issues and dynamics that affect the adoption of sustainable agroforestry practices (Colfer et al. 2015c), including

${ }^{20}$ https://www.ingentaconnect.com/content/cfa/ifr/2015/00000017/a00404s4 
gender roles and the gender division of labour (Catacutan and Naz 2015; Gélinas et al. 2015; Kiptot 2015; Villamor et al. 2015), gendered land tenure and access to resources (Bose 2015), and gendered knowledge (Blare and Useche 2015; Bourne et al. 2015; Mbosso et al. 2015; Mulyoutami et al. 2015). FTA research linked gendered differences and inequalities in these areas to gender norms and dynamics at various scales (intra-household, community and beyond), and to gendered decision-making and adoption of innovations in natural resource management (Colfer et al. 2015b; Gumucio et al. 2017; Elias et al. 2018b). This body of work offers insights for identifying and addressing the constraints - asset- and resource-based, decisionmaking, normative, legislative, and other - and capacities of various groups of women and men in order to develop inclusive, equitable and effective agricultural extension and input delivery systems, agroforestry options, and resource management approaches.

\section{Resource tenure}

FTA also produced extensive knowledge on gender in relation to forest, land, and tree tenure and governance by documenting differences in the recognition of diverse rural people's rights under a range of tenure systems (e.g. private, collective, collective on public lands, etc.). Studies examined how social inequalities on the basis of gender and other forms of discrimination influence the capacities of Indigenous and forest-dependent women and men to benefit from the devolution of forest rights and responsibilities, and identified mechanisms for securing people's rights (Banana et al. 2012; Bose 2013; Coleman and Mwangi 2013; Narváez Guerrero 2014; Bose et al. 2017; Rosman Hernández 2017; Larson et al. 2018a). For instance, findings from a global comparative study on forest tenure reforms in Indonesia, Peru and Uganda demonstrated how age, socio-economic status and ethnicity influence marginalized groups' rights to resources, and the conditions under which reform processes have improved outcomes for women and other marginalized groups (Monterroso et al. 2019). A set of briefs (CIFOR et al. 2015) emphasized the need to address social differentiation in reforms that recognize collective rights in forestlands, and the relevance of disaggregating results to analyze how tenure formalization processes influence rights for vulnerable groups (Nsita et al. 2017; Cruz-Burga et al. 2018; Durán et al. 2018; Larson et al. 2018a; Monterroso et al. 2018; Monterroso and Larson 2018a,b). In Latin America, an FTA guest-edited Special Section of Women's Studies International Forum ${ }^{21}$ provided recommendations for policies to secure women's forest tenure rights in farms and communal forests (Bose 2017; Bose et al. 2017; Evans et al. 2017; Lastarria-Cornhiel et al. 2017; Mello and

\footnotetext{
${ }^{21}$ https://www.ingentaconnect.com/content/cfa/ifr/2015/00000017/a00404s4
} 


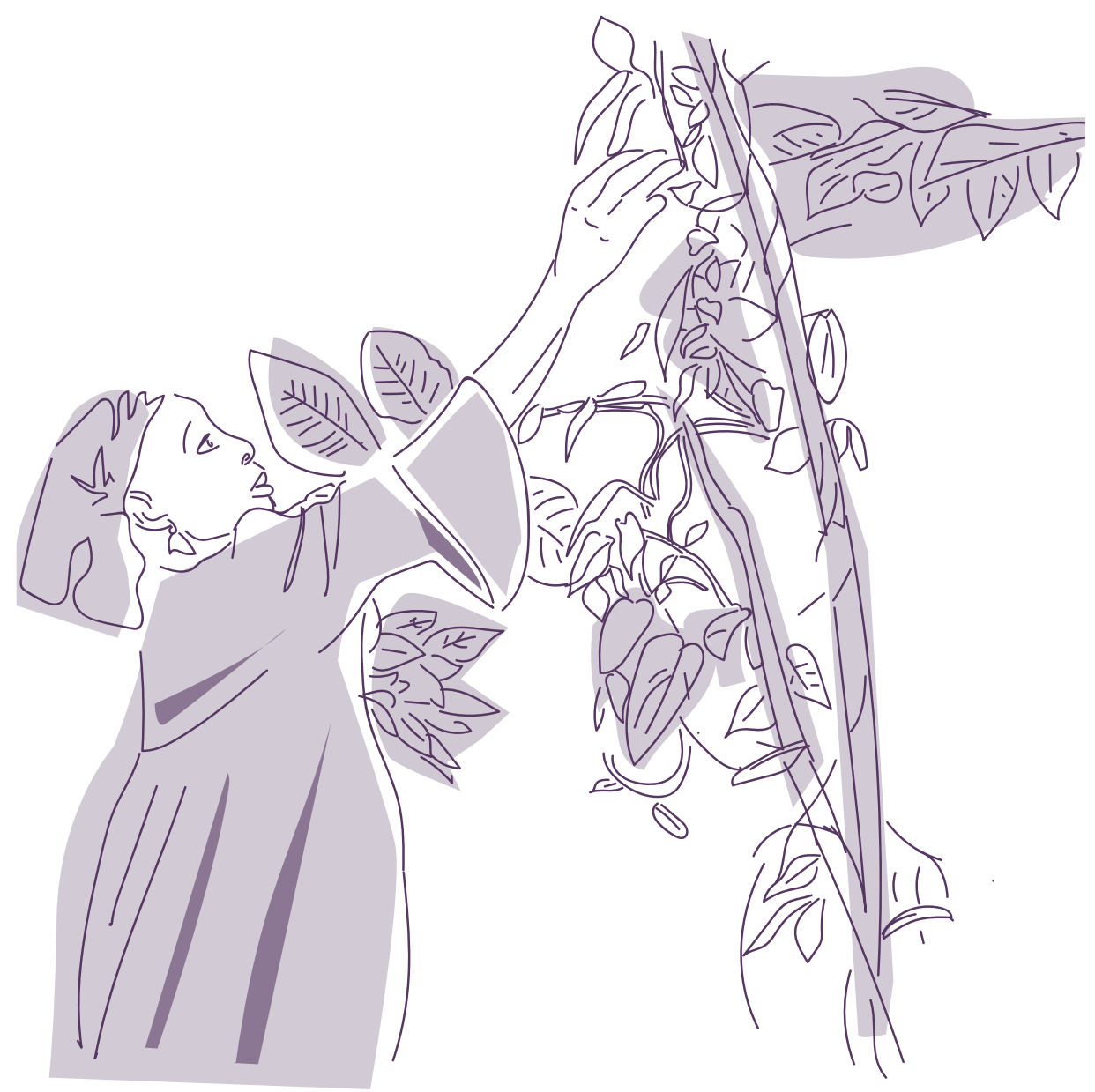

Schmink 2017; Radel et al. 2017; Vázquez-García and Ortega-Ortega 2017). This global research on tenure has culminated in a practitioners' sourcebook (Jhaveri 2020), which provides empirically-informed guidance on how to promote gender-responsive forest tenure reform in community-based forest regimes.

FTA has also contributed to revealing the distinctiveness of, and interrelations between, land tenure and tree tenure. For instance, a detailed mapping of rights (Pehou et al. 2020) to néré (P. biglobosa), a valued tree species in West Africa, as well as work on shea (V. paradoxa) (Elias and Arora-Jonsson 2017), showed that rights to these trees' products, and exclusions from these critical resources, are separate from rights to land, and are dynamic, and mediated by gender, lineage, marital status and residence status. These works offer policyrelevant evidence for enhancing gender equality and social inclusion amid rapid changes in land use, governance and markets. They are also highly relevant in the context of climate change interventions and restoration, which pose tenure risks to smallholders and in which insecure tenure rights often restrict women's engagement (Larson et al. 2018b). 


\section{Governance}

FTA has also addressed the institutional arrangements that promote meaningful participation by and the voice and influence of marginalized groups in governance processes, and the impact of these processes on sustainable resource management and benefit-sharing among smallholders at the forest margins. For instance, analysis across 10 countries in Africa and Latin America shows that women's participation, especially when women sit on forest councils or attain leadership positions, is highly correlated with less disruptive conflicts, and that women are more likely to participate in these decision-making processes where education levels are higher and there is less income inequality (Coleman and Mwangi 2013). FTA's research in this area spans and is often comparative across various countries, including Indonesia, Nepal, India, Cameroon, Nicaragua and Uganda, revealing the exclusions from forest governance that are based on gender and other sources of inequality (Sunderland et al. 2014; Chomba et al. 2015; Colfer et al. 2015a; Mukasa et al. 2013; Sijapati Basnett 2016; Elias et al. 2020a; Maukonen et al. 2020). In Nepal and other contexts, research has shown that high migration rates are reshaping forest access and governance through interlocking relations of gender, caste, class and ethnicity (Sijapati Basnett 2013; Hecht et al. 2015).

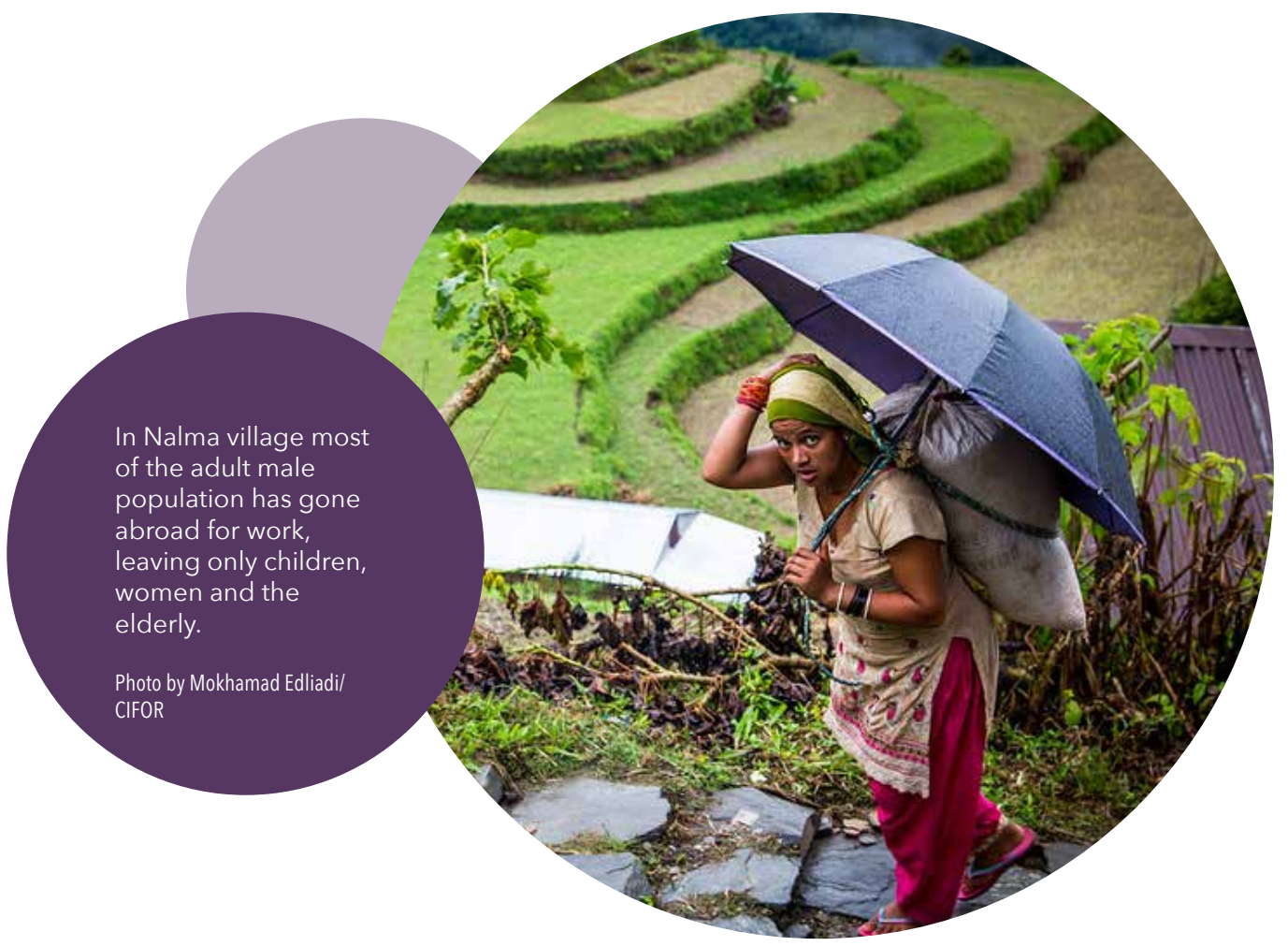

${ }^{21}$ https://www.foreststreesagroforestry.org/womens-studies-international-forum-special-section-on-latin-american-womensfarm-land-and-communal-forests/ 
FTA's work on participation in forest user group committees, co-management groups and forest commodity roundtable meetings includes the role of multistakeholder forums in improving equity and inclusion. Although these forums are often promoted as platforms for more inclusive and equitable decision-making, FTA research finds that the organizers of these forums spend little effort addressing the power inequalities among participants and the lack of participation by historically under-represented groups (Sarmiento Barletti et al. 2020a,b). This finding has resulted in the development of an innovative approach to support more equitable and effective forums that promote the inclusion of women and Indigenous Peoples in natural resource management and governance processes (Evans et al. 2021).

\section{Value chains and inclusive business models}

\section{Forest and tree-based value chains and inclusive business models,} particularly with regard to tree crop commodities and non-timber forest products, have received an increasing gender focus in FTA. Too often the issue of inclusive value chains ignores gender dimensions, focusing instead of issues of scale (i.e. smallholders versus big corporations). Over the past decade, FTA has generated empirical evidence on value chains where sexdisaggregated data on roles, participation, and benefit distribution was scarce, such as charcoal (Ihalainen et al. 2020) and fuelwood (Gautier et al. 2020); and on tree crops such as coffee and cocoa (Ambruster et al. 2017; Blare and Useche 2015; Gumucio et al. 2016b, 2017). In FTA's early years, the Poverty-Environment Network (PEN) cross-country study produced some of the most definitive evidence on gender differentiation, specialization, complementarities, and overlaps regarding non-timber forest product collection, processing and trade, revealing global trends as well as regional specificities (Sunderland et al. 2014). FTA investigated the gendered implications of cash-crop expansion and of various private-sector commitments to uphold social and environmental standards, such as zerodeforestation and product certification schemes. Research has also focused on the development, piloting and analysis of tools and methodologies that promote inclusive market systems and value chains. A global FTA review of gender in forest value chains (Haverhals et al. 2014; Ingram et al. 2016), and a subsequent review, focused on Latin America (Gumucio et al. 2018), analyzed the fragmentary evidence arising from case studies on the issue. They used a common framework that emphasized three aspects: i) the nature of gender differences in FTA value chains; ii) where these differences are concentrated; and iii) the factors underlying these differences. The reviews underscored the challenges that women face in access to more remunerative value chains and nodes, and the structural constraints that value chain development 
interventions must address to enable women to participate in, and to equitably benefit from forest and tree-based value chains. These findings provided the basis for guidance for developing more equitable interventions.

Other FTA studies continued to build evidence around the high but uneven reliance of rural women and men from socio-economically disadvantaged groups on non-timber forest products for subsistence and income (Asfaw et al. 2013; Pouliot and Elias 2013; Ingram et al. 2014; Elias and AroraJonsson 2017; Rousseau et al. 2019; Sithole and Byakika 2020). Work on timber and charcoal showed that improved production practices and more equitable distribution of benefits along value chains can help reduce pressure on forest resources (Njenga et al. 2013; Ihalainen et al. 2020), illustrating the links between equity in value chains and other forest outcomes. Women's fundamental roles in the sustainability of natural resource management were shown in a study ${ }^{22}$ on shea value chains in Burkina Faso. Women's interests in preserving shea trees as sources of nuts for shea butter production, enhanced by growing opportunities to participate in global shea value chains, were reflected in their efforts to safeguard shea trees in parklands. Competing aspirations for these parklands across gender and livelihood groups (e.g. beekeepers, charcoal producers, non-timber forest product traders) result in negotiations and trade-offs, which play out against a complex political and economic background.

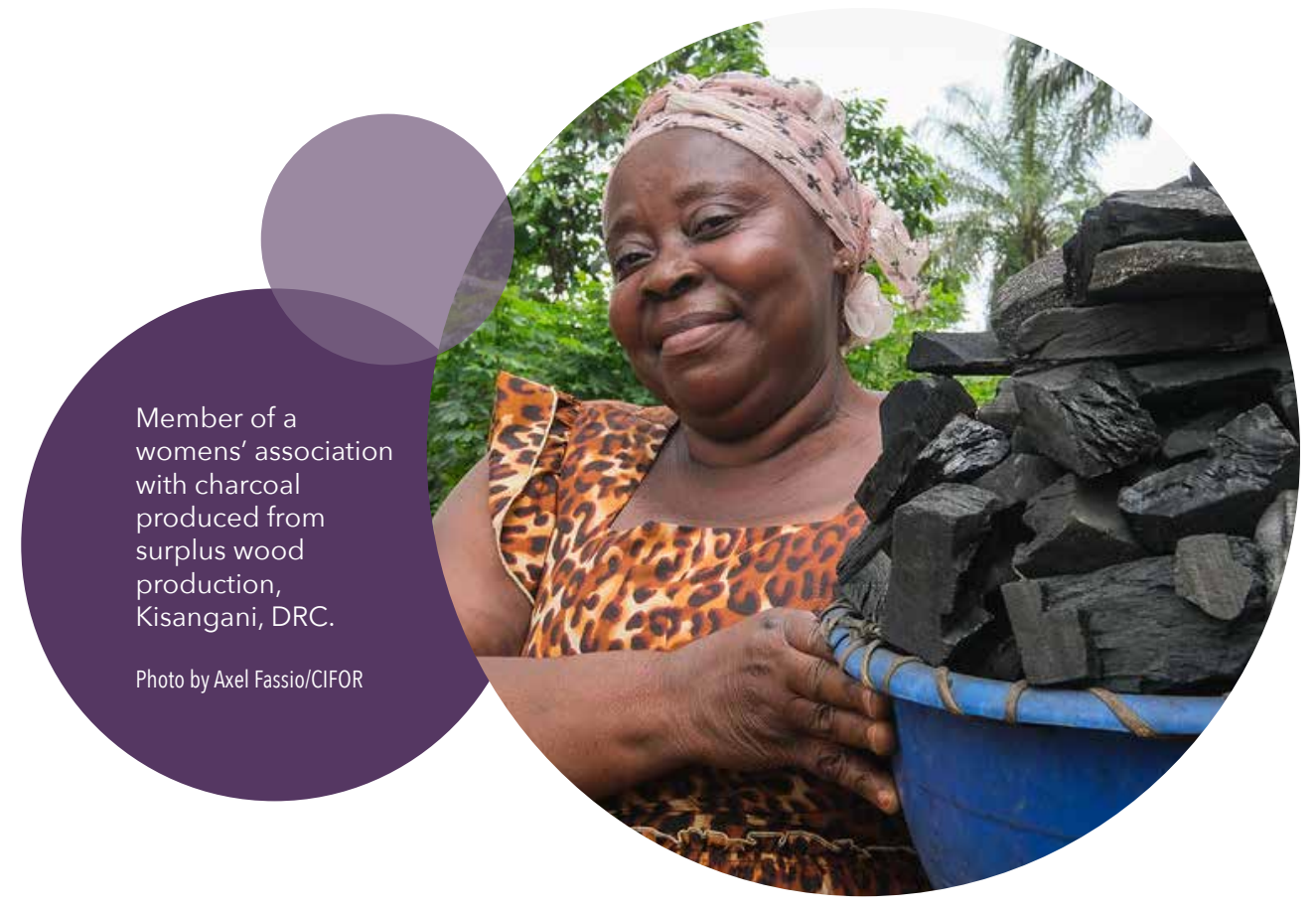

22 https:// forestsnews.cifor.org/73741/women-producers-in-burkina-faso-face-hardship-if-shea-industry-dwindles?fnl= 


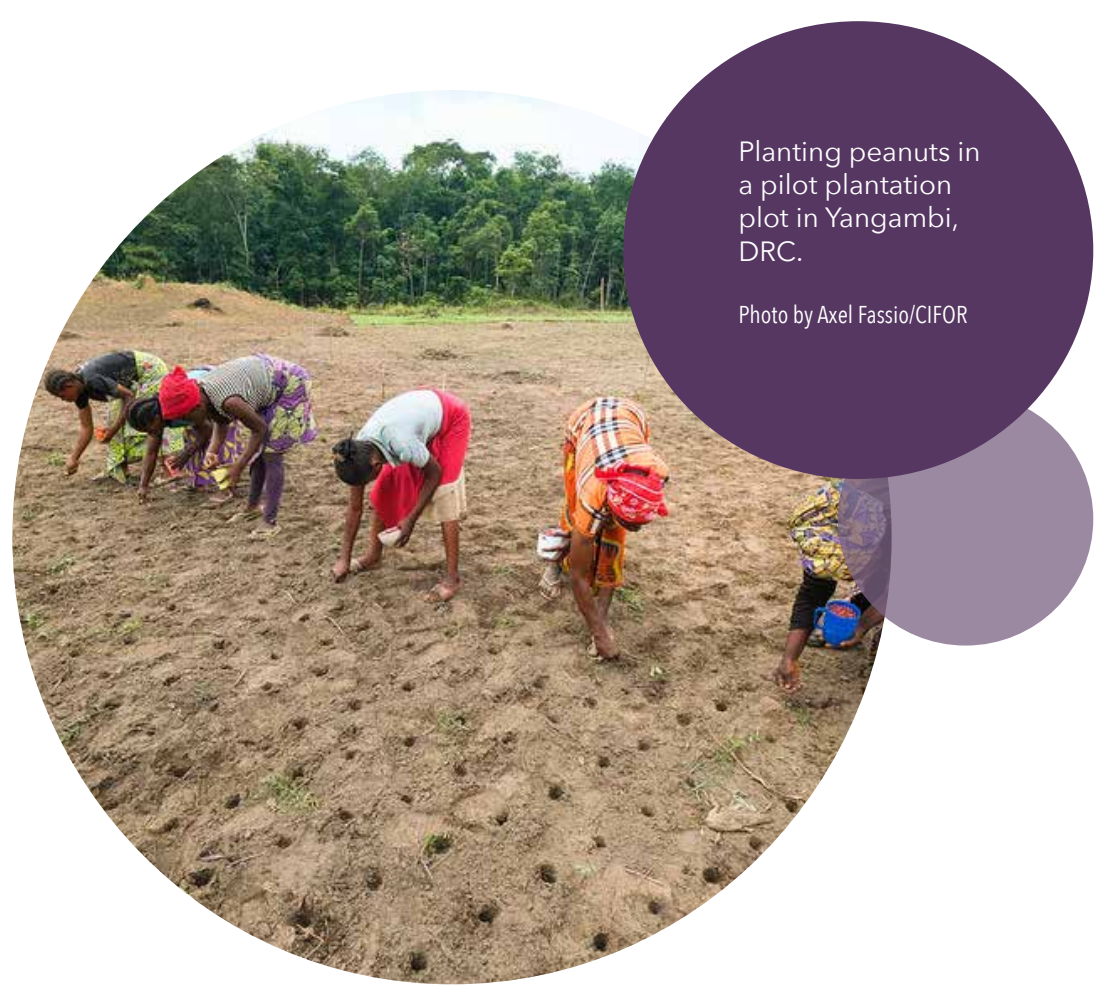

Understanding gendered roles and dependence on forest products, as well as the socio-cultural (norms and beliefs), technical (access to information, inputs, credit and markets), policy (public and private), and other barriers that prevent women and marginalized groups from participating in forest product value chains provided the basis for developing approaches to overcome these obstacles and enhance equality (Shackleton et al. 2012; Mulyoutami et al. 2013; Blare and Useche 2015; Gumucio et al. 2016a; Ingram et al. 2016; Blare and Donovan 2017; Armbruster et al. 2019; Ramos et al. 2019). A review of guides for gender-equitable value chain development (Stoian et al. 2018a) offered suggestions to practitioners who seek gender equality and poverty reduction outcomes through markets. Guidelines from FTA partner Bioversity offered field-tested strategies and good practices on how to achieve the multiple goals of gender equality and social inclusion, environmental integrity, and livelihood improvement through the sustainable management, use and trade of non-timber forest products (Jalonen et al. 2018). Research also informed the design of technologies to process non-timber forest products that respond to the specific needs of women and enable them to earn more income and reduce drudgery. For example, in Cameroon, FTA research supported the development of a method and a machine to drastically reduce the labourious, time-intensive processing of njansang fruit into a paste, a job traditionally carried out by women and children (Mbosso et al. 2015). 
Research focused on agribusiness expansion, particularly in oil palm landscapes (Li 2015; Sijapati Basnett et al. 2016), underscored the necessity for value chain studies and interventions to consider not only the extent of participation, but also the quality of that participation and the broader risks and trade-offs that landscape changes entail (Elmhirst et al. 2017). Further FTA work on inclusive business models shed light on marginalization in value chains for palm oil and other forest and agroforest commodities, showing the limits of market-driven mechanisms in overcoming gender inequalities (Sijapati Basnett et al. 2016; Gallagher 2016; Gallagher et al. 2020). These studies proposed mechanisms for tackling the intersectional drivers of marginalization, exclusion from, and adverse inclusion ${ }^{23}$ of women in plantations and tree crop commodity sectors.

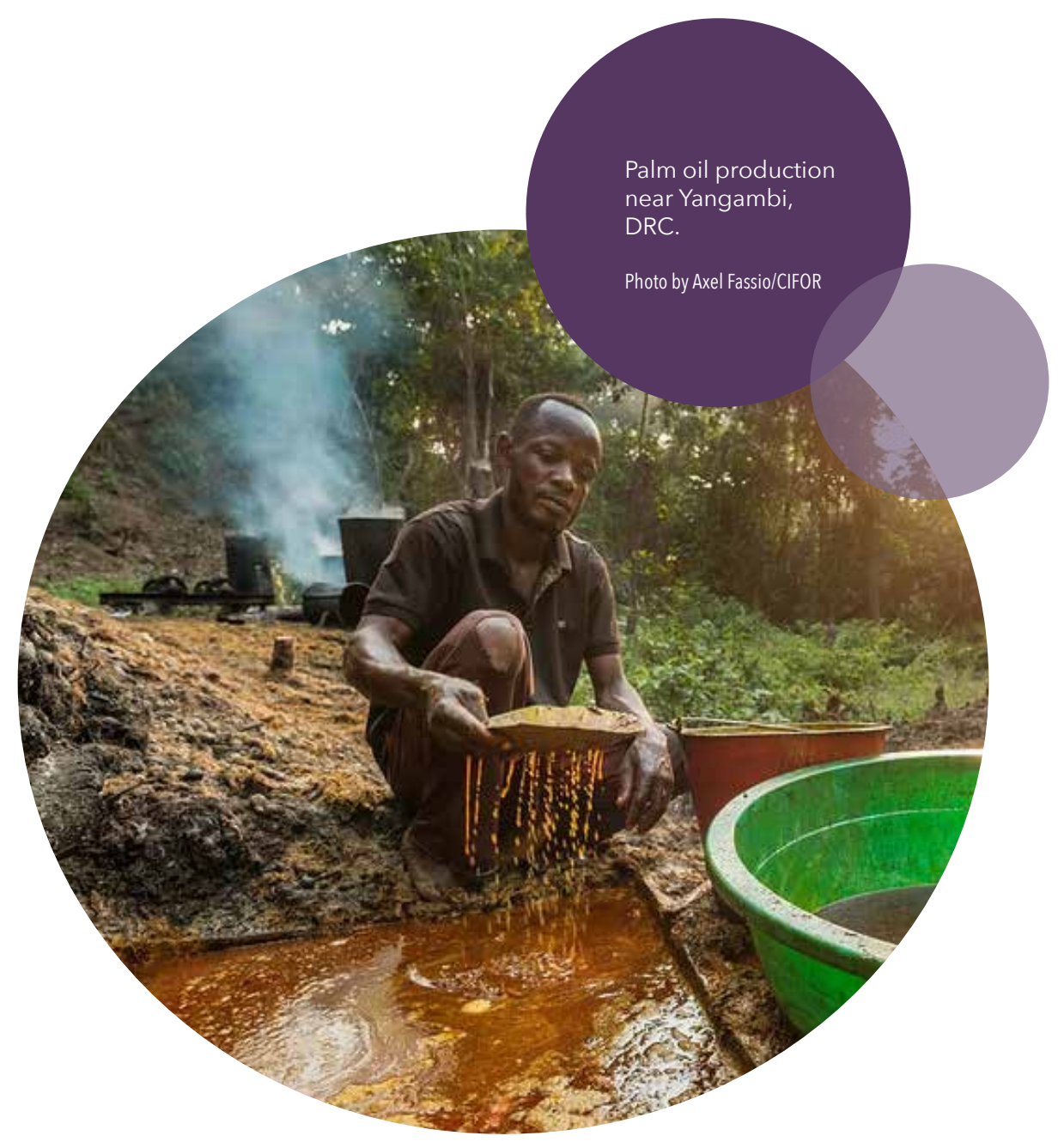

${ }^{23}$ Adverse inclusion occurs when people are able to participate in markets or services but under unfavourable terms or conditions. 


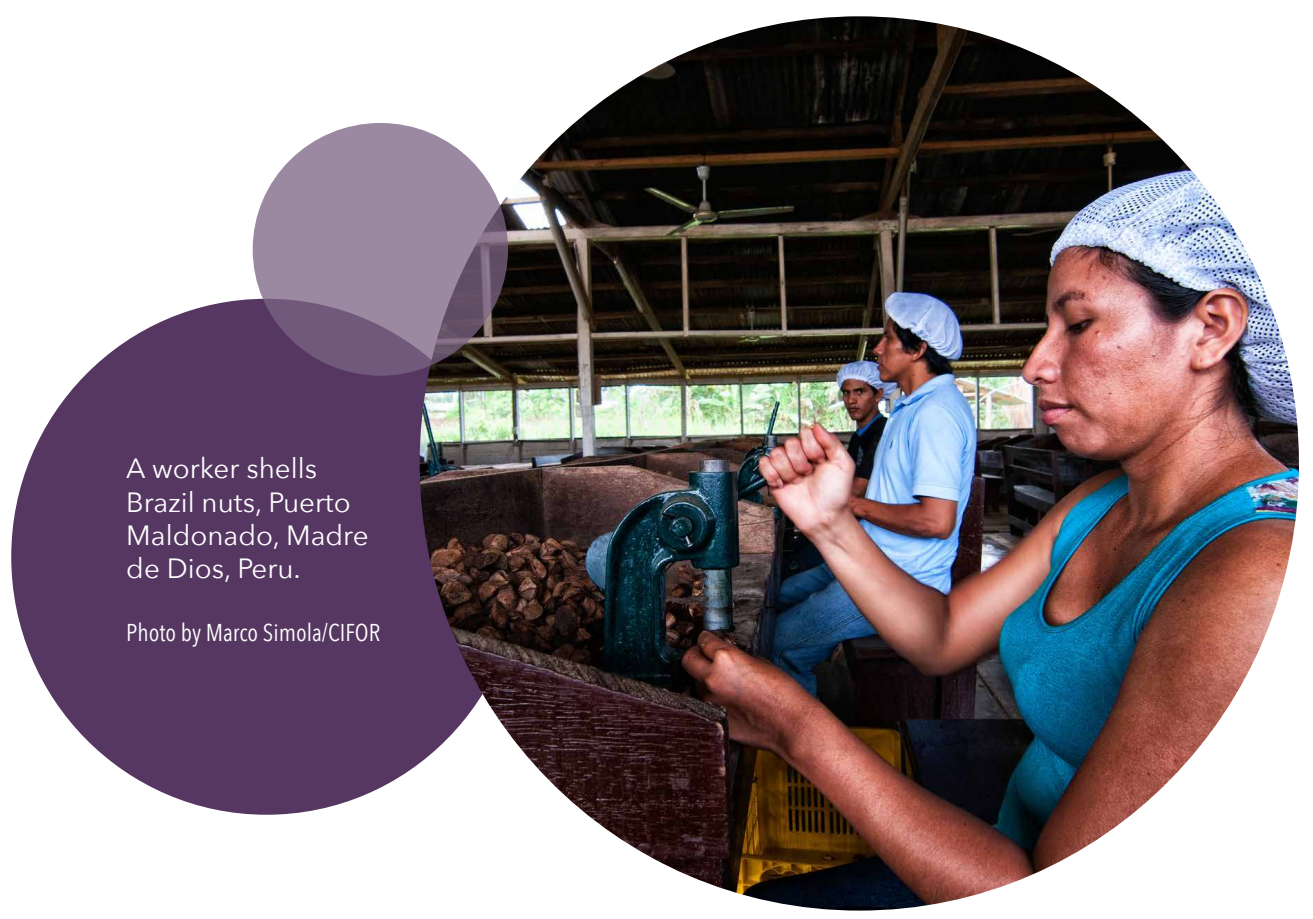

Climate action

FTA research has also advanced the understanding of and approaches to challenge the structural causes of gender-differentiated impacts of climate change; see also FTA Highlight \#12 in this series (Meybeck et al. in press). It has considered how climate change impacts - as well as strategies, policies and interventions to mitigate climate change and adapt to those impacts - constitute challenges or opportunities to reduce gender gaps in access to productive resources, redistribute labour, and make decision-making power more equitable. This research has focused on how gender and intersecting social variables, such as class and ethnicity, shape vulnerabilities and capacities to adapt to climate change (Djoudi and Brockhaus 2011; Brockhaus et al. 2013; Djoudi et al. 2013). Findings substantiate that gender and vulnerability assessments must go beyond static ideas of women's and men's respective capacities, needs and priorities (Djoudi et al. 2016). For example, as the effects of climate change become more tangible in China's Yunnan province, community responses to shocks such as droughts are challenging traditional gender roles and perceptions of these roles.

FTA research (Su et al. 2017) showed that although women were traditionally excluded from being village "water managers" (responsible for water tank and pipe maintenance and domestic water allocation at the village level) and considered incapable in this area, they became increasingly active in 
monitoring the allocation of water as water scarcity and related conflicts increased, and were positively recognized by their community for their capacity to solve conflicts and promote equal distribution of water through negotiation. These findings call attention to the possibilities that can open up for women to take on multiple and non-traditional roles amid climate-related changes. In Latin America, FTA's work on silvo-pastoral systems showed that mitigation actions can affect gender relations by imposing new labour demands on the household, and by altering access to technical information and monetary benefits (Gumucio et al. 2015). Assessing the potential impacts of planned climate actions on women's and men's adaptive capacities is thus needed to identify potential trade-offs between gender equality and climate goals, and to develop options to generate co-benefits. For example, FTA research showed the greater prospects that indigenous tree-based parklands (Vitellaria paradoxa and Parkia biglobosa trees) provide for women's adaptive capacities in West Africa, compared to monoculture tree plantations (Koffi et al. 2017; Djoudi et al. 2015 ${ }^{24}$ ), despite monoculture tree plantations stocking more carbon than parklands.

An important body of work focused on how to better align mitigation and adaptation policy and action with global mandates to advance gender equality. A comparative, long-term study on Reducing Emissions from Deforestation and Forest Degradation (REDD+); see FTA Highlight 11 (Martius and Duchelle in press), conducted in six countries, showed that unrealized expectations for REDD+, combined with little attention to gender in REDD+ initiatives, led to an important drop in the subjective well-being of women living in REDD+ villages (Larson et al. 2015, 2018b). Research in Vietnam showed that because benefit-sharing schemes ignored women's preferences and women struggled to receive REDD+ benefits, their

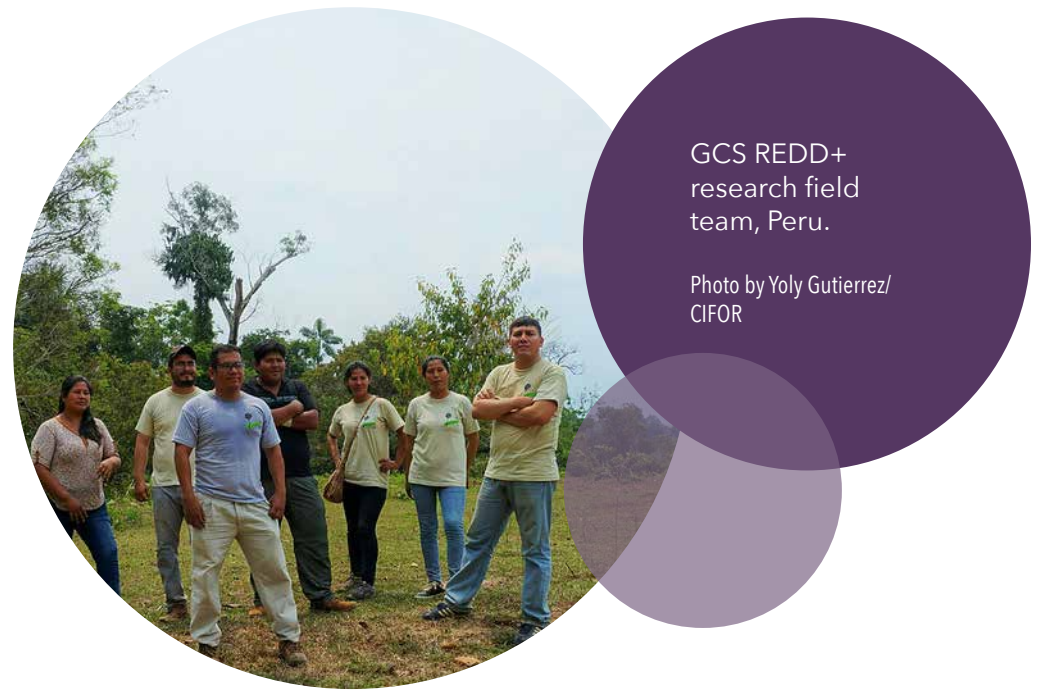

${ }^{24}$ https://fr.slideshare.net/CIFOR/linking-adaptation-and-mitigation-to-achieve-climate-compatible-development-in-drylands 
willingness to participate in REDD+ initiatives diminished over time (Pham and Brockhaus 2015; Pham et al. 2016). FTA work further illustrated the significance of women's participation in achieving the goals of REDD+; the opportunities for and limitations to gender-equitable participation in REDD+ (Bee and Sijapati Basnett 2017); and assessed various mechanisms, such as performance-based budgeting, ${ }^{25}$ by which climate finance can advance gender equality and poverty reduction (Atmadja et al. 2020a,b; Liswanti et al. 2020; IIX 2021).

\section{Ecosystem restoration}

Linking with these many areas of research, and with a proliferation of initiatives focused on ecosystem restoration around the world, FTA has contributed to developing the evidence base for and raising awareness of gender issues in land and ecosystem restoration, with an emphasis on Forest Landscape Restoration (FLR); see Volume 4 of this FTA Highlights series (Guariguata et al. 2021). In response to the high demand for policy and implementation guidance in this area, FTA produced a framework for integrating gender considerations in FLR (Sijapati Basnett et al. 2017), and is completing an online learning module on gender-responsive restoration that targets researchers, practitioners and decision-makers. FTA sees landscape restoration as people-centred, ecosystem-focused actions to improve degraded ecosystem functions, including productive functions, with attention to gendered implications. Yet, inclusion and equity are too often neglected by restoration projects and programmes. An FTA-led special issue on social inclusion in restoration brought together the empirical evidence and guidance for enhancing inclusion and equity through landscape restoration (Crossland et al. 2021a; Elias et al. 2021; Sigman and Elias 2021; Mansourian 2021; Sen et al. 2021; Singh et al. 2021). At the country level, research in Kenya generated empirically grounded lessons and recommendations for addressing gender in FLR (Ihalainen 2018), and for on-farm restoration options that reduce demands on women's time and increase their agency (Crossland and Paez Valencia 2020). A comparative study in Kenya and Burkina Faso links some types of men's outmigration with new opportunities for rural women through restoration by increasing their exposure to knowledge and their ability to negotiate access to farming resources, and by enhancing their recognition as farmers (Crossland et al. 2021b). In Burkina Faso, research showed the potential of land restoration to advance gender equality through group-based approaches that strengthen women's collective rights to land, access to resources, and technical and financial capacities to engage in restoration activities (Tiendrébéogo 2020).

${ }^{25}$ https:/ / www.youtube.com/watch?app=desktop\&v=urzSAF_xFQY 


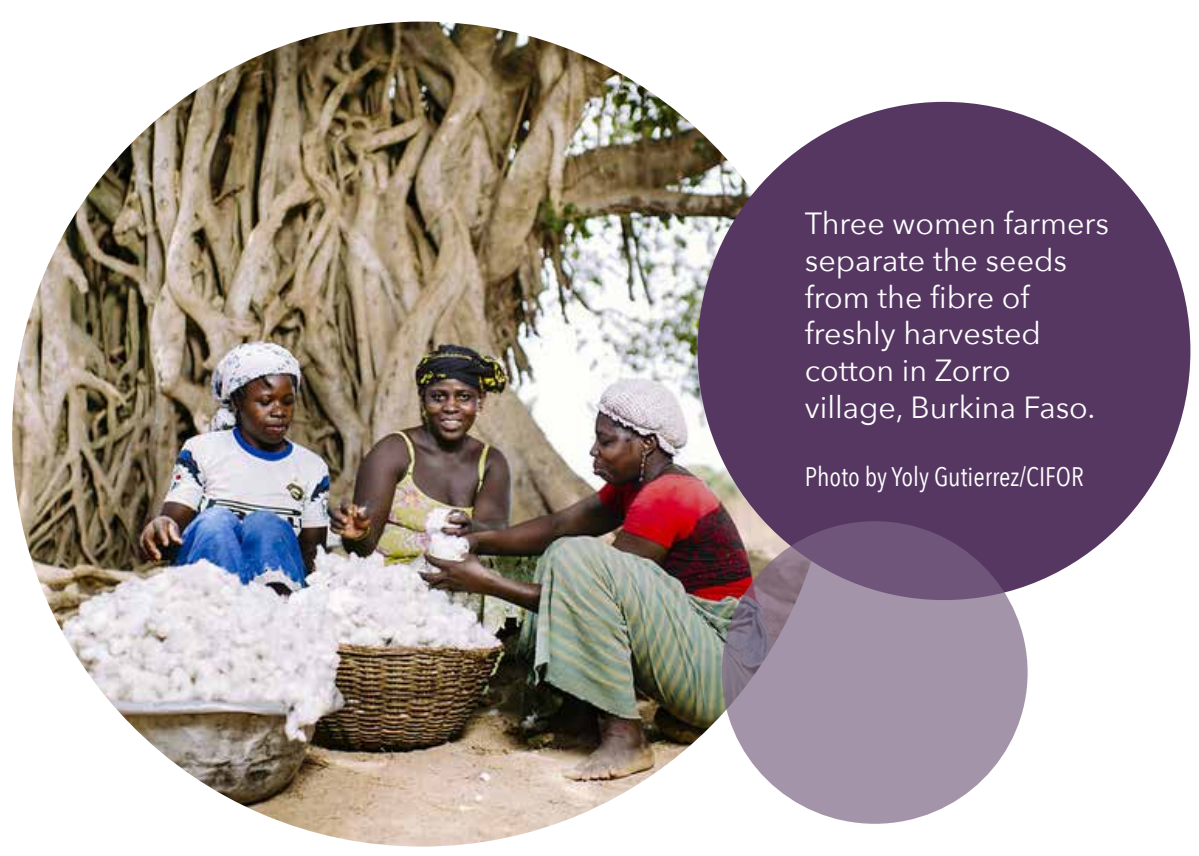

Synthesizing evidence and becoming a global clearinghouse on gender in forestry and natural resource management

FTA's efforts to advance gender research in forestry and agroforestry began with reviews of gender analysis in forestry research (Mai et al. 2011, 2012). Over the years, as the body of evidence, methodologies, frameworks, tools, and approaches grew, FTA sought to consolidate and synthesize evidence to become a global clearinghouse in this area. This entailed the production of several synthesis products, including special issues, papers, book chapters, and briefs (CIFOR et al. 2015; Colfer et al. 2015d; Asher and Shattuck 2017; Elias et al. 2017a; Asher and Varley 2018; Butali and Wekesa 2018; Conroy et al. 2018; Elias 2018; Kakungulu 2018; Kristjanson et al. 2018a; Mukasa and Tibazalika 2018; Nijbroek and Wangui 2018; Paez Valencia and Crossland 2018; Siles and Prebble 2018; Elias et al. 2020b). In 2016, an FTA-edited book (Colfer et al. 2016) on gender in forests provided the fundamentals for the range of actors working in the sector. Distributed to 500 developing country libraries and scholars, it was named Book of the month in April 2016 by Book Aid International. One year later, a prequel to this book, The Earthscan Reader on Gender and Forests (Colfer et al. 2017), was launched at the 125th anniversary congress of International Union of Forestry Research Organizations (IUFRO).${ }^{26}$ The reader was the first of its kind to bring together an accessible collection of theory, analysis, methodologies, and case studies from gender and forestry classics published over the last forty years, laying out key debates in the field.

${ }^{26}$ https:/ / forestsnews.cifor.org/51699/a-long-awaited-reader-on-gender-and-forestry? fnl=en 
Synthesis work was anchored in ongoing processes of global importance. For example, as the Sustainable Development Goals (SDGs) were identified, FTA produced several works linking gender, inequality and natural resource management and forest outcomes to this global agenda (Sijapati Basnett 2018; Arora-Jonsson et al. 2019; Sijapati Basnett et al. 2019). FTA further contributed to assessments of the implementation of global agendas, including IUFRO's Global Assessment on Forests and Poverty (Hajjar et al. 2020) and the Assessment of the New York Declaration of Forests' Goal 10, which addresses the persistence of gender bias in forest governance (Conway et al. 2018, NYDF 2018). Other contributions, both general (i.e. gender and forests/agroforests/natural resource management) and thematic (e.g. gender and value chains, climate change, restoration, etc.), helped position FTA as a knowledge broker on gender in natural resource management, as did FTA's gender webpage, ${ }^{27}$ which is a resource hub for policymakers, practitioners, academics and students worldwide. This wide-ranging review work provided the basis for informing and influencing international policymaking on climate change, biodiversity, restoration and other issues. For instance, FTA research on climate change was synthesized to inform the equitable implementation of REDD+ schemes (Larson et al. 2014) and the revision of the Green Climate Fund's Gender Policy and Action Plan (Ihalainen et al. 2017). An FTA submission to the United Nations Framework Convention on Climate Change's (UNFCCG) Subsidiary Body for Implementation on gender and climate change synthesized FTA's work in this area and facilitated the inclusion of FTA scientists in UNFCCC processes. Submissions to the UN Convention on Biological Diversity $(\mathrm{CBD})$ in relation to the post-2020 Global Biodiversity

Framework and to its draft Outline for a Gender Plan of Action, as well as to the UN Decade on Ecosystem

Restoration on its Draft Strategy, played a similar role.

In addition to working in the rice fields in Nepal, women also have to find grass for fodder

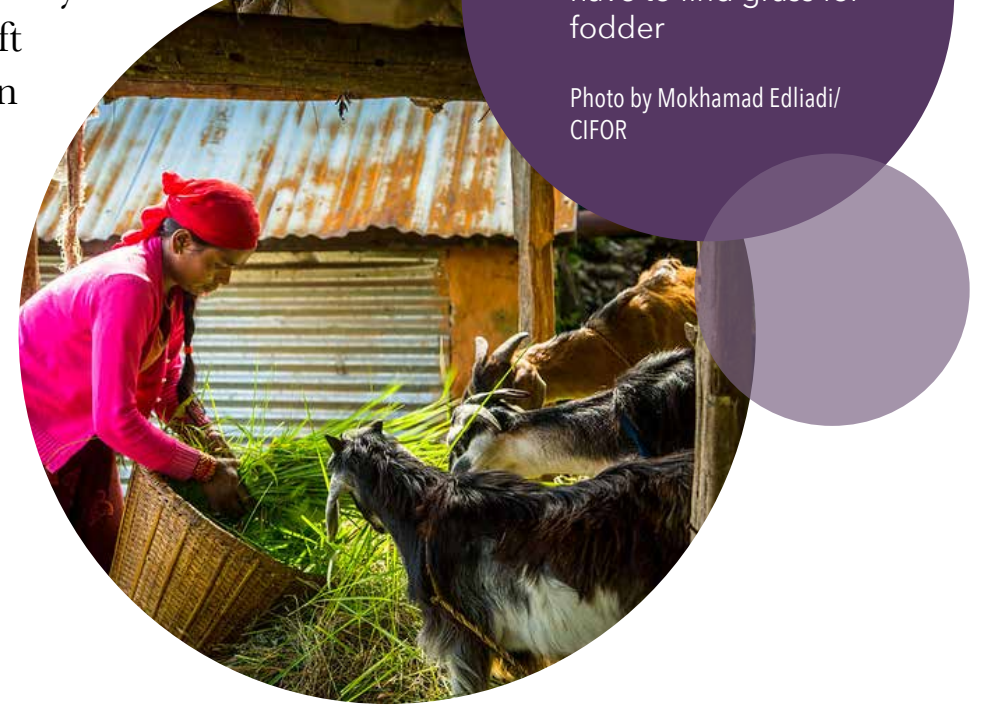

${ }^{27}$ https://www.foreststreesagroforestry.org/research/cross-cutting-themes/gender-equality-and-social-inclusion/ 


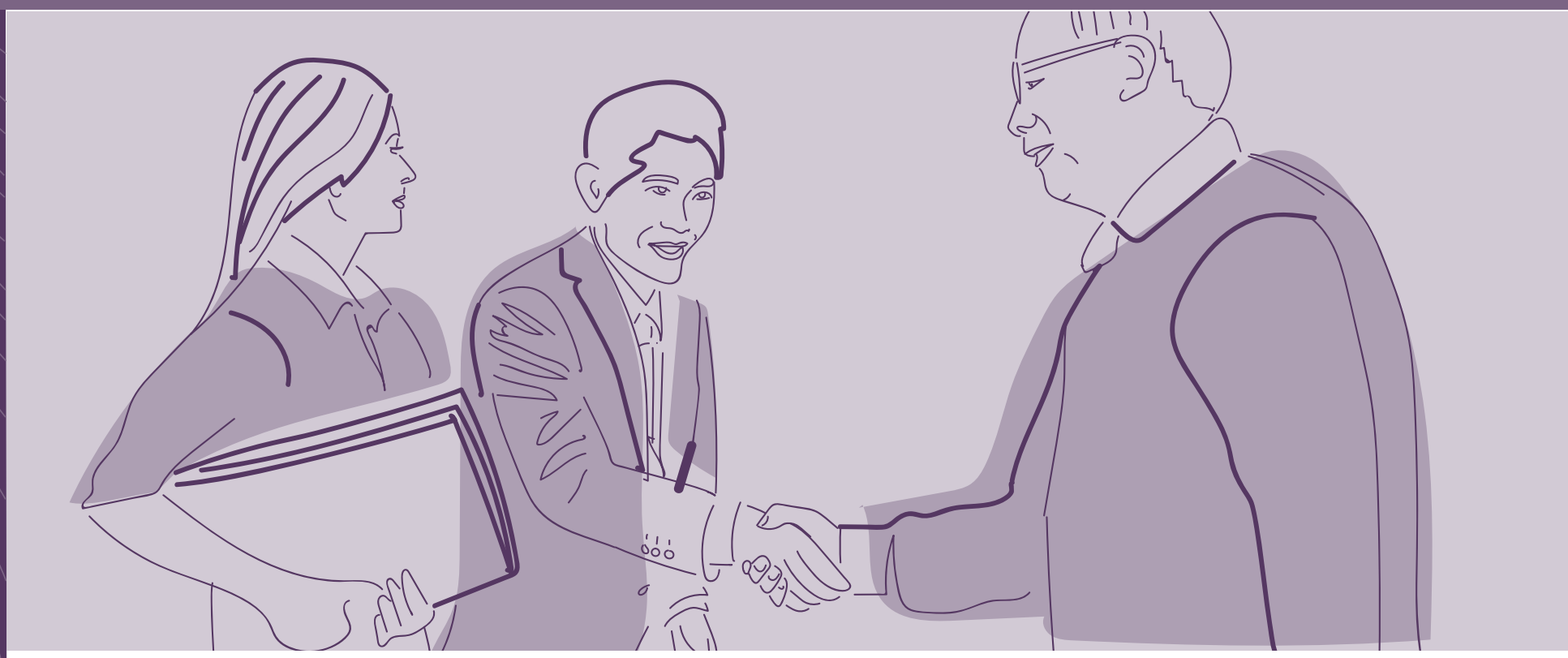

\section{Outreach and outcomes}

Engaging stakeholders, forging partnerships, and gaining a seat at the table

As noted earlier, stakeholder engagement is a key component of FTA's original Gender Strategy (CIFOR 2013d) and revised research agenda and action plan (CGIAR FTA 2020). The CGIAR-IEA (2017) Evaluation of Gender in CGIAR notes that FTA was among the GGIAR Research Programs that were most actively building strategic partnerships to enhance uptake of gender research. FTA made substantial efforts to bring its research to the attention of the intended users, informing dialogues and collaborations with policymakers and development practitioners in various countries, across diverse themes, to effect change in mindsets, discussions and behaviours related to gender in forestry and agroforestry research, policy and practice. These dialogues and collaborations allowed FTA to keep abreast of the needs of stakeholders, which is critical to the relevance and demand-driven nature of FTA research. As noted by the CGIAR-IEA $(2017,38)$ evaluation, "FTA's experience is that investment in developing their profile in gender research and building partnerships has yielded tangible returns in the uptake, demand and quality of gender research." Examples of these partnership building processes are provided here.

Collaborations in writing and producing joint outputs with influential partners, drawing on FTA gender research, strengthened partnerships and gave FTA the opportunity to influence high-level processes. For instance, 
UNFCGG (2018) recognized the usefulness of an FTA-led set of briefs on gender and climate action (Bioversity International et al. 2015) produced with 13 partner organizations, including UN bodies and international nongovernmental organizations, for the 21 st Conference of the Parties (COP 21 in 2015) in Paris. FTA partnered with UN Women to develop a research paper on gender issues under the CBD (UN Women 2018a) that was later submitted as a note by the Executive Secretary ${ }^{28}$ and considered at COP 14 in Egypt. FTA established and coordinated a Gender Constituency at the Global Landscapes Forum, which brought together 26 local, regional and international organizations and agencies to share knowledge of, and advocate for, inclusion in the field of gender and restoration. Under FTA's lead, the Constituency organized a set of briefs ${ }^{29}$ on gender and restoration (Kristjanson et al. 2018b) and a webinar on gender equality in restoration, ${ }^{30}$ among other events, keeping gender on the forum's agenda.

FTA used several communications outputs to reach intended stakeholders, including periodic Focus on Gender newsletters, ${ }^{31}$ blogs, photobooks (Bose and Savyasashi 2014; Tavenner 2018) and documentaries ${ }^{32}$

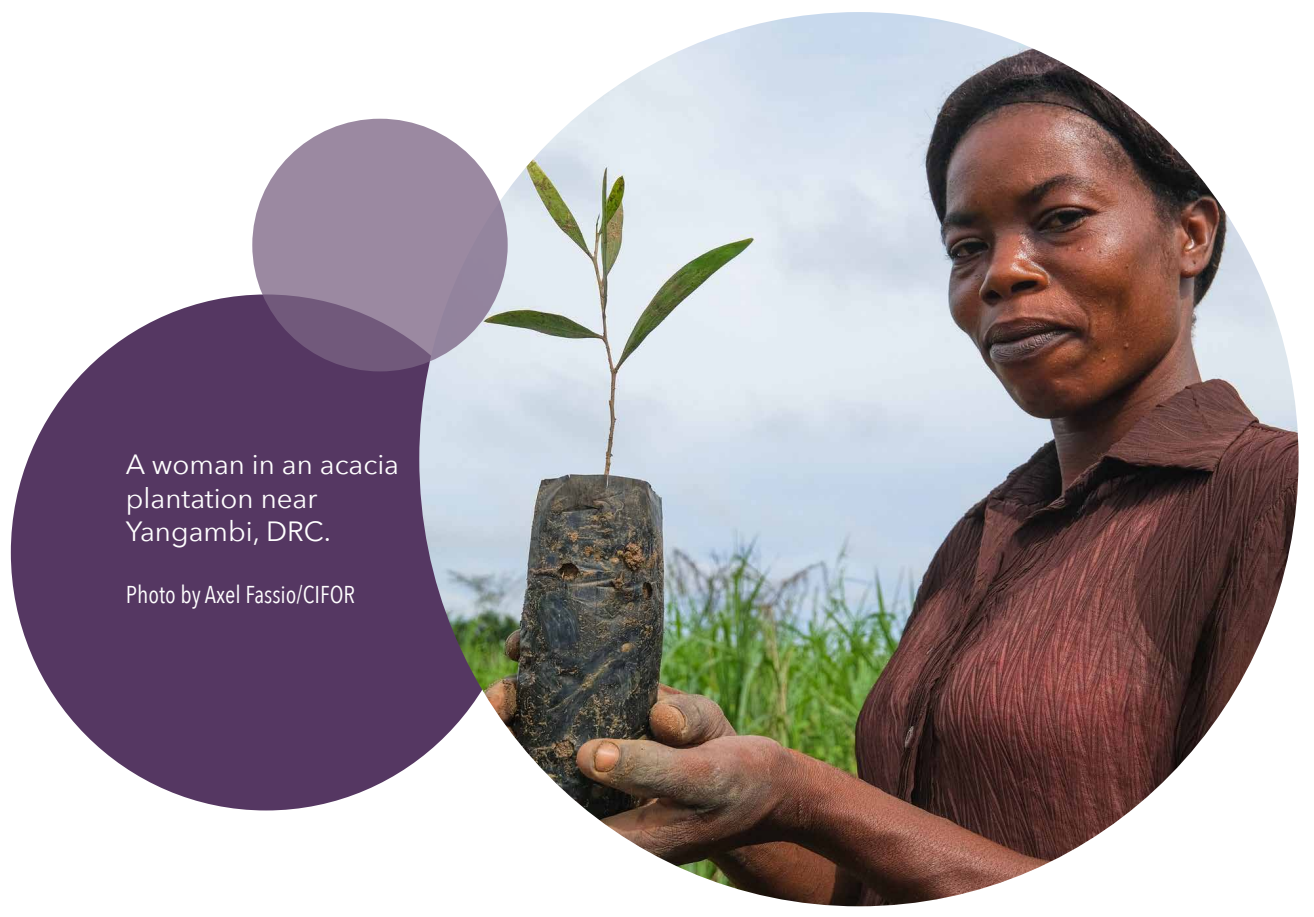

\footnotetext{
${ }^{28}$ https://www.cbd.int/doc/c/34b8/2445/f3c7ee9df40a841577c51638/cop-14-inf-21-en.pdf

${ }^{29}$ https://www.globallandscapesforum.org/publication/joint-infobrief-set-on-gender-equality-and-forest-landscape-restoration/

${ }^{30}$ https://events.globallandscapesforum.org/beyond-land-gender-equality-in-restoration/

${ }^{31}$ https://www.foreststreesagroforestry.org/fta-gender-newsletter/

${ }^{32}$ https://www.youtube.com/watch?v=zJ lz3r67LeE [In Vietnamese, with English subtitles].
} 
for diverse audiences. FTA also contributed to putting gender on the agenda at several high-level events, conferences, United Nations Committees and Conventions, and global convenings. They include the Committee on World Food Security, ${ }^{33}$ World Forestry Congress, ${ }^{34}$ Global Landscapes Forum, ${ }^{35}$ IUFRO World Congresses, World Congress on Agroforestry, ${ }^{36}$ World Bank Land and Poverty Conference, ${ }^{37}$ Society for Ecological Restoration World Conferences, ${ }^{38}$ FLARE Conference, ${ }^{39}$ UNFCCG COP 23, ${ }^{40}$ and accompanying Global Landscapes Forums.

Gender research findings were also presented in more targeted contexts to influence partners around the globe, including ministries, research organizations, private sector actors and the media, through book ${ }^{41}$ launches, film screenings ${ }^{42}$ webinars ${ }^{43}$ and knowledge sharing events, ${ }^{44}$ which got attention in national news ${ }^{45}$ and influenced national policy dialogues. FTA's research, outreach, and partnerships gave FTA gender scientists a seat at the table in several relevant national and international processes. Through capacity- strengthening events, expert panels, roundtables and participation in scientific committees, FTA has been able to share findings, tools, and innovations. ${ }^{46}$ For example, FTA was invited to bring a gender perspective and/or deliver gender training to the FAO Secretariat of the Thematic Working Group on Agriculture, Food Security and Land Use and the Koronivia Joint Work on Agriculture, ${ }^{47}$ International Fund for Agricultural Development (IFAD) staff on intersectionality and masculinities; MS Swaminathan Research Foundation's virtual consultation ${ }^{48}$ on "Science for Resilient Food, Nutrition and Livelihoods;" the Global Landscapes Forum on Biodiversity webinar ${ }^{49}$ on Indigenous rights; the UNFCCG constitutive body on Local Communities and Indigenous Peoples; the UNFGCG Least

\footnotetext{
${ }^{33}$ https://www.foreststreesagroforestry.org/news-article/feminism-forests-and-food-security/

${ }^{34}$ https://www.foreststreesagroforestry.org/news-article/yes-we-could-and-we-did-gender-specialists-share-success-stories /

${ }^{35}$ https://www2.cifor.org/cifor-at-glf-2017/enhancing-tenure-security-and-gender-equality-in-the-context-of-forest-landscape-restoration/

${ }^{36}$ https://www.worldagroforestry.org/wca2019

${ }^{37} \mathrm{https}$ // / www.cifor.org/corporate-news/follow-cifor-at-world-bank-conference-on-land-and-poverty/

${ }^{38} \mathrm{https}$ // /www.bioversityinternational.org/news/detail/why-gender-matters-in-forest-restoration/

${ }^{39}$ https://drive.google.com/file/d/1LP5JqRTam8ez0Xw9r_ie_spd7mBpQmaz/view

${ }^{40}$ https://forestsnews.cifor.org/52685/cop23-special-recognizing-gender-bias-restoring-forests?fnl=en

${ }^{41}$ https://www.worldagroforestry.org/blog/2017/08/18/why-china-should-include-a-gender-perspective-in-its-climate-

change-policies

${ }^{42}$ https:/ / forestsnews.cifor.org/52982/films-spur-dialogue-on-inclusive-agriculture-in-tanzania?fnl=en

${ }^{43}$ https://www.foreststreesagroforestry.org/news-article/webinar-genero-agroforesteria-y-cambio-climatico-en-america-latina/ [In Spanish; English version also available]

${ }^{44}$ https://www.cifor.org/event/forest-tenure-reform-implementation-in-uganda-what-lessons-for-policy-and-practice/

${ }^{45}$ https://kathmandupost.com/miscellaneous/2017/10/28/what-migration-means-on-the-home-front

${ }^{46}$ FTA scientists also sit on journal editorial boards and scientific committees, including IUFRO Division 6.08.01: Gender Research in Forestry.

${ }^{47}$ https://fao.adobeconnect.com/_a1026619000/pv6uyg7jhy4r/?proto=true [sound recording]

${ }^{48}$ https://www.youtube.com/watch?app=desktop\&v=O3FpeYKT374

${ }^{49} \mathrm{https}$ / / www.youtube.com/watch?app=desktop\&v $=$ DqYbx31 AVxI
} 
Developed Countries Expert Group (LEG); the Drylands Development Programme, ${ }^{50}$ the Regreening Africa Project ${ }^{51}$ and the Resilient Food Systems programme funded by the Global Environment Facility (GEF), ${ }^{52}$ among many other initiatives.

In addition, CIFOR-FTA was invited to sit on the gender subgroup of the Roundtable on Sustainable Palm Oil (RSPO) human rights working group (Sijapati Basnett et al. 2016). Following a joint FTA side-event on gender and climate finance at the UNFCCG COP 25, FTA and UNDP were asked by the member states of the Governors' Climate and Forests Task Force ${ }^{53}$ to design and deliver online workshops ${ }^{54}$ on mainstreaming gender in lowemissions development. These workshops, based on FTA research, offered evidence-based recommendations to support gender integration into the Governors' Climate and Forests Task Force's forests and climate agenda. Most recently, results from work on gender and climate finance were launched as part of UNDP's SDG Talks,${ }^{55}$ and key findings were shared at the Asia-Pacific Ministerial Conference on the Beijing+25 Review. FTA gender researchers contributed to task forces, such as FAO's "Best Practices - UN Decade on Ecosystem restoration" and "Socio Economic Sub Task Force on UN Decade on Ecosystem restoration," and to the GEF-8 expert group on gender, which seeks to advance synergies across the GEF's programmatic areas through consideration of gender. FTA scientists were also among the only representatives of research institutions invited to join the For All Coalition, ${ }^{56}$ which aims to inform gender integration under UN multilateral environmental agreements and conventions.

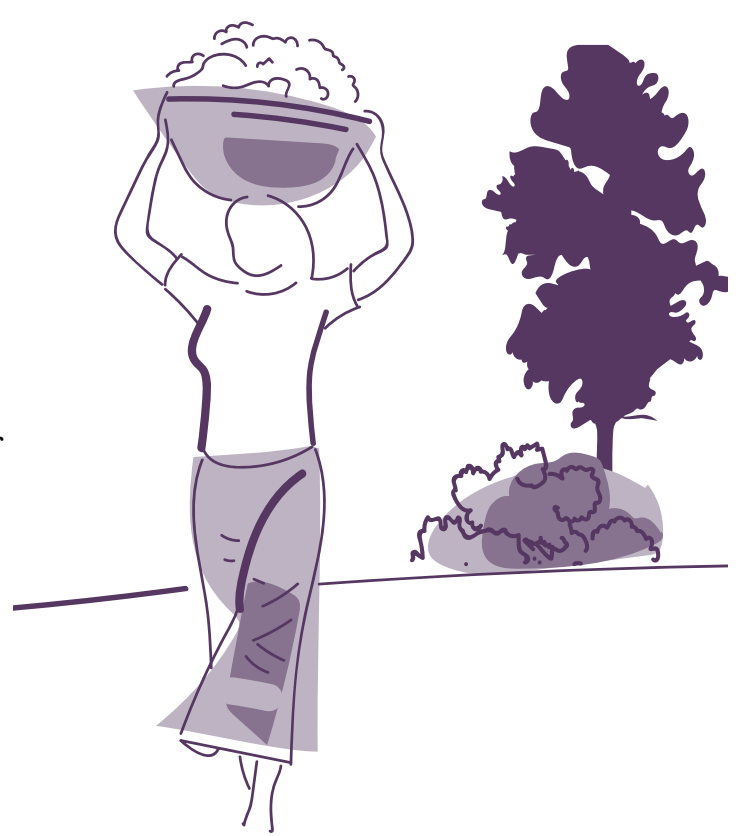

\footnotetext{
${ }^{50} \mathrm{https}$ // / www.worldagroforestry.org/project/drylands-development-programe-drydev

${ }^{51} \mathrm{https}$ // / www.worldagroforestry.org/project/reversing-land-degradation-africa-scaling-evergreen-agriculture-regreening-africa

52 https://resilientfoodsystems.co/

${ }^{53}$ The Governors' Climate and Forests Task Force (https://www.gcftf.org/who-we-are/) is a subnational collaboration of 38 states and provinces working to promote pathways to forest-maintaining rural development. It represents a significant platform for advancing forest and climate solutions at the jurisdictional level.

${ }^{54}$ https:// forestsnews.cifor.org/68417/mobilizing-to-address-gender-in-forests-and-climate-change-actions?fnl=en

${ }^{55} \mathrm{https}: / /$ www.youtube.com/watch?v=A5s8dE4r5ZU [In Indonesian]

${ }^{56}$ https://www.oas.org/en/cim/docs/ConceptNote-ForAllCoalition\%5bEN\%5d.pdf
} 


\section{Outcomes}

Comprehensively assessing the outcomes of such a wide-ranging gender mainstreaming program is challenging. The following highlights, along the two strands of FTA's gender strategy (see Figure 1), range from changes in discourse, programmes and policies to changes in behaviour and in gender equality at multiple scales (local, national, international) and across geographical contexts.

At the local level, building on earlier CIFOR achievements (Colfer 2005; Prabhu et al. 2009), FTA's gender work on forest use and management used participatory, qualitative and quantitative research methods, and gender transformative techniques such as Adaptive Collaborative Management. This created new opportunities for women to participate in forest management (McDougall et al. 2013; Evans et al. 2014). In Uganda, the approach provided a safe platform and allowed women's voices to be heard in the presence of men without intimidation or retribution (Mukasa et al. 2016a, b). This resulted in an 18-fold increase in the number of women in community forestry leadership positions and in a more gender-balanced forum where women's interests and priorities are taken into account. This, in turn, resulted in reforestation of degraded forests by local communities, women's involvement in the management of these forests, and women's increased capacity to receive benefits from forest reserves (Mukasa et al. 2016a). Intergender dialogues promoted through Adaptive Collaborative Management have resulted in some women in Uganda having their own plots and planting a greater diversity of tree species, including trees that women were formerly forbidden from planting, such as Eucalyptus spp., Pinus spp., and Maesopsis spp., for income (ibid.). Women's participation in decision-making, as well as their confidence, engagement and agency, increased, and they felt empowered to seek external assistance (Evans et al. 2014; CIFOR 2017). The Adaptive Collaborative Management approach further improved coordination among communities, state forestry agencies, and NGOs, and increased local people's access to resources.

At the national level, FTA findings and recommendations from research on REDD+ informed Vietnam's guidelines ${ }^{57}$ for gender mainstreaming in national PES policies, and have been incorporated in the UN-REDD planning in Vietnam and the UN-REDD (2011) guidelines on The Business Case for Mainstreaming Gender in REDD+. Country-specific findings from a multi-country comparative REDD+ study have also supported efforts to

\footnotetext{
${ }^{57}$ https://www.foreststreesagroforestry.org/news-article/update-on-gender-research-projects/\#cifor
} 
mainstream gender in REDD+ and the forestry sector; e.g. in Indonesia ${ }^{58}$ (Arwida et al. 2017). In Indonesia, research on gender and REDD+ led to a close collaboration with the Ministry of Environment and Forestry and the Ministry of Women Empowerment and Child Protection to mainstream gender into REDD+ and has informed the Ministry of Environment and Forestry Directorate General of Climate Change's position in international negotiations. Oxfam has used the results of research on the social impacts of oil palm in West Kalimantan ( $\mathrm{Li} 2015)$ to inform its Gender Transformative and Responsible Agribusiness Investments in South East Asia programme, and as a basis to increase the gender-responsiveness of the Roundtable on Sustainable Oil Palm criteria, indicators and guidance. In Peru, FTA contributed to the development of the national Climate Change Gender Action Plan, ${ }^{59}$ led by the Ministry of Environment and the Ministry of Woman and Vulnerable People, and supported by IUCN. FTA research on the gendered effects of migration on forest governance in Nepal (Sijapati Basnett 2013) has been used by the country's multistakeholder forestry programme to deliberate on the implications of migration and multi-local livelihoods on women and men in forested landscapes.

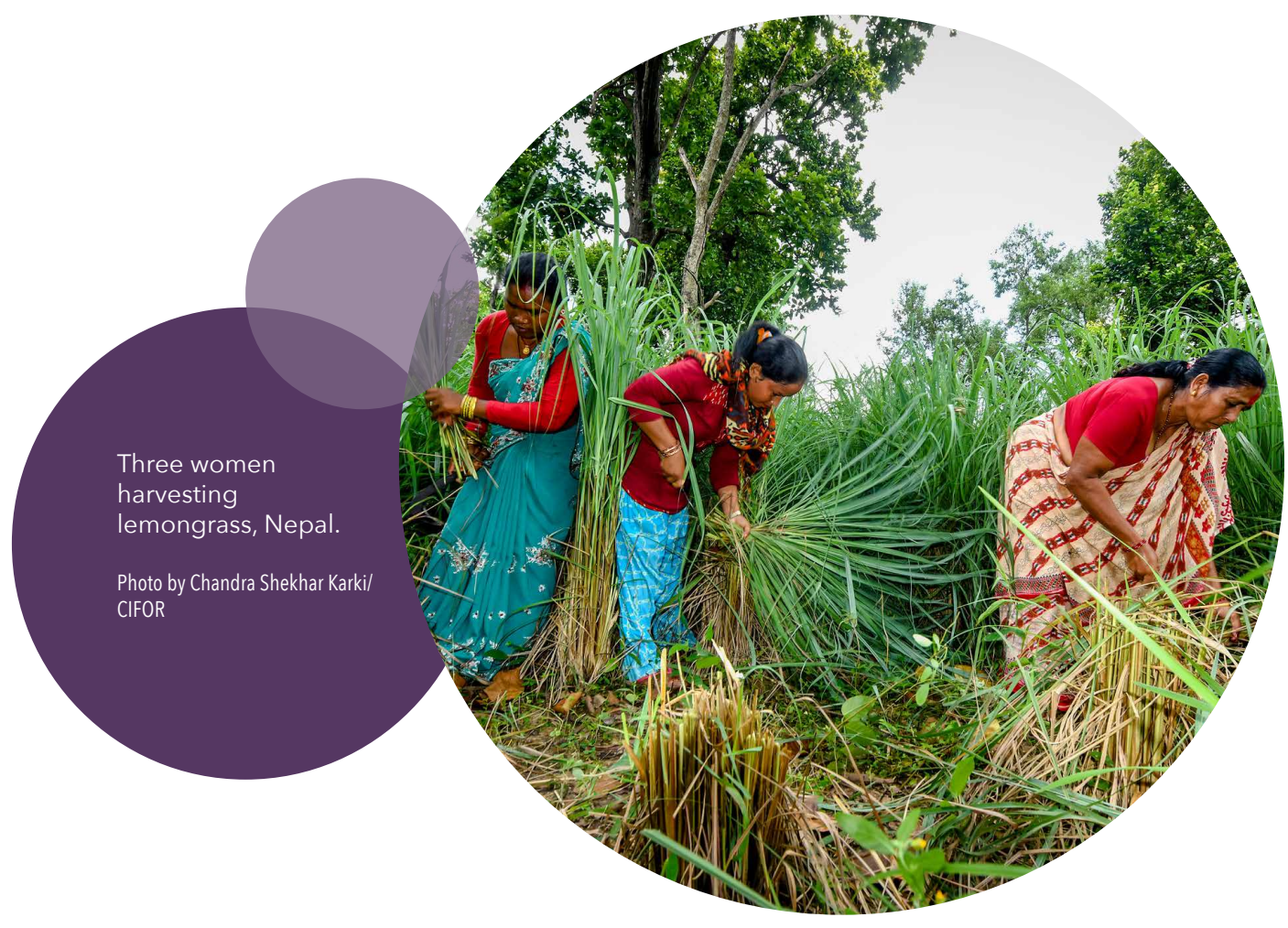

${ }^{58} \mathrm{Ibid}$.

${ }^{59} \mathrm{https}: / /$ www.climatelinks.org/blog/climate-change-gender-action-plan-developed-peru 
At the international level, FTA has contributed to mainstreaming gender in the Rio Conventions through a close collaboration with the United Nations Entity for Gender Equality and the Empowerment of Women (UN Women) and the Convention Secretariats. FTA has participated in and contributed to several meetings of experts led by the UNFCGC secretariat (CIFOR 2019) and the CBD secretariat (UN Women 2019c). This included a workshop ${ }^{60}$ to strengthen the gender-integration capacities of convention delegates, and others dedicated to influencing the Post-2020 Global Biodiversity Framework. ${ }^{61}$ FTA co-hosted a technical discussion, ${ }^{62}$ which resulted in key messages and recommendations for the First Meeting of the Open-ended Working Group (OEWG) for the framework being formulated (UN Women 2019a,b). Through this dynamic engagement with UN Women, the CBD secretariat and these expert groups, FTA has contributed to joint submissions with other organizations to inform the Post-2020 Global Biodiversity Framework, including during the Regional Consultation of the Group of Latin America and the Caribbean in Montevideo (UN 2019). FTA's work with the Rio Conventions has heightened the visibility of the GGIAR Research Program and demonstrated that gender is a legitimate field of concern in research and policy, and a relevant entry point for engaging with global policy processes.

FTA has contributed to other global initiatives to establish and track progress towards gender equality targets. For instance, FTA's recommendations on an indicator on "women's inclusion in national decision making on climate policies" for SDG 13 on climate change were retained in the global report Equal Measures 2030 (Equal Measures 2030 2018, 94). The report referenced FTA's submission to the UNFCGC Subsidiary Body for Implementation and two FTA studies (Coleman and Mwangi 2013; Pham and Brockhaus 2015), and underlined the importance of including women in national decision making on climate policies. FTA's submission was also widely cited in a recent synthesis report on gender and climate change developed by the UNFCGC secretariat (UNFCGC 2019). As a result of FTA engagement, a genderspecific indicator (1.1.e) is included in the Chatham House Forest Policy Assessment Framework. ${ }^{64}$ A number of FTA recommendations regarding the Green Climate Fund's Gender Policy and Action Plan (Ihalainen et al. 2017) are reflected in the fund's updated Gender Policy and Action Plan. FTA recommendations have also informed the gender strategy for the Roundtable

\footnotetext{
${ }^{60} \mathrm{https}$ // /www.cbd.int/kb/record/meeting/5818?Country=ca

${ }^{61}$ https://www.foreststreesagroforestry.org/news-article/reversing-dangerous-decline-of-nature-requires-global-initiativesto-engage-both-men-and-women/

${ }^{62}$ https://www.worldagroforestry.org/blog/2019/11/11/icraf-and-fta-host-first-technical-discussion-development-genderresponsive-post

${ }^{63}$ https://www4.unfccc.int/sites/SubmissionsStaging/Documents/201804032135---CIFOR_CGIAR\%20FTA\%20submission $\% 20$ to $\% 20$ SBI.pdf

${ }^{64}$ https://forestgovernance.chathamhouse.org/media/policy_assessment_framework_processing_consuming_countries.pdf
} 


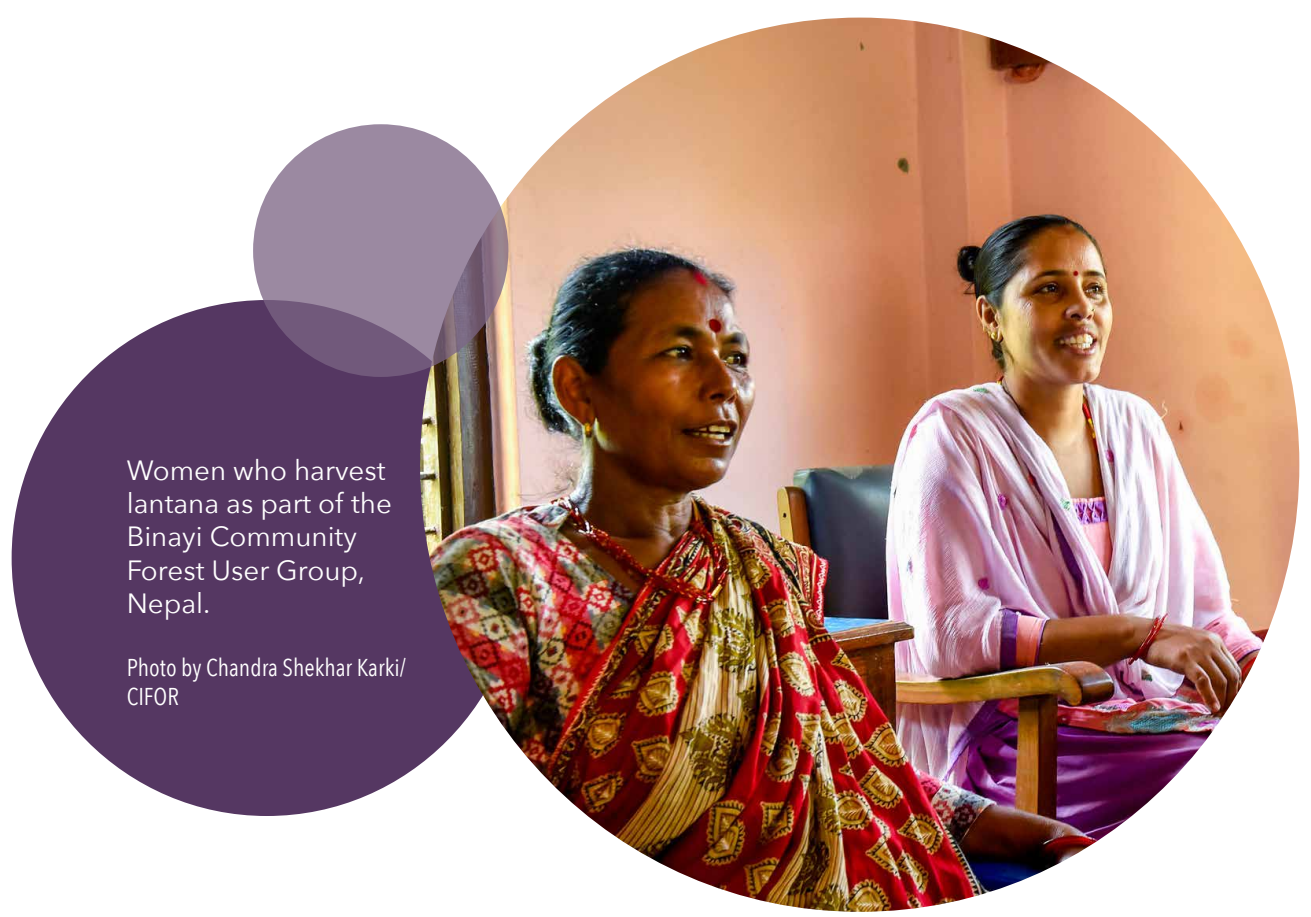

on Sustainable Palm Oil and prompted renewed attention to the gender responsiveness of its criteria, indicators and guidance (Sijapati Basnett et al. 2016). Fairtrade Foundation is drawing on recommendations from FTA's work on Fairtrade ${ }^{65}$ (Gallagher et al. 2020) to better guide and measure gender-transformative change in the context of Fairtrade standards, strategies and projects.

\section{Challenges along the way}

Truly integrating gender across the FTA portfolio, breaking down barriers, and enhancing interdisciplinary collaboration to solve the complex challenges that FTA seeks to address has been an ongoing challenge, requiring continuous time and effort. As FTA scientists have stated, the presence of gender specialists in international environmental, development, and research organizations does not necessarily ensure their influence or result in a reorientation of the sustainability debate in terms of commitments to promote equality and justice (Arora-Jonsson and Sijapati Basnett 2018). In the areas of environmental management and agriculture where FTA operates, the natural sciences and their paradigms (concepts, research methods, theories, and postulates) dominate, and they typically give greater value to biophysical aspects than the social sciences. Attempts to address gender often

${ }^{65}$ https://www.fairtrade.org.uk/media-centre/news/new-fairtrade-study-highlights-successes-and-ways-forward-towardsgender-equality/ 
remain technical and superficial rather than involving the deep engagement and meaningful analysis that are needed to generate transformative change (Elmhirst et al. 2020). FTA has sought to go beyond these shortcomings in gender mainstreaming towards a genuine recognition and influence of gender in its research, in order to stimulate profound and lasting change for greater equality. In this regard, in addition to strengthening capacities, FTA's gender team worked with scientists from various research traditions to have them recognize and engage with the diversity of human experiences and with marginalization in their work. Some scientists met this process, which requires open-mindedness and reflexivity, with hesitation and resistance. The continuous presence of gender on the agenda of the CRP's leaders; constant interactions with gender team members and other colleagues championing gender research; the availability of resources to support gender research; and the demonstrated value of FTA's gender research over time has encouraged scientists to engage, and has contributed to shifts in the mindsets of even some of the most resistant scientists.

In comparison to other CRPs, the CGIAR-IEA $(2017,78)$ Evaluation of Gender in CGIAR noted that FTA was "exceptional in having a very large pool of 'other' social scientists working on gender," including a number of men scientists. Yet, large in comparison does not mean large in absolute terms of number of gender specialists working across FTA, as gender expertise in research teams was generally one-person deep, if that, and unevenly distributed across FPs and FTA managing partners. Engaging with the complexity and context-specific nature of gender-power relations in projects requires dedicated time and capacities, which was in relatively short supply for a research program of FTA's size. Given this context, the many resources that FTA has produced to support gender integration in forestry/natural resource management research is particularly noteworthy. It highlights the value of the substantial continued investment of FTA program-level funding to that critical dimension of FTA work.

Elmhirst et al. (2020) identify several challenges related to integrating gender meaningfully in FTA and in other environment and development programmes and organizations. One such challenge is the slow pace of social change, especially when measured against the short timelines of project funding and the high donor demand for rapid outcomes. The 10-year horizon of FTA has been critical for transcending some of the constraints associated with the program's shorter-term projects and advancing both strands detailed

\footnotetext{
${ }^{65}$ https://www.fairtrade.org.uk/media-centre/news/new-fairtrade-study-highlights-successes-and-ways-forward-towardsgender-equality/
} 
in FTA's Gender Strategy (CIFOR 2013d) and revised research agenda and action plan (CGIAR FTA 2020). Creating a strong and integrated gender team across FTA centres, enhancing capacities, and fostering an enabling environment for gender research, amid a turnover of FTA scientists, requires continuous investment (in time and monetary resources). Likewise, developing FTA's strong external partnerships and coalitions, some initiated through serendipitous encounters, required years of collaboration built incrementally, with occasional breakthroughs in influence and funding. Developing the empirical evidence that would solidify these partnerships, and FTA's reputation and influence, was a long-term endeavour, as was being able to make and demonstrate change on the ground. As the FTA program ends, the challenge ahead is to capitalize on its momentum and achievements to drive the next generation of gender research to enhance equality and inclusion in forest and agroforestry landscapes.

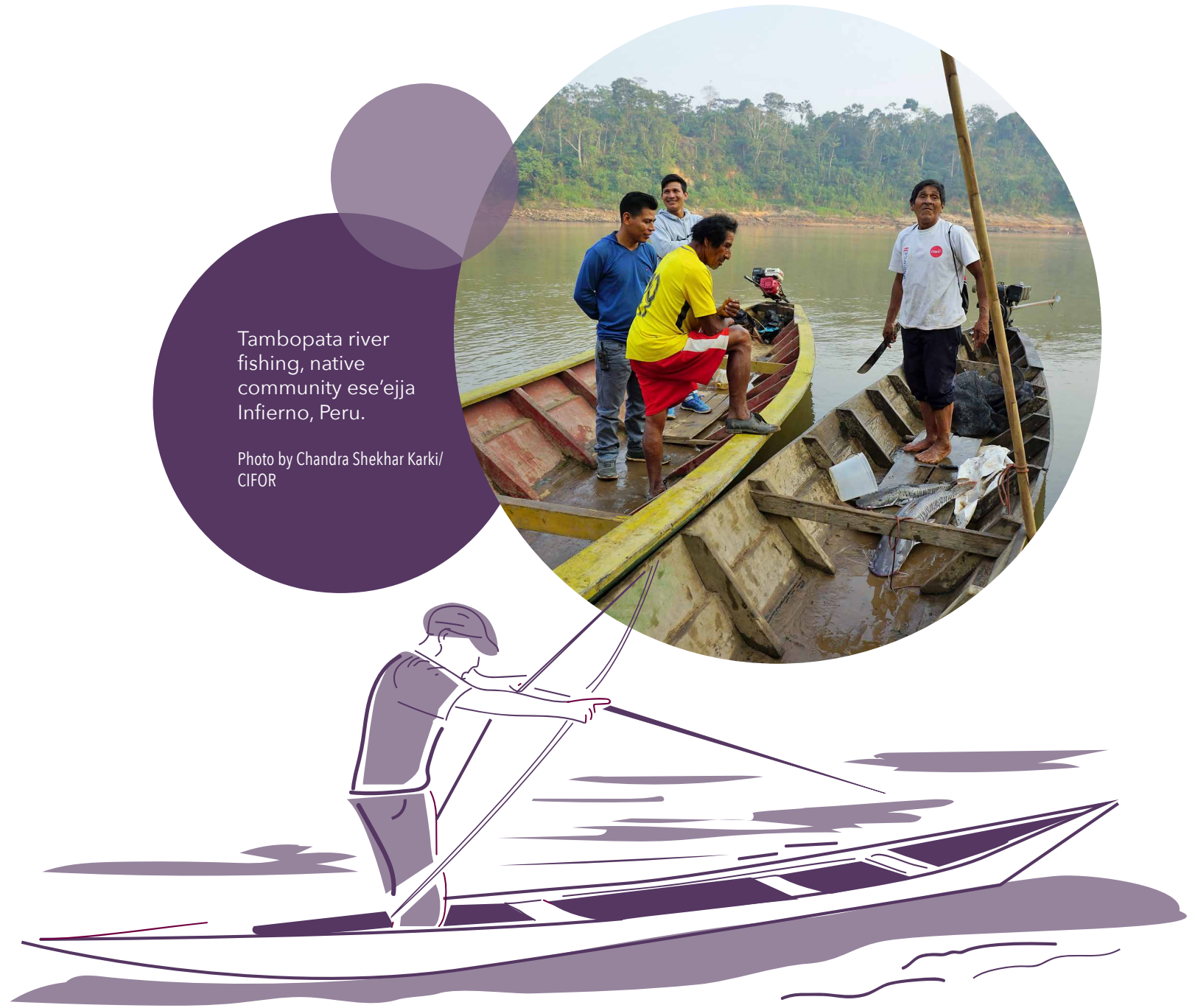




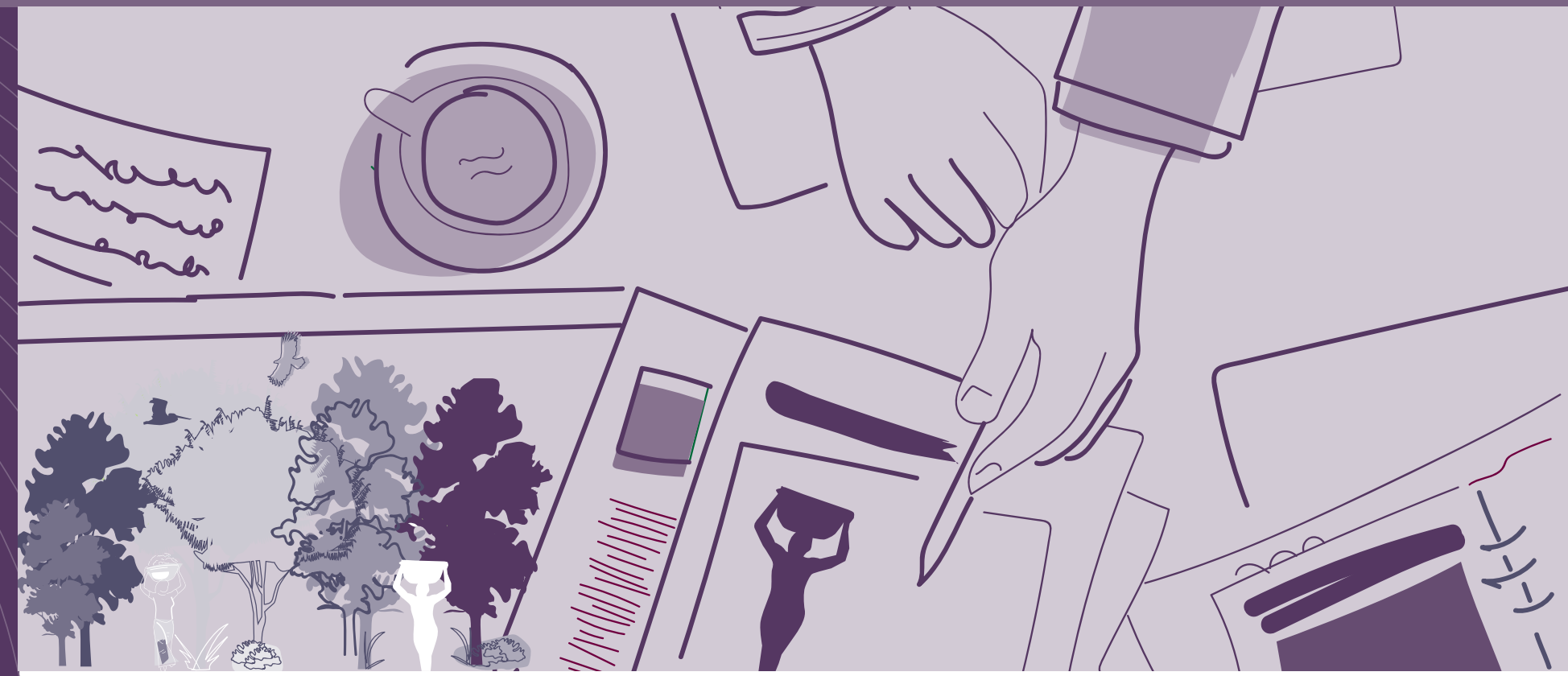

\section{Moving forward}

Among its recommendations, the final CGIAR Advisory Services Shared Secretariat Evaluation of FTA (CAS Secretariat 2020, 3) mentions gender as one of the "emerging and global issues" to which "FTA should continue [making] scientific contributions." FTA has set a path for continuing to advance gender integration and research in landscapes experiencing rapid rural transformations. Future research on tomorrow's landscapes should continue to address this rapid pace of rural change, including the various effects ${ }^{66}$ of migration ${ }^{67}$ and livelihood diversification among rural women and men, and aspirations among young men and women in forest landscapes that are different than those in the past (Kawarazuka et al. 2020; Mulyoutami et al. 2020; Simelton et al. 2021). FTA's work on gender and migration has begun to identify the types of policies, institutional arrangements and interventions that foster enabling contexts for women and men from different generational groups ${ }^{68}$ to benefit from migration, ${ }^{69}$ mobility and livelihoods of people who live in multiple places in forested landscapes, and the links between migration, aspirations and rural innovation and investments (Juniwaty et al. 2019; Crossland et al. 2021b). Comparative research on migration ${ }^{70}$ has shown that migration plays a key role in influencing the

\footnotetext{
${ }^{66} \mathrm{https}: / /$ www.youtube.com/watch?app=desktop\&v=DBrUEITjnGc

${ }^{67} \mathrm{https}$ // / www.foreststreesagroforestry.org/news-article/impact-of-migration-on-people-and-landscapes-in-nepal/?utm_ source $=$ October $\% 202018 \& u t m \_$campaign $=$FTA $\% 20$ NEWS $\% 20$ UPDATE\&utm_medium $=$ website

${ }^{68} \mathrm{https}$ // / forestsnews.cifor.org/52018/left-behind-the-women-and-elderly-of-nalma?fnl=en

${ }^{69} \mathrm{https}$ // / forestsnews.cifor.org/42192/unpacking-migration-and-gender-in-nepals-community-forests?fnl=en
} 


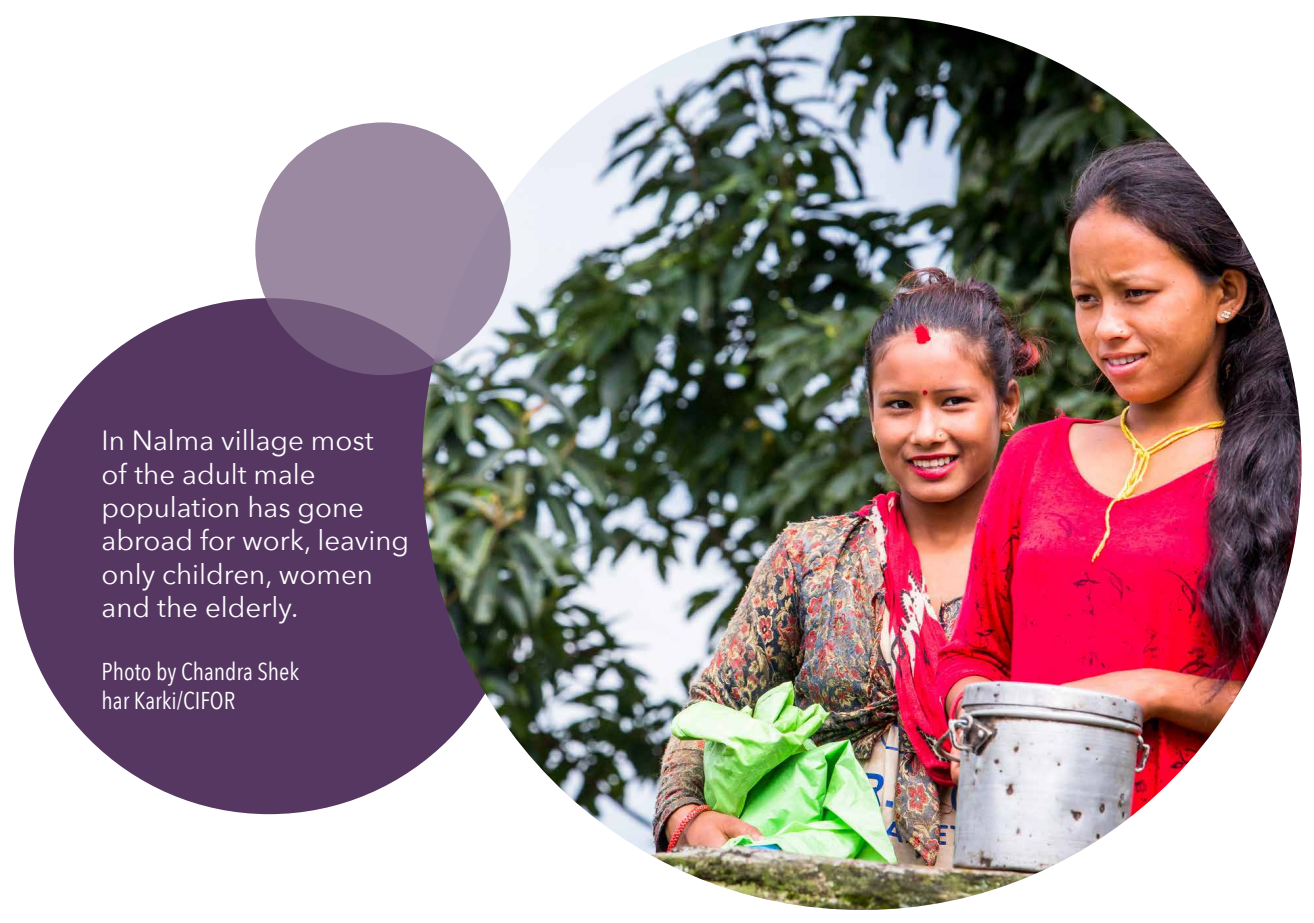

composition and use of forests (Hecht et al. 2015; Sijapati Basnett 2016). Further work is needed to examine the availability and reliability of data on forests and migration from a gender perspective, and to obtain additional quantitative and qualitative data.

The engagement of FTA gender researchers in high-level processes related to the Convention on Biological Diversity's (CBD) post-2020 Global Biodiversity Framework, the UN Decade on Ecosystem Restoration, and the Global Environment Facility's expert group on gender has demonstrated an increasing emphasis on achieving synergies among a range of environmental targets and among environmental and gender equality goals. This has led to FTA gender-focused work exploring synergies and trade-offs among such goals, as well as strategies and approaches that support the achievement of mutual benefits (Djoudi et al. 2013; Arora-Jonsson et al. 2019; Sijapati Basnett et al. 2019; Elias et al. 2020b). This work has generated considerable interest among multilateral conventions and organizations, exemplified by an ongoing collaboration with UN Women for a paper on achieving synergies across the Rio Conventions from a gender perspective. Based on evidence gathered over years of FTA research, further work on trade-offs and synergies is needed to strengthen the business case for gender equality and advance this goal through environmental agendas. 
Yet, as FTA has argued, advancing gender equality should not be contingent on the value of equality to achieve other forest and environmental goals. FTA's recognition that gender equality has intrinsic value (i.e. value in its own right) leads to the understanding that reconciling gender equality and environmental objectives may at times be required (CGIAR FTA 2020). FTA's commitment to gender equality, and its work on rights-based approaches, which takes gender equality as an inherent human right, should be accelerated to inform debates and policies in this field (Larson et al. 2019b; Monterroso et al. 2019). Efforts are now underway to use these approaches in multi-stakeholder partnerships to advance the social inclusion of underrepresented groups, in particular women and Indigenous Peoples (Sarmiento-Barletti 2020b; Evans et al. 2021).

Likewise, more research is needed to address the root causes of inequality, including norms that discriminate against women and other marginalized groups. In its commentary of the FTA Phase 2 proposal, ${ }^{71}$ the Independent Science and Partnership Council (ISPC 2015, 3) commends FTA's "renewed focus on transformative gender research." FTA's foundational work on norms (Elias et al. 2018b) and gender transformative approaches ${ }^{72}$ - and its current six-country comparative study co-funded by IFAD on gender transformative approaches to advance women's land rights - can lead the way for future research in this area. Moreover, FTA's trailblazing work on masculinities explores how men and boys experience gender-specific forms of vulnerabilities in the context of rural transformations, including a book that challenges biases and perceptions of forestry and agroforestry as masculine domains (Colfer 2020), can pave the way towards notions of "constructive masculinities"73 in research and development.

In the current context of COVID-19 and of rapid climate change, future research should build on FTA's work on gender and resilience (Djoudi and Brockhaus 2011; Paez Valencia 2021) and on rural women's lives amid the pandemic ${ }^{74}$ to build forward better and support more inclusive forest and agroforest landscapes. Ongoing FTA research in Vietnam is investigating the impact of payments for ecosystem services (PES) and REDD+ schemes on forest communities' resilience in the face of COVID-19. The research community should continue to fill critical evidence gaps in information on equitable natural resource management institutions (both

\footnotetext{
${ }^{71}$ https://www.foreststreesagroforestry.org/forests-trees-and-agroforestry-landscapes-livelihoods-and-governance/

${ }^{72}$ http://blog.worldagroforestry.org/index.php/2018/12/21/challenging-gender-norms-around-trees-and-land-restorationin-west-africa-can-research-be-transformative/

${ }^{73}$ https://gender.cgiar.org/news-events/striking-new-tune-gender-researchers-re-examine-their-focus-men

${ }^{74}$ https://alliancebioversityciat.org/stories/burkina-faso-rural-womens-perspectives-covid-19
} 
formal and informal) that can enable resilient livelihoods and landscapes. Such an ambitious research agenda can help unlock solutions to the many environmental and socio-economic crises that humanity faces, to advance sustainable development and embed justice in the fabric of society.

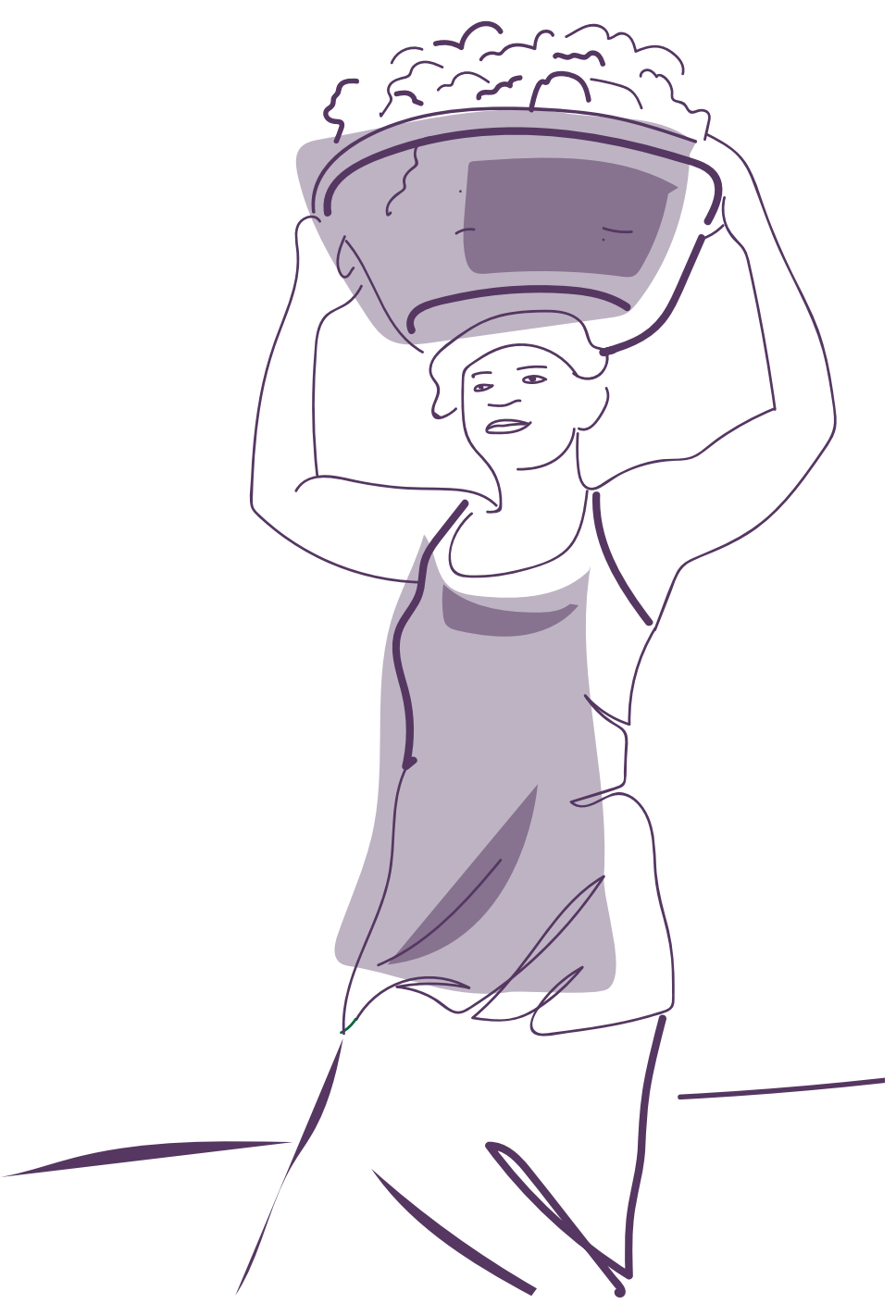




\section{References}

Armbruster S, Solomon J, Blare T and Donovan J. 2019. Women's time use and implications for participation in cacao value chains: evidence from VRAEM, Peru. Development in Practice 29(7):827-843. https:/ / doi.org/10.1080/09614524.2019.1604630.

Arora-Jonsson S, Agarwal S, Pierce Colfer C, Keene S, Kurian P and Larson A. 2019. SDG 5: Gender Equality - A Precondition for Sustainable Forestry. In Katila P, Pierce Colfer C, De Jong W, Galloway G, Pacheco P and Winkel G. eds. Sustainable Development Goals: Their Impacts on Forests and People. Cambridge, UK: Cambridge University Press, 146-177. https://doi.org/10.1017/9781108765015.007.

Arora-Jonsson S and Sijapati Basnett B. 2018. Disciplining gender in environmental organizations: The texts and practices of gender mainstreaming. Gender, Work \& Organization 25(3):309-325. https://doi.org/10.1111/gwao.12195.

Arwida SD, Maharani CD, Sijapati Basnett B and Yang AL. 2017. Gender-relevant considerations for developing REDD+ indicators: Lessons learned for Indonesia. CIFOR Info Brief No. 168. Bogor: CIFOR. https://doi.org/10.17528/CIFOR/006398.

Asfaw A, Lemenih M, Kassa H and Ewnetu Z. 2013. Importance, determinants and gender dimensions of forest income in eastern highlands of Ethiopia: The case of communities around Jelo Afromontane forest. Forest Policy and Economics 28:1-7. https://doi.org/10.1016/j.forpol.2013.01.005.

Asher K. 2016. Tenure vs. Territory: Black Women's Struggles in the Pacific Lowlands of Colombia. In Colfer CJP, Sijapati Basnett B and Elias M. eds. Gender and Forests: Climate Change, Tenure, Value Chains and Emerging Issues. New York: Routledge, 206-218.

Asher K and Shattuck A. 2017. Forests and Food Security: What's Gender Got to Do with It? Social Sciences 6(1), 34. https://doi.org/10.3390/socsci6010034.

Asher K and Sijapati Basnett B. 2016. Gender equality as an entitlement: An assessment of the UN Women's Report on Gender Equality and Sustainable Development 2014. Development and Change 47(4):952-964. https:/ / doi.org/10.1111/dech.12248.

Asher K and Varley G. 2018. Gender in the jungle: A critical assessment of women and gender in current (2014-2016) forestry research. International Forestry Review 20(2):149-159. https://doi.org/10.1505/146554818823767537.

Atmadja S, Lestari H, Djoudi H, Liswanti N and Tamara A. 2020a. Making climate finance work for women and the poor: Insights from national climate finance mechanisms in Indonesia. Bogor: CIFOR. https://doi.org/10.17528/cifor/007871.

Atmadja S, Liswanti N, Tamara A, Lestari H and Djoudi H. 2020b. Leveraging climate finance for gender equality and poverty reduction: A comparative study. Bogor: CIFOR.

https://doi.org/10.17528/cifor/007889. 
Badstue LB, Elias M, Kommerell V, Petesch P, Prain G, Pyburn R and Umantseva A. 2020. Making room for manoeuvre: Addressing gender norms to strengthen the enabling environment for agricultural innovation. Development in Practice 30(4):541-547.

https://doi.org/10.1080/09614524.2020.1757624.

Badstue LB, Lopez DE, Umantseva A, Williams GJ, Elias M, Farnworth CR, Rietveld A, Njuguna-Mungai E, Luis J, Najjar D, et al. 2018a. What drives capacity to innovate? Insights from women and men small-scale farmers in Africa, Asia, and Latin America. Fournal of Gender, Agriculture and Food Security 1(3):54-81. https://doi.org/10.19268/JGAFS.312018.3.

Badstue LB, Petesch P, Feldman S, Prain G, Elias M and Kantor P. 2018b. Qualitative, comparative, and collaborative research at large scale: An introduction to GENNOVATE. Fournal of Gender, Agriculture and Food Security 1(3):1-27.

https://doi.org/10.19268/JGAFS.312018.1

Banana, AY, Bukenya, M, Arinaitwe, E, Birabwa, B and Ssekindi, S. 2012. Gender, tenure and community forests in Uganda. CIFOR Working Paper No. 87. Bogor, Indonesia: CIFOR. https://doi.org/10.17528/cifor/003778.

Basilio C and Fernandez M. 2014. Management and use of forest landscapes: Unpacking gendered knowledge and skills using participatory methods in forest genetic resources research, 8-12 July 2013, Taoundé, Cameroon. Workshop Report. Rome, Italy: Bioversity International; Paris: International Support Group (ISG). https://hdl.handle.net/ 10568/104542.

Bee BA and Sijapati Basnett B. 2017. Engendering social and environmental safeguards in REDD+: Lessons from feminist and development research. Third World Quarterly 38(4):787-804. https://doi.org/10.1080/01436597.2016.1191342.

Bioversity International, CARE International, CCAFS, CIFOR, Global Greengrants Fund, IUGN, UN Women, UNDP-UNEP Poverty Environment Initiative and WEDO. 2015. Gender and Climate Change: Evidence and Experience. Set of Briefs. Bogor, Indonesia: CIFOR. https://www.cifor.org/knowledge/publication/5933/.

Blare T and Donovan J. 2017. Intensification of cocoa in the Peruvian Amazon: Gender relations and options for deeper engagement by women. ICCO, Simposio Internacional de Investigación sobre el Cacao. Lima, Peru November 13-17, 2017.

Blare T and Useche, P. 2015. Is there a choice? Choice experiment to determine the value men and women place on cacao agroforests in coastal Ecuador. International Forestry Review 17(4): 46-60. Special Issue on Gender in Forestry. https://doi.org/10.1505/146554815816086390.

Bose P. 2017. Land tenure and forest rights of rural and indigenous women in Latin America: Empirical evidence. Women's Studies International Forum 65:1-8. https://doi.org/10.1016/j.wsif.2017.10.006.

Bose P. 2015. India's drylands agroforestry: A ten-year analysis of gender and social diversity, tenure and climate variability. International Forestry Review 17(4): 85-98. https://doi.org/10.1505/146554815816086435. 
Bose P. 2013. Individual tenure rights, citizenship and conflicts: Outcomes from tribal India's forest governance. Forest Policy and Economics 33:71-79. https://doi.org/10.1016/j.forpol.2012.09.016.

Bose P, Larson AM, Lastarria-Cornhiel S, Radel C, Schmink M, Schmook B and Vázquez-García V. 2017. Women's rights to land and communal forest tenure: A way forward for research and policy agenda in Latin America. Women's Studies International Forum 65:53-59. https://doi.org/10.1016/j.wsif.2017.10.005.

Bose P and Savyasashi. eds. 2014. Landscaping Actually: Forests to Farms through a Gender Lens. Photo book. Cali (Colombia): International Centre for Tropical Agriculture (CIAT). https://issuu.com/ciat-ftagender/docs/final_ebook.

Bourgeois R, Liswanti N, Zamora A, Mukasa C, Herawati T, Monterroso I, Mshale B, Banjade MB, Mwangi E and Larson A. 2017. Guide for co-elaboration of scenarios: Facilitating future-oriented shared understanding and joint action in the context of forest tenure reforms and tenure security. Bogor, Indonesia: CIFOR.

Bourne M, Kimaiyo J, Tanui J, Gatacutan D and Otiende V. 2015. Can gender appreciation of trees enhance landscape multifunctionality? A case of smallholder farming systems on Mount Elgon. International Forestry Review 17(4):33-45.

https://doi.org/10.1505/146554815816086480.

Brockhaus M, Djoudi H and Locatelli B. 2013. Envisioning the future and learning from the past: Adapting to a changing environment in northern Mali. Environmental Science $\mathcal{E}$ Policy 25:94-106. https://doi.org/10.1016/j.envsci.2012.08.008.

Butali C and Wekesa A. 2018. Building farmer organisations' capacity to collectively adopt agroforestry and sustainable agriculture land management practices in Lake Victoria Basin. Lessons for gender-responsive landscape restoration. GLF Brief 9. Bonn: Global Landscapes Forum.

Carney J and Elias M. 2013. Gendered Knowledge and the African Shea Nut Tree. In Hecht S, Morrison K and Padoch C. eds. The Social Lives of Forests. London, UK and Chicago, IL: The University of Chicago Press. p. 231-238. https://doi.org/10.7208/chicago/9780226024134.001.0001.

CAS Secretariat (GGIAR Advisory Services Shared Secretariat). 2020. CGIAR Research Program 2020 Reviewes: Forests, Trees and Agroforestry. Rome: CAS Secretariat Evaluation Function. https://cas.cgiar.org/evaluation/publications/crp-2020-review-fta.

Catacutan D and Naz F. 2015. Gender roles, decision-making and challenges to agroforestry adoption in Northwest Vietnam. International Forestry Review 17(4):22-32. https://doi.org/10.1505/146554815816086381.

Catacutan D, McGaw E and Llanza MA. eds. 2014. In Equal Measure: A User Guide to Gender Analysis in Agroforestry. Los Baños, Philippines: World Agroforestry Centre (ICRAF) Southeast Asia Regional Program. https://www.worldagroforestry.org/output/equalmeasure-user-guide-gender-analysis-agroforestry. 
CGIAR FTA. 2020. Gender Equality and Social Inclusion: A Revised Agenda and Action Plan for the CGLAR Research Program on Forests, Trees and Agroforestry 2020-2021. Bogor, Indonesia: CGIAR Research Program on Forests, Trees and Agroforestry (FTA). https://doi.org/10.17528/cifor/007604.

CGIAR FTA. 2019. The Gender Equality in Research Scale (GEIRS). Bogor, Indonesia: CGIAR Research Program on Forests, Trees and Agroforestry (FTA). https://www.cifor.org/knowledge/publication/7281.

CGIAR-IEA. 2017. Evaluation of Gender in CGIAR. Volume I, Evaluation of Gender in Research. Rome, Italy: Independent Evaluation Arrangement (IEA) of CGIAR. https:// cas.cgiar.org/evaluation/publications/evaluation-gender-research-and-cgiar-workplace.

Charles Darwin University. 2019. Evaluation of gender integration in FTA. Final report. Unpublished.

Chomba S, Treue T and Sinclair F. 2015. The political economy of forest entitlements: Can community based forest management reduce vulnerability at the forest margin? Forest Policy and Economics 58:37-46. https://doi.org/10.1016/j.forpol.2014.11.011.

CIFOR. 2019. Annual Report 2018: Forests matter. Bogor, Indonesia: CIFOR. https://annualreport2018.cifor.org/.

CIFOR. 2017. Annual Report 2016: Putting forests and people on the global agenda. Bogor, Indonesia: CIFOR. https://www.cifor.org/knowledge/publication/6477.

CIFOR. 2013a. At a glance: Gender strategy for the CGIAR Research Program on Forests, Trees and Agroforestry (CRP-FTA). Bogor, Indonesia: CIFOR. https://doi.org/10.17528/cifor/004098.

CIFOR. 2013b. CIFOR Proposal Development Guidelines for Integrating Gender: Does your proposal demonstrate appropriate attention to gender issues? Bogor, Indonesia: CIFOR. [Also available in French, Spanish, and Indonesian]. https://doi.org/10.17528/cifor/004155.

CIFOR. 2013c. Gender analysis in forestry research: what policymakers should know. Bogor, Indonesia: CIFOR. https://doi.org/10.17528/cifor/004057.

CIFOR. 2013d. Gender in the CGIAR Research Program on Forests, Trees and Agroforestry: A strategy for research and action. Bogor, Indonesia: CIFOR. https://doi.org/10.17528/cifor/004056.

Clendenning J. 2019. Approaching rural young people. FTA Working Paper No. 1. Bogor, Indonesia: CGIAR Research Program on Forests, Trees and Agroforestry (FTA). https://doi.org/10.17528/cifor/007383.

Clendenning J, Elias M and Sijapati Basnett B. 2019. At the intersection of gender and generation: Engaging with 'youth' in the CGIAR Research Program on Forests, Trees and Agroforestry. Brief. Bogor, Indonesia: CGIAR Research Program on Forests, Trees and Agroforestry (FTA). https://doi.org/10.17528/cifor/007346. 
Coleman EA and Mwangi E. 2013. Women's participation in forest management: A cross-country analysis. Global Environmental Change 23(1):193-205.

https://doi.org/10.1016/j.gloenvcha.2012.10.005.

Colfer CJP. 2020. Masculinities in Forests. London, UK and New York, NY: Routledge. https://gender.cgiar.org/publications-data/masculinities-forests.

Colfer CJP. 2013. The gender box: A framework for analysing gender roles in forest management. Occasional paper 82. Bogor, Indonesia: CIFOR. https://www.researchgate.net/ publication/238455238_The_Gender_Box_A_framework_for_analysing_gender_roles_ in_forest_management.

Colfer CJP. 2005. Implications of adaptive collaborative management for more equitable forest management. In Colfer CJP. ed. The Equitable Forest: diversity, community and resource management. Washington DC and Bogor, Indonesia: Resources for the Future and The Center for International Forestry Research (CIFOR), 296-303.

https://www.cifor.org/knowledge/publication/1870/.

Colfer CJP, Achdiawan R, Adnan H, Moeliono M, Mulyana A, Mulyoutami E, Roshetko JM, Yuliani EL, Balang and LepMil. 2015a. Preparing the ground for better landscape governance: Gendered realities in southern Sulawesi. Forests, Trees and Livelihoods 24(1):5983. https://doi.org/10.1080/14728028.2014.951002.

Colfer CJP, Achdiawan R, Roshetko JM, Mulyoutami E, Yuliani L, Mulyana A, Moeliono M, Adnan H and Erni. 2015b. The Balance of Power in Household Decision-Making: Encouraging News on Gender in Southern Sulawesi. World Development 76: 147-164. https://doi.org/10.1016/j.worlddev.2015.06.008.

Colfer CJP, Basnett BS and Ihalainen M. 2018. Making sense of 'intersectionality': A manual for lovers of people and forests. Occasional Paper 184. Bogor, Indonesia: CIFOR. https://doi.org/10.17528/cifor/006793.

Colfer CJP, Catacutan D and Naz F. 2015c. Introduction: Contributions and gaps in gender and agroforestry. Forest Policy and Economics 17:1-10. https://doi.org/10.1505/146554815816002176.

Colfer CJP, Elias M and Jamnadass R. 2015d. Women and men in tropical dry forests: a preliminary review. Forest Policy and Economics 17(2):70-90. https://doi.org/10.1505/146554815815834877.

Colfer CJP, Elias M, Sijapati Basnett B and Hummel SS. 2017. The Earthscan Reader on Gender and Forests. London, UK and New York, NY: Routledge. https://www.cifor.org/knowledge/publication/6545/.

Colfer CJP, Ihalainen M and Monterroso I. 2020. Understanding gender dynamics in the context of rural transformation processes: An East Kalimantan case study. Occasional Paper 212. Bogor, Indonesia: CIFOR. https://doi.org/10.17528/cifor/007858.

Colfer CJP, Ihalainen M and Sijapati Basnett B. In press. Intersectionality. In AkramLodhi AH, Dietz H, Engels B and McKay BM. eds. Handbook of Critical Agrarian Studies. Cheltenham, UK: Edward Elgar. https://www.e-elgar.com/shop/gbp/handbook-ofcritical-agrarian-studies-9781788972451.html. 
Conroy R, Redlin F, McGovern D and Howard T. 2018. The impacts of gender-conscious payment models on the status of women engaged in micro-forestry on the Kenyan coast. Lessons for genderresponsive landscape restoration. GLF Brief No. 3. Bogor, Indonesia: CIFOR. https://www. cifor.org/knowledge/publication/7005/.

Conway D, Schulte I, Streck C, Haupt F, Bakhtary H, Mayers J and Macqueen D. 2018. Improving Governance to Protect Forests: Empowering People and Communities, Strengthening Lawes and Institutions. Progress on the New York Declaration on Forests. Goal 10 Assessment Report. Coordinated by Climate Focus with support from the Climate and Land Use Alliance. New York, NY: New York Declaration on Forests (NYDF). https://www.climatefocus. com/sites/default/files/NYDF\%20report\%202018_0.pdf.

Crenshaw K. 1989. Demarginalizing the intersection of race and sex: a black feminist critique of antidiscrimination doctrine, feminist theory and antiracist politics. University of Chicago Legal Forum 1:139-167. https://chicagounbound.uchicago.edu/cgi/viewcontent. cgi?article $=1052 \&$ context $=$ uclf.

Crossland M and Paez Valencia AM. 2020. Impact of on-farm Land Restoration Practices on the Time and Agency of Women in the Drylands of Eastern Kenya. Nairobi, Kenya: World Agroforestry Centre (ICRAF). https://hdl.handle.net/10568/111634.

Crossland M, Paez Valencia AM, Pagella T, Magaju C, Kiura E, Winowiecki L and Sinclair F. 2021a. Onto the Farm, into the Home: How Intrahousehold Gender Dynamics Shape Land Restoration in Eastern Kenya. Ecological Restoration 39(1\&2). https://www.muse.jhu.edu/article/793663.

Crossland M, Paez Valencia AM, Pagella T, Mausch K, Harris D, Dilley L and Winowiecki L. 2021b. Women's changing opportunities and aspirations amid male outmigration: insights from Makueni County, Kenya. The European Fournal of Development Research 33(4): 910-932. https://doi.org/10.1057/s41287-021-00362-8.

Cruz-Burga Z, Monterroso I, Larson AM, Valencia F and Saldaña JS. 2018. El impacto de la formalización de los derechos sobre la tierra y el bosque: Perspectivas de comunidades en Madre de Dios y Loreto. Vol. 221. Bogor, Indonesia: CIFOR. https://doi.org/10.17528/cifor/006952.

Dewi S, Janudianto and Martini E. 2013. Gender perspectives in selecting tree species (G-TreeFarm). In van Noordwijk M, Lusiana B, Leimona B, Dewi S and Wulandari D. eds. Negotiation-support toolkit for learning landscapes. Bogor, Indonesia: World Agroforestry Centre (ICRAF) Southeast Asia Regional Program, 69-74.

Degrande A and Arinloye D-DA. 2015. Gender in Agroforestry: Implications for Action-Research. Nature E Faune Fournal 29(1):6-11. https:/ /www.worldagroforestry.org/ publication/gender-agroforestry-implications-action-research.

Djoudi $\mathrm{H}$ and Brockhaus M. 2011. Is adaptation to climate change gender neutral? Lessons from communities dependent on livestock and forests in northern Mali. International Forestry Review 13(2):123-135. https://doi.org/10.1505/146554811797406606. 
Djoudi H, Brockhaus M and Locatelli B. 2013. Once there was a lake: Vulnerability to environmental changes in northern Mali. Regional Environmental Change 13:493-508. https://doi.org/10.1007/s10113-011-0262-5.

Djoudi H, Djenontin N, Dayamba D and Zida M. 2015. Is Carbon Gender Neutral? Adaptation mitigation gendered linkages in the dry forest context of Burkina Faso. CIFOR Presentation. Bogor, Indonesia: CIFOR. https://www.slideshare.net/CIFOR/is-carbon-gender-neutraladaptation-mitigation-gendered-linkages-in-the-dry-forest-context-of-burkina-faso.

Djoudi H, Locatelli B, Vaast C, Asher K, Brockhaus M and Sijapati Basnett B. 2016. Beyond dichotomies: Gender and intersecting inequalities in climate change studies. Ambio 45(3):248-262. https://doi.org/10.1007/s13280-016-0825-2.

Duguma LA, Atela J, Negassa Ayana A, Alemagi D, Mpanda M, Nyago M, Minang P, Nzyoka J, Foundjem-Tita D and Ndjebet C. 2018. Community forestry frameworks in sub-Saharan Africa and the impact on sustainable development. Ecology and Society 23(4):21. https://doi.org/10.5751/ES-10514-230421.

Durán R, Monterroso I and Larson AM. 2018. Género e interculturalidad en la formalización de las comunidades nativas en el Perú. CIFOR.

https://www.cifor.org/knowledge/publication/6916/.

Elias M. 2018. Mobilizing indigenous and local knowledge for successful restoration. Lessons for genderresponsive landscape restoration. GLF Brief 4. Bonn, Germany: Global Landscapes Forum. https://www.cifor.org/publications/pdf_files/brief/GLFBrief/ 7006-GLFBrief.pdf.

Elias M. 2017. Introduction. Partie 3. Savoirs et agrobiodiversité. In Guétat-Bernard H and Saussey M. eds. Genre, et savoirs : Pratiques in innovations rurales au Sud. Paris, France: IRD, 203-212. https://books.openedition.org/irdeditions/9154?lang=en.

Elias M. 2016. Distinct, shared and complementary: gendered agroecological knowledge in review. CAB Reviewes 11(40):1-16. https://doi.org/10.1079/PAVSNNR201611040.

Elias M. 2015. Gender, knowledge-sharing and management of shea (Vitellaria paradoxa) parklands in central-west Burkina Faso. Fournal of Rural Studies 38:27-38. https:// doi. org/10.1016/j.jrurstud.2015.01.006.

Elias M. 2013a. Practical Tips for Conducting Gender-responsive Data Collection. Rome, Italy: Bioversity International. [Also available in French and Spanish]. https://www. bioversityinternational.org/e-library/publications/detail/practical-tips-for-conductinggender-responsive-data-collection/.

Elias M. 2013b. Tips for Asking Gender-responsive Questions. Rome, Italy:

Bioversity International. [Also available in French and Spanish]. https://www. bioversityinternational.org/e-library/publications/detail/tips-for-asking-genderresponsive-questions/.

Elias M and Arora-Jonsson S. 2017. Negotiating across difference: Gendered exclusions and cooperation in the shea value chain. Environment and Planning D: Society and Space 35(1):107-125. https://doi.org/10.1177/0263775816657084. 
Elias M and Fernandez M. 2014. Genre, biodiversité et agriculture familiale. Pour 222(2):285-293. https://doi.org/10.3917/pour.222.0285.

Elias M and Hermanowicz E. 2016. Practical tips for communicating findings in a gender-responsive way. Rome, Italy: Bioversity International. https://www.bioversityinternational.org/elibrary/publications/detail/practical-tips-for-communicating-research-findings-in-agender-responsive-way/.

Elias M and Morgan M. 2016. Mixing methods for holistic project evaluations: Revisiting Nepal's home garden project through a qualitative lens. Bioversity International Impact Assessment Brief No.18. Rome, Italy: Bioversity International. https://www.bioversityinternational.org/elibrary/publications/detail/mixing-methods-for-holistic-project-evaluations-revisitingnepals-home-garden-project-through-a-qu/.

Elias M, Badstue L, Farnworth CR, Prain G, van der Burg M, Petesch P, Elmhirst R, Bullock R, Feldman S, Jafry T, et al. 2018a. Fostering collaboration in cross-CGIAR research projects and platforms: Lessons from the GENNOVATE initiative. GENNOVATE resources for scientists and research teams. CDMX, Mexico: CIMMYT. https://gennovate.org/wpcontent/uploads/2018/10/FOSTERING_COLLABORATION_Gennovate_Tool.pdf.

Elias M, Elmirst R, Ibraeva G, Sijapati Basnett B, Ablezova M and Siscawati M. 2018b. Understanding Gendered Innovation Processes in Forest-based Landscapes: Case studies from Indonesia and Kyrgyz Republic. GENNOVATE Report to the CGIAR Research Programs on Forests, Trees and Agroforestry (FTA). Rome, Italy: Biodiversity International.

https://www.cifor.org/knowledge/publication/6951.

Elias M, Grosse A and Campbell N. 2020a. Unpacking 'gender' in India's Joint Forest Management Program: lessons from two Indian states. Geoforum 111:218-228. https://doi.org/10.1016/j.geoforum.2020.02.020.

Elias M, Hummel SS, Sijapati Basnett B and Colfer CJP. 2017a. Gender bias affects forests worldwide. Ethnobiology Letters 8(1):31-34. https://doi.org/10.14237/ebl.8.1.2017.834.

Elias M, Jalonen R, Fernandez M and Grosse A. 2017b. Gender-responsive participatory research for social learning and sustainable forest management. Forests, Trees and Livelihoods 26(1):1-12. https://doi.org/10.1080/14728028.2016.1247753.

Elias M, Joshi D and Meinzen-Dick R. 2021. Restoration for Whom, by Whom? A Feminist Political Ecology of Restoration. Ecological Restoration 39(1\&2). https://doi.org/10.3368/er.39.1-2.3.

Elias M, Mudege N, Lopez DE, Najjar D, Kandiwa V, Luis J, Yila J, Tegbaru A, Ibrahim G, Badstue LB, et al. 2018c. Gendered aspirations and occupations among rural youth, in agriculture and beyond: A cross-regional perspective. Fournal of Gender, Agriculture and Food Security 1(3):82-107. https://doi.org/10.19268/JGAFS.312018.4.

Elias M, Sijapati Basnett B and De Pryck J. 2020b. Tackling Gender Inequality through Forest-Related Policies and Programmes: Global Challenges, Multi-scale Innovations and Local Experiences. In Nikolakis W and Innes J. eds. The Wicked Problem of Forest Policy: A Multidisciplinary Approach to Sustainability in Forest Landscapes. Cambridge, UK: Cambridge University Press, 167-196. https://doi.org/10.1017/9781108684439.006. 
Elias M, Yan CK and Fernandez M. 2014. Gender research fellowship program inception workshop, 15-19 August 2013, Kuching, Malaysia. Workshop report. Rome, Italy: Bioversity International. https://www.bioversityinternational.org/e-library/publications/detail/ gender-research-fellowship-programme-inception-workshop-15-19-august-2013-kuchingmalaysia-works/.

Elmhirst R, Resurrección BP and Elias M. 2020. Embodied engagement with gender and agrobiodiversity: Leveraging transformative moments in multidisciplinary teams. In Elmhirst R and Resurrección BP. eds. Negotiating Gender Expertise in Environment and Development. London, UK: Routledge. pp. 115-130.

https://hdl.handle.net/10568/110915.

Elmhirst R, Siscawati M, Sijapati Basnett B and Ekowati D. 2017. Gender and generation in engagements with oil palm in East Kalimantan, Indonesia: Insights from feminist political ecology. The Fournal of Peasant Studies 44(6):1135-1157.

https://doi.org/10.1080/03066150.2017.1337002.

Equal Measures 2030. 2018. Data Driving Change: Introducing the EM2030 SDG Gender Index. Woking, UK: Equal Measures 2030. https://data.em2030.org/wp-content/ uploads/2018/09/EM2030-2018-Global-Report.pdf.

Evans K, Guariguata MR and Brancalion PHS. 2018. Participatory monitoring to connect local and global priorities for forest restoration. Conservation Biology 32(3):525-534. https://doi.org/10.1111/cobi.13110.

Evans K, Flores S, Larson AM, Marchena R, Müller P and Pikitle A. 2017. Challenges for women's participation in communal forests: Experience from Nicaragua's indigenous territories. Women's Studies International Forum 65:37-46.

https://doi.org/10.1016/j.wsif.2016.08.004.

Evans K, Larson AM and Flores S. 2020. Learning to learn in tropical forests: training field teams in adaptive collaborative management, monitoring and gender. International Forestry Review 22(2):189-198. https://doi.org/10.1505/146554820829403504.

Evans K, Larson AM, Mwangi E, Cronkleton P, Maravanyika T, Hernandez X, Müller P, Pikitle A, Marchena R, Mukasa C, et al. 2014. Field guide to Adaptive Collaborative Management and improving women's participation. Bogor, Indonesia: GIFOR. [Also available in Spanish]. https://doi.org/10.17528/cifor/005085.

Evans K, Monterroso I, Ombogoh DB, Liswanti N, Tamara A, Mariño H, Sarmiento JP and Larson AM. 2021. Getting it right: A guide to improve inclusion in multi-stakeholder forums. Bogor, Indonesia: CIFOR. https://doi.org/10.17528/cifor/007973.

FAO, IFAD and WFP. 2020. Gender transformative approaches for food security, improved nutrition and sustainable agriculture - A compendium of fifteen good practices. Rome, Italy: Food and Agriculture Organization of the United Nations (FAO).

https://doi.org/10.4060/cb1331en.

Faridah Aini M, Elias M, Lamers H, Shariah U, Brooke P and Mohd Hafizul H. 2017. Evaluating the usefulness and ease of use of participatory tools for forestry and livelihoods research in Sarawak, Malaysia. Forests, Trees and Livelihoods 26(1):29-46.

https://doi.org/10.1080/14728028.2016.1246213. 
Gallagher EJ. 2016. Gendered dimensions of large-scale and smallholder-inclusive agricultural investments in Tanzania. Bogor, Indonesia: CIFOR.

https://www.cifor.org/knowledge/publication/6273.

Gallagher EJ, Monterroso I and Sanjaya IM. 2020. Women's access, equity and empowerment: Progress and uptake of the Fairtrade Gender Strategy 2016-2020. Bogor, Indonesia: CIFOR. https://www.fairtrade.net/library/womens-access-equity-and-empowerment-study.

Gautier D, Dessard H, Djoudi H, Gazull L and Soumaré M. 2020. Savannah gendered transition: how woodlands dynamics and changes in fuelwood delivery influence economic autonomy in Mali. Environment, Development and Sustainability 22(4): 3097-3117. https://doi.org/10.1007/s10668-019-00336-1.

Gélinas N, Lavoie A, Labrecque MF and Olivier A. 2015. Linking women, trees and sheep in Mali. Forest Policy and Economics 17(4):76-84.

https://doi.org/10.1505/146554815816086462.

Guariguata MR, Atmadja S, Baral H, Boissière M, Brady M, Chomba S, Cronkleton P, Djoudi H, Duchelle A, Duguma L, et al. 2021. Forest and Landscape Restoration. FTA Highlights of a Decade 2011-2021 series. Bogor, Indonesia: The CGIAR Research Program on Forests, Trees and Agroforestry (FTA).

Gumucio T, Alves MDA, Orentlicher N and Hernández Ceballos MC. 2018. Analysis of gender research on forest, tree and agroforestry value chains in Latin America. Forests, Trees and Livelihoods 27(2):69-85. https://doi.org/10.1080/14728028.2017.1417921.

Gumucio T, Hurtado JJ, Lundy M and Mosquera EE. 2016a. LINK Methodology: Gender Responsive Manual. Cali, Colombia: International Center for Tropical Agriculture (CIAT). 48 pp. https://hdl.handle.net/10568/80679.

Gumucio T, Mora Benard MA, Clavijo M, Hernández MC, Tafur M and Twyman J. 2015. Silvopastoral systems in Latin America: Mitigation opportunities for men and women livestock producers. Copenhagen: GGIAR Research Program on Climate Change, Agriculture and Food Security (CGAFS). https://hdl.handle.net/10568/69151.

Gumucio T, Twyman J and Clavijo M. 2017. Gendered perspectives of trees on farms in Nicaragua: Considerations for agroforestry, coffee cultivation, and climate change. Working Paper. CIAT Publication No.432. Cali, Colombia: International Center for Tropical Agriculture (CIAT); GGIAR Research Program on Climate Change, Agriculture and Food Security (CCAFS); CGIAR Research Program on Forests, Trees and Agroforestry (FTA). https://core.ac.uk/download/pdf/132687784.pdf.

Gumucio T, Yore H, Mello D and Loucel C. 2016b. Coffee and cocoa value chains: Gender dynamics in Peru and Nicaragua. Working paper. Cali, Colombia: International Center for Tropical Agriculture (CIAT). https://hdl.handle.net/10568/78670.

Gutiérrez Velásquez C. 2016. Determinación de medios y estrategias de vida, nutrición rural y uso de agro biodiversidad con enfoque de género para el desarrollo sostenible en cuatro comunidades del municipio de Waslala, región autónoma del Atlántico Norte, Nicaragua. Master's thesis. Turrialba, Costa Rica: Centro Agronómico Tropical de Investigación y Enseñanza (CATIE).

http://repositorio.bibliotecaorton.catie.ac.cr/handle/11554/8595. 
Hajjar R, Newton P, Ihalainen M, Agrawal A, Gabay M, Alix-Garcia J, Brown SE, Erbaugh JT, Hughes K, Mawutor S, et al. 2020. Levers for Alleviating Poverty in Forests and Tree-Based Systems. In Miller DC, Mansourian S and Wildburger C. eds. Forests, Trees and the Eradication of Poverty: Potential and Limitations. Vienna, Austria: International Union of Forest Research Organizations (IUFRO), 125-174. https://www.cifor.org/knowledge/publication/7828.

Haverhals M, Ingram V, Elias M and Sijapati Basnett B. 2014. Gender and forest, tree and agroforestry value chains. Bogor, Indonesia: CIFOR.

https://www.cifor.org/knowledge/publication/5497/.

Hecht S, Yang AL, Sijapati Basnett B, Padoch C and Peluso NL. 2015. People in Motion, Forests in Transition: trends in migration, urbanization, and remittances and their effects on tropical forests. Occasional Paper 142. Bogor, Indonesia: CIFOR.

https://www.cifor.org/publications/pdf_files/OccPapers/OP-142.pdf.

Hegde N, Elias M, Lamers HAH and Hegde M. 2017. Engaging local communities in social learning for inclusive management of native fruit trees in the Central Western Ghats, India. Forests, Trees and Livelihoods 26(1):65-83.

https://doi.org/10.1080/14728028.2016.1257398.

IFAD. 2019. Creating opportunities for rural youth. 2019 Rural Development Report. Rome, Italy: International Fund for Agricultural Development (IFAD). https://www.ifad.org/en/ web/knowledge/-/publication/2019-rural-development-report.

Ihalainen M. 2018. Landscape Restoration in Kenya: Addressing gender equality. Nairobi, Kenya: Kenya Forest Service. https://www.cifor.org/knowledge/publication/7012/.

Ihalainen M, Schure J and Sola P. 2020. Where are the women? A review and conceptual framework for addressing gender equity in charcoal value chains in Sub-Saharan Africa. Energy for Sustainable Development 55:1-12. https://doi.org/10.1016/j.esd.2019.11.003.

Ihalainen M, Sijapati Basnett B, Larson AM, Duchelle AE, Pham TT and Djoudi H. 2017. What should be included in the Green Climate Fund's new Gender Policy and Action Plan? Lessons from CIFOR's research and analysis. CIFOR Info Brief No. 179. Bogor, Indonesia: CIFOR. https://doi.org/10.17528/cifor/006541.

IIX (Impact Investment Exchange). 2021. Financing gender empowering green growth in Indonesia: Case studies on innovative financing mechanisms. IIX (Impact Investment Exchange), The Center for International Forestry Research (CIFOR) and Tropenbos International.

https://hdl.handle.net/10568/114453.

Ingram V, Haverhals M, Petersen S, Elias M, Sijapati Basnett B and Phosiso S. 2016. Gender and forest, tree and agroforestry value chains: Evidence from literature. In Colfer CJP, Sijapati Basnett B and Elias M. eds. Gender and Forests: Climate Change, Tenure, Value Chains and Emerging Issues. New York, NY: Routledge, 221-242.

https://www.cifor.org/knowledge/publication/6090/. 
Ingram V, Schure J, Tieguhong JC, Ndoye O, Awono A and Iponga DM. 2014. Gender implications of forest product value chains in the Congo basin. Forests, Trees and Livelihoods 23(1-2):67-86. https://doi.org/10.1080/14728028.2014.887610.

ISPC (Independent Science and Partnership Council). 2015. Commentary on the FTA Phase II Preproposal (2017-2022). Montpellier, France: CGIAR Independent Science and Partnership Council (ISPC). https://cas.cgiar.org/index.php/isdc/publications/ispccommentary-fta-phase-ii-preproposal-2017-2022.

ISPC (Independent Science and Partnership Council). 2011. ISPC Commentary on the CRP-6 Proposal (dated Feb 2011): Forests Trees and Agroforestry: Livelihoods, Landscapes and Governance. Working paper. Montpellier, France: CGIAR Independent Science and Partnership Council (ISPC). https://hdl.handle.net/10947/2581.

Jalonen R, Lamers H and Elias M. 2018. Guidelines for Equitable and Sustainable NonTimber Forest Product Management. Rome, Italy: Bioversity International. https://www. bioversityinternational.org/fileadmin/user_upload/Guidelines_Marlene_2018.pdf.

Jhaveri NJ, with Monterroso I and Larson AM. eds. 2020. Forest Tenure Pathways to Gender Equality: A practitioner's guide. Bogor, Indonesia: CIFOR. https://doi.org/10.17528/cifor/007909.

Juniwaty KS, Sijapati Basnett B, Thung PH, Sanjaya IM and Busra MI. 2019. Connecting the dots in the forest-migration nexus: A case study from Malinau, Indonesia. Working Paper 250. Bogor, Indonesia: CIFOR. https://doi.org/10.17528/cifor/007306.

Kakungulu Z. 2018. Role of capital in enhancing participation of women in commercial forestry: A case study of the Sawlog Production Grant Scheme (SPGS) project in Uganda. Lessons for genderresponsive landscape restoration. GLF Brief 2. Bogor, Indonesia: CIFOR. https://www.cifor.org/knowledge/publication/7004/.

Karambiri M, Elias M, Vinceti B and Grosse A. 2017. Exploring local knowledge and preferences for shea (Vitellaria paradoxa) ethnovarieties in Southwest Burkina Faso through a gender and ethnic lens. Forests, Trees and Livelihoods 26(1):13-28. https://doi.org/10.1080/14728028.2016.1236708.

Kawarazuka N, Duong TM and Simelton E. 2020. Gender, labor migration and changes in small-scale farming on Vietnam's north-central coast. Critical Asian Studies 52(4):550564. https://doi.org/10.1080/14672715.2020.1815229.

Kiptot E. 2015. Gender roles, responsibilities, and spaces: Implications for agroforestry research and development in Africa. Forest Policy and Economics 17(4):11-21. https://doi.org/10.1505/146554815816086426.

Kiptot E, Franzel S and Degrande A. 2014. Gender, agroforestry and food security in Africa. Current Opinion in Environmental Sustainability 6:104-109. https://doi.org/10.1016/j.cosust.2013.10.019. 
Koffi CK, Djoudi H and Gautier D. 2017. Landscape diversity and associated coping strategies during food shortage periods: evidence from the Sudano-Sahelian region of Burkina Faso. Regional Environmental Change 17(5):1369-1380.

https://doi.org/10.1007/s10113-016-0945-z.

Kristjanson P, Siegmann K, Afif Z, Manchester K and Gurung J. 2018a. Enhancing effectiveness of forest landscape programs through gender-responsive actions. Lessons for gender-responsive landscape restoration. GLF Brief 1. Bogor, Indonesia: GIFOR.

https://www.cifor.org/publications/pdf_files/brief/GLFBrief/7003-GLFBrief.pdf.

Kristjanson P, Siegmann K, Afif Z, Manchester K, Gurung J, Kakungulu Z, Conroy R, Redlin F, McGovern D, Howard T, et al. 2018b. Joint infobrief set on gender equality and forest landscape restoration. Bonn, Germany: Global Landscapes Forum. https://www. globallandscapesforum.org/publication/joint-infobrief-set-on-gender-equality-and-forestlandscape-restoration/.

Larson AM, Dokken T and Duchelle AE. 2014. Can safeguards guarantee gender equity? Lessons from research on women in early REDD+ implementation. REDD+ Safeguards Brief 4. Bogor, Indonesia: CIFOR. https://doi.org/10.17528/cifor/005191.

Larson AM, Dokken T, Duchelle AE, Atmadja S, Resosudarmo IAP, Cronkleton P, Cromberg M, Sunderlin W, Awono A and Selaya G. 2015. The role of women in early REDD+ implementation: Lessons for future engagement. Forest Policy and Economics 17(1):43-65. https://doi.org/10.1505/146554815814725031.

Larson AM, Monterroso I and Cantuarias P. 2019a. Gender and the formalization of native communities in the Peruvian Amazon. CIFOR Info Brief No. 238. Bogor, Indonesia: CIFOR. [Also available in Spanish]. https://doi.org/10.17528/cifor/007108.

Larson AM, Monterroso I and Cronkleton P. 2018a. Collective titling in the Peruvian Amazon: A history in three acts. Bogor, Indonesia: CIFOR. [Also available in Spanish]. https://www.cifor.org/knowledge/publication/7014/.

Larson AM, Monterroso I, Liswanti N, Herawati T, Banana AY, Canturias P, Rivera K and Mwangi E. 2019b. Models for formalizing customary and community forest lands: The need to integrate livelihoods into rights and forest conservation goals. Bogor, Indonesia: CIFOR. [Also available in Spanish and Indonesian]. https://doi.org/10.17528/cifor/007273.

Larson AM, Solis D, Duchelle AE, Atmadja S, Resosudarmo IAP, Dokken T and Komalasari M. 2018b. Gender lessons for climate initiatives: A comparative study of REDD+ impacts on subjective wellbeing. World Development 108:86-102. https://doi.org/10.1016/j.worlddev.2018.02.027.

Lastarria-Cornhiel S, Villaseñor V, Barahona Z and Orti L. 2017. Gender empowerment in the Gran Chaco. Women's Studies International Forum 65:9-16.

https://doi.org/10.1016/j.wsif.2016.11.009.

Li TM. 2015. Social impacts of oil palm in Indonesia: A gendered perspective from West Kalimantan. CIFOR Occasional Paper No. 124. Bogor, Indonesia: CIFOR. https://doi.org/10.17528/cifor/005579. 
Liswanti N, Tamara A and Djoudi H. 2020. Climate finance and gender on the ground Insights from mitigation and adaptation interventions in Indonesia. CIFOR Info Brief No. 306. https://www.cifor.org/publications/pdf_files/infobrief/7857-infobrief.pdf

Mai YH, Mwangi E and Wan M. 2012. Gender analysis in forestry research: Looking back and thinking ahead. CIFOR Info Brief No. 51. Bogor, Indonesia: CIFOR. https://gender.cgiar. org/publications-data/gender-analysis-forestry-research-looking-back-and-thinkingahead.

Mai YH, Mwangi E and Wan M. 2011. Gender analysis in forestry research: Looking back and thinking ahead. Forest Policy and Economics 13(2):205-219. https://doi.org/10.1505/146554811797406589.

Manfre C and Rubin D. 2012. Integrating Gender into Forestry Research: A Guide for CIFOR Scientists and Programme Administrators. Bogor, Indonesia: CIFOR. https://doi.org/10.17528/cifor/003892.

Mansourian S. 2021. Disciplines, Sectors, Motivations and Power Relations in Forest Landscape Restoration. Ecological Restoration 39(1): 16-26.

https://www.muse.jhu.edu/article/793656.

Martius $\mathrm{C}$ and Duchelle A. In press. REDD+: Combating Climate Change with Forest Science. FTA Highlights of a Decade 2011-2021 series. Bogor, Indonesia: The GGIAR Research Program on Forests, Trees and Agroforestry (FTA).

Mathez-Stiefel SL. 2016. Local knowledge and valuation of agroforestry practices and species for climate change adaptation in the Peruvian Andes. In Davidson-Hunt LJ, Suich H, Meijer SS and Olsen N. eds. People in Nature: Valuing the diversity of interrelationships between people and nature. Gland, Switzerland: IUCN (International Union for Conservation of Nature), 32-33. https://www.worldagroforestry.org/publication/local-knowledge-andvaluation-agroforestry-practices-and-species-climate-change.

Mathez-Stiefel SL, Ayquipa-Valenzuela J, Corrales-Quispe R, Rosales-Richard L and Valdivia-Díaz M. 2016. Identifying gender-sensitive agroforestry options: Methodological considerations from the field. Mountain Research and Development 36(4):417-430.

https:/ / www.worldagroforestry.org/publication/identifying-gender-sensitive-agroforestryoptions-methodological-considerations-field.

Maukonen P, Donn P and Snook LK. 2020. Addressing potential conflict using participatory mapping: Collection of forest foods from timber trees around industrial concessions in Cameroon. Frontiers in Forests and Global Change 3:72.

https://doi.org/10.3389/ffgc.2020.00072.

Mausch K, Harris D, Dilley L, Crossland M, Pagella T, Yim J and Jones E. 2021. Not all about farming: Understanding aspirations can challenge assumptions about rural development. The European Fournal of Development Research 15:1-24.

https://doi.org/10.1057/S41287-021-00398-W.

Mbosso C, Degrande A, Van Damme P, Tsafack S, Nimino G and Tchoundjeu Z. 2015. Gender differences in knowledge, perception and use of the Ricinodendron heudelotii 
(Baill. Pierre ex pax) kernel extraction machine. Forest Policy and Economics 17(4):124-134. https://doi.org/10.1505/146554815816086417.

McDougall CL, Leeuwis G, Bhattarai T, Maharjan MR and Jiggins J. 2013. Engaging women and the poor: Adaptive collaborative governance of community forests in Nepal. Agriculture and Human Values 30(4):569-585. https://doi.org/10.1007/S10460-013-9434-X.

Mello D and Schmink M. 2017. Amazon entrepreneurs: Women's economic empowerment and the potential for more sustainable land use practices. Women's Studies International Forum 65:28-36. https://doi.org/10.1016/j.wsif.2016.11.008.

Meybeck A, et al. In press. Adaptation to Climate Change. FTA Highlights of a Decade 2011-2021 series. Bogor, Indonesia: The CGIAR Research Program on Forests, Trees and Agroforestry (FTA).

Monterroso I and Larson AM. 2018a. Challenges in formalizing the rights of native communities in Peru. CIFOR Info Brief No. 231. Bogor, Indonesia: CIFOR. [Also available in Spanish]. https://doi.org/10.17528/cifor/006294.

Monterroso I and Larson AM. 2018b. Progress in formalizing "native community" rights in the Peruvian Amazon (2014-2018). CIFOR Info Brief No. 233. Bogor, Indonesia: CIFOR. [Also available in Spanish].https://doi.org/10.17528/cifor/007080.

Monterroso I, Larson AM, Mwangi E, Liswanti N and Cruz-Burga Z. 2019. Mobilizing Change for Women Within Collective Tenure Regimes. Resource Equity.

https://www.cifor.org/knowledge/publication/7440/.

Monterroso I, Larson AM, QuaedvliegJ, Valencia F, Jarama L and Saldaña JS. 2018. Formalization of the collective rights of native communities in Peru: The perspective of implementing officials. CIFOR Info Brief No. 247. Bogor, Indonesia: CIFOR. [Also available in Spanish]. https://doi.org/10.17528/cifor/007271.

Mukasa C and Tibazalika A. 2018. Enhancing Women's Participation in Forestry Management Using Adaptive Collaborative Management: The Case of Mbazzi Farmers Association, Mpigi District, Uganda. Lessons for gender-responsive landscape restoration. GLF Brief 6. Bogor, Indonesia: CIFOR. https://www.cifor.org/knowledge/publication/7008/.

Mukasa C, Tibazalika A, Mango A and Nabirye Muloki H. 2013. Gender and forestry in Uganda: Policy, legal and institutional frameworks. CIFOR Working Paper. Bogor, Indonesia: CIFOR. https://doi.org/10.17528/cifor/003795.

Mukasa C, Tibazalika A, Mwangi E, Banana AY and Evans K. 2016a. Adaptive Collaborative Management: A Simplified Guide for Practitioners. Kampala, Uganda: Association of Uganda Professional Women in Agriculture and Environment. [Also available in Luganda]. https://www.cifor.org/knowledge/publication/6339.

Mukasa C, Tibazalika A, Mwangi E, Banana AY, Bomuhangi A and Bushoborozi J. 2016b. Strengthening women's tenure rights and participation in community forestry. CIFOR Info Brief No. 155. Bogor, Indonesia: CIFOR. https://doi.org/10.17528/cifor/006249. 
Mulyoutami E, Catacutan D, Martini E, Khususiyah N, Janudianto N, Villamor GB and van Noordwijk M. 2013. Gender roles in land use and value chains (GRoLUV). In van Noordwijk M, Lusiana B, Leimona B, Dewi S and Wulandari D. eds. Negotiation support toolkit for learning landscapes. Bogor, Indonesia: World Agroforestry Centre (ICRAF) Southeast Asia Regional Program, 55-60. http://www.asb.cgiar.org/Publications\%20 2014/Books/Negotiation\%20support\%20tool\%20kit.pdf.

Mulyoutami E, Lusiana B and van Noordwijk M. 2020. Gendered Migration and Agroforestry in Indonesia: Livelihoods, Labor, Know-How, Networks. Land 9(12):529. https://doi.org/10.3390/land9120529.

Mulyoutami E, Roshetko JM, Martini E and Awalina D. 2015. Gender roles and knowledge in plant species selection and domestication: A case study in South and Southeast Sulawesi. Forest Policy and Economics 17(4):99-111. https://doi.org/10.1505/146554815816086453.

Narváez Guerrero, I. 2014. Desarrollo de una propuesta del bio-protocolo de consulta y consentimiento libre, previo e informado con el pueblo indígena Sauni Arungka, etnia Mayangna. Master's thesis. Turrialba, Costa Rica: Centro Agronómico Tropical de Investigación y Enseñanza (CATIE). http://hdl.handle.net/11554/7168.

Nchanji YK, Levang P and Jalonen R. 2017. Learning to select and apply qualitative and participatory methods in natural resource management research: Self-critical assessment of research in Cameroon. Forests, Trees and Livelihoods 26(1):47-64.

https://doi.org/10.1080/14728028.2016.1246980.

Newton P, Kinzer AT, Miller DC, Oldekop JA and Agrawal A. 2020. The number and spatial distribution of forest-proximate people globally. One Earth 3(3):363-370.

https://doi.org/10.1016/J.ONEEAR.2020.08.016.

Nijbroek R and Wangui E. 2018. What women and men want: Considering gender for successful, sustainable land management programs: Lessons learned from the Nairobi Water Fund. Lessons for gender-responsive landscape restoration. GLF Brief 7. Bonn, Germany: Global Landscapes Forum. https://www.globallandscapesforum.org/publication/what-women-and-menwant-considering-gender-for-successful-sustainable-land-management-programs-lessonslearned-from-the-nairobi-water-fund/.

Njenga M, Karanja N, Munster C, Iiyama M, Neufeldt H, Kithinji J and Jamnadass R. 2013. Charcoal production and strategies to enhance its sustainability in Kenya. Development in Practice 23(3):359-371. https://doi.org/10.1080/09614524.2013.780529.

Nsita SA, Nakangu B, Banana AY, Mshale B, Mwangi E and Ojwang D. 2017. Forest tenure reform implementation in Uganda: Current challenges and future opportunities. Bogor, Indonesia: CIFOR. https://www.cifor.org/knowledge/publication/7520/.

NYDF (New York Declaration on Forests). 2018. Improving Governance to Protect Forests: Empowering People and Communities, Strengthening Lawes and Institutions. Progress on the New York Declaration on Forests. Goal 10 Assessment Report. Coordinated by Climate Focus with support from the Climate and Land Use Alliance. Briefing Paper. New York, NY: New York Declaration on Forests (NYDF). https://forestdeclaration.org/images/uploads/ resource/2018_Goal10_FocusReport_Brief.pdf. 
Paez AM, Ihalainen M, Elias M and Sijapati Basnett B. 2019. The Gender Equality in Research Scale (GEIRS): A tool for monitoring and encouraging progress on gender integration in research for and in development. Brief. Bogor, Indonesia: CGIAR Research Program on Forests, Trees and Agroforestry (FTA).

https://www.cifor.org/publications/pdf_files/FTA/Briefs/7270-FTABrief.pdf.

Paez Valencia AM. 2021. Gender-responsive project implementation within the Resilient Food Systems Programme. Guidance Note. Resilient Food Systems Cross Cutting Series 02. Nairobi, Kenya: World Agroforestry Centre (ICRAF). https://www.resilientfoodsystems.co/assets/ resources/pdf/rfs_gender-activities-and-guidelines_29_01_21.pdf.

Paez Valencia AM and Crossland M. 2018. Understanding landscape restoration options in Kenya: Risks and opportunities for advancing gender equality. Lessons for gender-responsive landscape restoration. GLF Brief 8. Bogor, Indonesia: CIFOR. https://www.cifor.org/knowledge/publication/7010/.

Pehou C, Djoudi H, Vinceti B and Elias M. 2020. Intersecting and dynamic gender rights to néré, a food tree species in Burkina Faso. Fournal of Rural Studies 76:230-239. https://doi.org/10.1016/j.jrurstud.2020.02.011.

Petesch P, Badstue L, Prain G, Elias M and Tegbaru A. 2017. Entry points for enabling gender equality in agricultural and environmental innovation. GENNOVATE resources for scientists and research teams. CDMX, Mexico: International Maize and Wheat Improvement Center (CIMMYT). https://hdl.handle.net/10568/89809.

Petesch P, Feldman S, Elias M, Badstue L, Najjar D, Rietveld A, Bullock R, Kawarazuka $\mathrm{N}$ and Luis J. 2018. Community typology framed by normative climate for agricultural innovation, empowerment, and poverty reduction. Fournal of Gender, Agriculture and Food Security 1(3):131-157. https://doi.org/10.19268/JGAFS.312018.6.

Pham TT and Brockhaus M. 2015. Gender mainstreaming in REDD+ and PES: Lessons learned from Vietnam. Gender Climate Brief No. 5. Bogor, Indonesia: CIFOR. https://www.cifor.org/knowledge/publication/5900/.

Pham TT, Mai YH, Moeliono M and Brockhaus M. 2016. Women's participation in REDD+ national decision-making in Vietnam. Forest Policy and Economics 18(3):334-344. https://doi.org/10.1505/146554816819501691.

Pouliot M and Elias M. 2013. To process or not to process? Factors enabling and constraining shea butter production and income in Burkina Faso. Geoforum 50:211-220.

Prabhu R, Golfer CJP, Diaw C, McDougall C and Fisher R. 2009. Action research with local forest users and managers: Lessons from CIFOR's research on adaptive collaborative management. In Scoones I and Thompson J. eds. Farmer First Revisited: Innovation for agricultural research and development, 66-70.

https://www.cifor.org/knowledge/publication/2824/.

Radel C, Schmook B, Haenn N and Green L. 2017. The gender dynamics of conditional cash transfers and smallholder farming in Calakmul, Mexico. Women's Studies International Forum 65:17-27. https://doi.org/10.1016/j.wsif.2016.06.004. 
Ramos C, Paez Valencia AM and Blare T. 2019. Gender Perspectives on Cocoa Production in Ecuador and Peru: Insights for Inclusive and Sustainable Intensification. Policy Brief No 44. Nairobi, Kenya: World Agroforestry. https://www.worldagroforestry.org/publication/genderperspectives-cocoa-production-ecuador-and-peru-insights-inclusive-and.

Rodríguez Cortés AM and Ospina Rojas DF. 2016. Construcción participativa de estrategias de desarrollo sostenible bajo cambio climatico en el territorio Macizo de Peñas Blancas, Nicaragua. Master's thesis. Turrialba, Costa Rica: Centro Agronómico Tropical de Investigación y Enseñanza (CATIE). http://hdl.handle.net/11554/8564.

Rosman Hernández JS. 2017. Sistematización del proceso de la gobernanza de la propiedad comunal en los territorios de Wangki Twi Tasba Raya y AMASAU, Región Autónoma de la Costa Caribe Norte, Nicaragua. Master's thesis. Turrialba, Costa Rica: Centro Agronómico Tropical de Investigación y Enseñanza (CATIE). http://hdl.handle.net/11554/8666.

Rousseau K, Gautier D and Wardell DA. 2019. Socio-economic differentiation and shea globalization in western Burkina Faso: integrating gender politics and agrarian change. The Journal of Peasant Studies 46(4):747-766.

https://doi.org/10.1080/03066150.2017.1401612.

Rubin D with Basnett B, Elias M, Bose P, Fernandez M and Mwangi E. 2013. Workshop Report, Workshop on integrating gender into the Sentinel Landscapes in the CRP FTA, 1-2 July 2013, Bogor, Indonesia. Bogor, Indonesia: CIFOR. https://www.cifor.org/ fileadmin/subsites/CRP/workshop/PDF/Workshop_Report.pdf.

Sarmiento Barletti JP, Larson AM, Hewlett C and Delgado D. 2020a. Designing for engagement: a Realist Synthesis Review of how context affects the outcomes of multistakeholder forums on land use and/or land-use change. World Development 127: 104753. https://doi.org/10.1016/j.worlddev.2019.104753.

Sarmiento Barletti JP, Mariño Saavedra HS, Bustamante de Almenara M, Aguilar Alvarado NB, Canales Poma SM and Larson AM. 2020b. ¿Cómo vamos?' Una herramienta para reflexionar sobre la participación de las mujeres indígenas u originarias en la gestión y gobernanza de sus territorios. Organización Nacional de Mujeres Indígenas Andinas y Amazónicas del Perú (ONAMIAP) and Centro para la Investigación Forestal Internacional (CIFOR). https://www.cifor.org/knowledge/publication/7883.

Sen A, Unnikrishnan H and Nagendra H. 2021. Restoration of Urban Water Commons: Navigating Social-Ecological Fault Lines and Inequities. Ecological Restoration 39(1): 120129. https://www.muse.jhu.edu/article/793665.

Shackleton S, Paumgarten F, Kassa H, Husselman M, Zida M, Purnomo H, Harini Irawati R, Fauzan AU and Melati. 2012. Forests: Gender and value chains. Bogor, Indonesia: CIFOR. https://doi.org/10.17528/cifor/003752.

Sigman E and Elias M. 2021. Three Approaches to Restoration and Their Implications for Social Inclusion. Ecological Restoration 39(1): 27-35. https://www.muse.jhu.edu/ article/793657. 
Sijapati Basnett B. 2018. UN Women's evaluation of gender in the SDGs: What's the role for the CGLAR? Bogor, Indonesia: CIFOR. https://doi.org/10.17528/cifor/007001.

Sijapati Basnett B. 2016. Gender, migration and forest governance: Re-thinking community forestry policies in Nepal. In Colfer GJP, Sijapati Basnett B and Elias M. eds. 2016. Gender and Forests: Climate Change, Tenure, Value Chains and Emerging Issues. New York, NY: Routledge, 283-299. https://www.cifor.org/knowledge/publication/6093/.

Sijapati Basnett B. 2013. Taking migration seriously: What are the implications for gender and community forestry? Bogor, Indonesia: CIFOR. https://doi.org/10.17528/cifor/004183.

Sijapati Basnett B, Elias M, Ihalainen M and Paez Valencia AM. 2017. Gender Matters in Forest Landscape Restoration: A framework for design and evaluation. Bogor: CIFOR. https: / / www.cifor.org/knowledge/publication/6685/.

Sijapati Basnett B, Gnych S and Anandi CAM. 2016. Transforming the Roundtable on Sustainable Palm Oil for greater gender equality and women's empowerment. CIFOR Info Brief No. 166. Bogor, Indonesia: GIFOR. https://doi.org/10.17528/cifor/006383.

Sijapati Basnett B, Myers R and Elias M. 2019. SDG 10: Reduced inequalities - an environmental justice perspective on implications for forests and people. In Katila P, Colfer CJP, De Jong W, Galloway G, Pacheco P and Winkel G. eds. Sustainable Development Goals: Their Impacts on Forests and People. Cambridge, UK: Cambridge University Press, 315-348. https://doi.org/10.1017/9781108765015.012.

Siles J and Prebble M. 2018. Gender-responsive Restoration Opportunities Assessment Methodology (ROAM): Engendering national forest landscape restoration assessments. Lessons for gender-responsive landscape restoration. GLF Brief 5. Bogor, Indonesia: CIFOR.

https://www.cifor.org/knowledge/publication/7007/.

Simelton E, Duong TM and Houzer E. 2021. When the "Strong Arms" Leave the Farms - Migration, Gender Roles and Risk Reduction in Vietnam. Sustainability 13(7):4081. https://doi.org/10.3390/su13074081.

Singh R, Shelar K, Duraisami M, Anderson W and Gautam RS. 2021. Equitable and inclusive landscape restoration planning: learning from a restoration opportunity assessment in India. Ecological Restoration 39(1): 108-119. https:/ /www.muse.jhu.edu/ article/793664.

Sithole P and Byakika S. 2020. Gender Analysis - Phase II: Dutch-Sino East Africa Bamboo Development Programme. Beijing (China): International Bamboo and Rattan Association (INBAR). https://www.inbar.int/project/sino-east-africa-bamboo-developmentprogramme-phase-ii/.

Stoian D, Donovan J, Elias M and Blare T. 2018a. Fit for purpose? A review of guides for gender-equitable value chain development. Development in Practice 28(4):494-509. https://doi.org/10.1080/09614524.2018.1447550.

Stoian D, Rodas A, Butler M, Monterroso I and Hodgdon B. 2018b. Forest concessions in Petén, Guatemala: A systematic analysis of the socioeconomic performance of community enterprises in the Maya Biosphere Reserve. Bogor, Indonesia: CIFOR. https://www.cifor.org/knowledge/publication/7163/. 
Su Y, Bisht S, Wilkes A, Pradhan NS, Zou Y, Liu S and Hyde K. 2017. Gendered responses to drought in Yunnan Province, China. Mountain Research and Development 37(1):24-34. https://worldagroforestry.org/publication/gendered-responses-droughtyunnan-province-china.

Sunderland T, Achdiawan R, Angelsen A, Babigumira R, Ickowitz A, Paumgarten F, Reyes-García V and Shively G. 2014. Challenging perceptions about men, women, and forest product use: A global comparative study. World Development 64 (Supplement 1):S56S66. https://doi.org/10.1016/j.worlddev.2014.03.003.

Tavenner K. 2018. Women's hidden harvest: Indigenous vegetables and amaXhosa cultural survival in Hobeni Village, South Africa. Rome, Italy: Bioversity International. https://hdl.handle.net/10568/97653.

Thull D, Elias M and Fernandez M. 2015. Bioversity International's Gender Research Fellowship Programme: results and ways forward. Impact Assessment Brief No. 17. Rome, Italy: Bioversity International. https://www.bioversityinternational.org/e-library/publications/detail/ bioversity-internationals-gender-research-fellowship-programme-results-and-waysforward/.

Tiendrébéogo S, Ouedraogo A, Kabore R, Zougouri S, Elias M, Traore AT, Vinceti B, Traore D and Yago-Ouattara EL. 2020. Enhancing women's rights and lives through gender-equitable restoration in Burkina Faso. ETFRN Newes 60: 179-185. https://cgspace.cgiar.org/bitstream/handle/10568/110464/Enhancing_ Tiendrebeogo_2020.pdf.

UN (United Nations). 2019. Report of the regional consultation on the post2020 global biodiversity framework for Latin America and the Caribbean, Montevideo, 14-17 May 2019. New York, NY: CBD. https://www.cbd.int/doc/ c/02cb/463a/68d6d12ff6a3c200cebc0240/post2020-ws-2019-05-02-en.pdf.

UNFCGC (United Nations Framework Convention on Climate Change). 2019. Differentiated impacts of climate change on women and men; the integration of gender considerations in climate policies, plans and actions; and progress in enhancing gender balance in national climate delegations. Synthesis report by the Secretariat. Subsidiary Body for Implementation fiftieth session, Bonn, 17-27 June 2019. Item 16 of the provisional agenda Gender and climate change. Bonn, Germany: UNFCGG.

UNFGCG (United Nations Framework Convention on Climate Change). 2018. Differentiated impacts of climate change and gender-responsive climate policy and action, and policies, plans and progress in enhancing gender balance in national delegations. Workshop report by the secretariat. Subsidiary Body for Implementation forty-ninth session, Katowice, 2-8 December 2018. Item 18 of the provisional agenda Gender and climate change. Bonn, Germany: UNFGCG. https://unfccc.int/documents/183857.

UN-REDD Programme. 2011. The Business Case for Mainstreaming Gender in REDD+. Geneva, Switzerland: The United Nations Collaborative Programme on Reducing Emissions from Deforestation and Forest Degradation in Developing Countries (UNREDD). https://wedocs.unep.org/20.500.11822/9657. 
UN Women. 2019a. Report of the expert workshop to develop recommendations for possible gender elements in the post-2020 global biodiversity framework, New York, United States of America, 11-12 April 2019. New York, NY: CBD. https://www.cbd.int/doc/c/423f/ a276/206bc2751c07658af8fala4a/gb-om-2019-01-02-en.pdf.

UN Women. 2019b. Report of the open-ended working group on the post-2020 global biodiversity framework on its first meeting. First meeting Nairobi, 27-30 August 2019. New York, NY: CBD. https://www.cbd.int/meetings/WG2020-01.

UN Women. 2019c. Towards a gender-responsive post-2020 global biodiversity framework: Considerations for gender mainstreaming. Open-ended working group on the post-2020 global biodiversity framework. First meeting Nairobi, 27-30 August 2019. New York, NY: CBD. https://www.cbd.int/doc/c/8386/a64b/e06e2ffa458062ca33875216/wg2020-01-inf-01en.pdf.

UN Women. 2018a. Towards a gender-responsive implementation of The Convention on Biological Diversity. In Fourteenth Meeting of the Conference of the Parties to the Convention on Biological Diversity CBD/COP/14/INF (Vol. 21). New York, NY: United Nations Entity for Gender Equality and the Empowerment of Women (UN Women). https://www.cbd. int/doc/c/34b8/2445/f3c7ee9df40a841577c51638/cop-14-inf-21-en.pdf.

UN Women. 2018b. Towards a gender-responsive implementation of The Convention on Biological Diversity. Research Paper. New York, NY: United Nations Entity for Gender Equality and the Empowerment of Women (UN Women). https://www.cifor.org/knowledge/publication/7135/.

van Noordwijk M, Mulia R and Dewi S. 2013. Ecological corridors (ECor): A distributed population model with gender specificity. In van Noordwijk M, Lusiana B, Leimona B, Dewi S and Wulandari D. eds. Negotiation support toolkit for learning landscapes. Bogor, Indonesia: World Agroforestry Centre (ICRAF) Southeast Asia Regional Program. p. 194-196.

Vázquez-García V and Ortega-Ortega T. 2017. Gender, local governance and non timber forest products. The use and management of Satureja macrostema in Oaxaca's central valleys, Mexico. Women's Studies International Forum 65:47-52. https://doi.org/10.1016/j.wsif.2016.08.003.

Villamor GB. 2014. Gender, land use and role-play games. In Catacutan D, McGaw E and Llanza MA. eds. In Equal Measure: A User Guide to Gender Analysis in Agroforestry. Los Baños, Philippines: World Agroforestry Centre (ICRAF) Southeast Asia Regional Program, 85-92. https://www.worldagroforestry.org/publication/gender-land-use-androle-playing-games.

Villamor GB, Akiefnawati R, van Noordwijk M, Desrianti F and Pradhan U. 2015. Land use change and shifts in gender roles in central Sumatra, Indonesia. Forest Policy and Economics 17(4):61-75. https://doi.org/10.1505/146554815816002211.

Villamor GB, Catacutan DC, Van Anh TT and Thi LD. 2017. Tree-cover transition in Northern Vietnam from a gender-specific land-use preferences perspective. Land Use Policy 61:53-62. https://doi.org/10.1016/j.landusepol.2016.11.002. 
Villamor GB, Desrianti F, Akiefnawati R, Amaruzaman S and van Noordwijk M. 2013. Gender influences decisions to change land use practices in the tropical forest margins of Jambi, Indonesia. Mitigation and Adaptation Strategies for Global Change 19(6):733-755. https://doi.org/10.1007/s11027-013-9478-7.

Villamor GB, van Noordwijk M, Djanibekov U, Chiong-Javier ME and Catacutan D. 2014. Gender differences in land-use decisions: shaping multifunctional landscapes? Current Opinion in Environmental Sustainability 6:128-133. https://doi.org/10.1016/j.cosust.2013.11.015.

Villamor GB, Van Noordwijk M, Troitzsch KG and Vlek PL. 2012. Human Decision Making in Empirical Agent-Based Models: Pitfalls and Caveats for Land-Use Change Policies. Conference paper. In Troitzsch KG, Möhring M and Lotzmann U. eds. ECMS 2012 Proceedings. European Council for Modeling and Simulation, 631-637. https://doi.org/10.7148/2012-0631-0637.

White B. 2019. Rural Youth, Today and Tomorrow. IFAD Research Series 48. Rome, Italy: International Fund for Agricultural Development (IFAD). https://www.ifad.org/en/web/ knowledge/-/publication/research-series-issue-48-rural-youth-today-and-tomorrow. 


\section{The FTA Highlights series}

1. Introduction: Ten Years of Forests, Trees and Agroforestry Research in Partnership for Sustainable Development

2. Tree Seed and Seedling Systems for Resilience and Productivity

3. Conservation of Tree Biodiversity and Sustainable Forest Management

4. Forest and Landscape Restoration

5. Food Security and Nutrition

6. Wild Meat

7. Trees on Farms to Improve Livelihoods and the Environment

8. Biomass, Bioenergy and Biomaterials

9. Improving Rural Livelihoods through Supporting Local Innovation at Scale

10. Sustainable Value Chains and Finance

11. REDD+: Combating Climate Change with Forest Science

12. Adaptation to Climate Change with Forests, Trees and Agroforestry

13. Multi-Functional Landscapes for Sustainable Development

14. Governing Forests, Trees and Agroforestry for Delivering on the SDGs

\section{Advancing Gender Equality and Social Inclusion}

16. Capacity Development

17. Monitoring, Evaluation, Learning and Impact Assessment

18. The Way Forward

This list represents the order of the volumes in the series and not the time sequence of publication. 



\section{Advancing Gender Equality and Social Inclusion}

The CGIAR Program on Forests, Trees and Agroforestry (FTA) has worked for the last 10 years to advance gender equality and social inclusion in diverse treed landscapes. Continuous scientific inquiry coupled with targeted efforts to constantly strengthen gender integration across the FTA research portfolio characterise this decade-long journey. This publication highlights some of the key FTA results and strategies that enabled change across scales, translating FTA's efforts into outcomes and impacts.

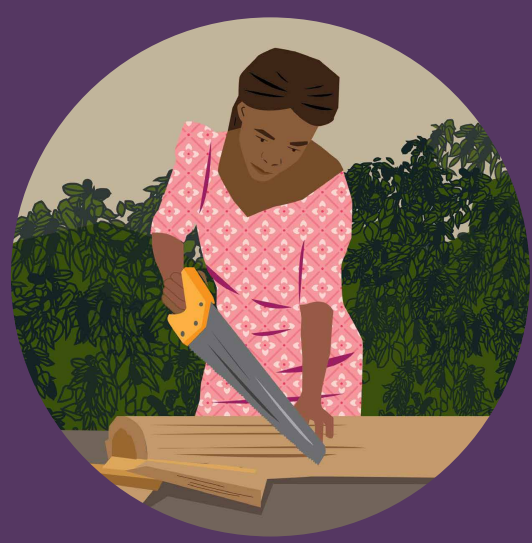

DOI: $10.17528 /$ cifor $/ 008225$

This is No.15 of the FTA Highlights of a Decade series.

Published volumes are indicated below with their illustration. Other volumes forthcoming.
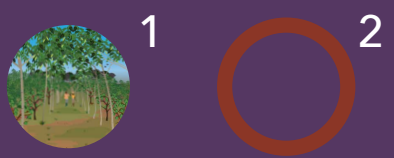

2

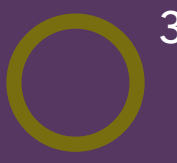

3
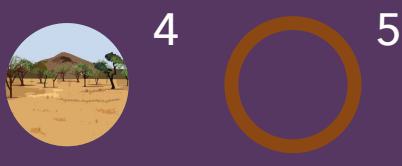

5

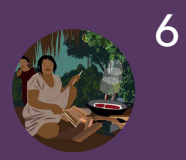

7

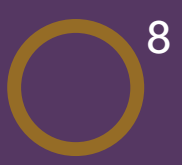

8

9

10

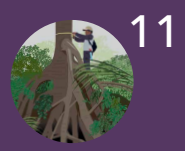

16

17
12

18 